\title{
Geometriák karakterizálása projektív-metrikus terekben
}

\author{
PhD-értekezés
}

\section{Kozma József}

Szegedi Tudományegyetem, Bolyai Intézet

Témavezető:

dr. habil Kurusa Árpád egyetemi docens

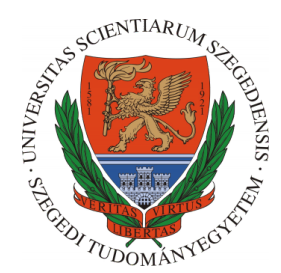

Matematika- és Számítástudományok Doktori Iskola

Szegedi Tudományegyetem, Bolyai Intézet

Szeged

2017 


\section{Tartalomjegyzék}

1 Bevezető $\quad 1$

2 Előismeretek 3

2.1 Osztóviszony és kettősviszony . . . . . . . . . . . . . . . . . . 3

2.2 Ellipszoidmetszetek és a John-Löwner-ellipszoid . . . . . . . . . . . . 5

2.3 A Minkowski-geometriákról . . . . . . . . . . . . . . . 7

2.4 A hiperbolikus geometriáról modellekkel . . . . . . . . . . . . . . . . 9

2.5 A Hilbert-geometriákról . . . . . . . . . . . . . . . . . 15

3 Elökészületek 22

3.1 Néhány technikai lemma . . . . . . . . . . . . . . . . . . . . 22

3.2 Ellipszisek egy Segre-típusú jellemzése . . . . . . . . . . . . . . . 25

3.3 Ceva típusú tétel oválisba írt háromszögekre . . . . . . . . . . . . . . 29

4 A hiperbolikus geometria karakterizációi a Hilbert-geometriák között 33

4.1 Karakterizáció Ceva- és Menelaosz-tulajdonsággal . . . . . . . . . . . 33

4.2 Karakterizáció biszektorális centrummal . . . . . . . . . . . . . . . 36

4.3 Karakterizáció ortocentrummal . . . . . . . . . . . . . . . . . . 39

5 Az euklideszi geometria karakterizációi a Minkowski-geometriák között 42

5.1 Karakterizáció jobb-biszektorális és jobb-ortocentrummal . . . . . . 42

5.2 Karakterizáció bal-biszektorális és bal-ortocentrummal . . . . . . . . 48

$\begin{array}{ll}\text { Jelölések } & 53\end{array}$

$\begin{array}{ll}\text { Hivatkozások } & 54\end{array}$

$\begin{array}{ll}\text { Köszönetnyilvánítás } & 57\end{array}$

$\begin{array}{ll}\text { Összefoglaló } & 58\end{array}$

$\begin{array}{ll}\text { Summary } & 61\end{array}$ 


\section{Bevezető}

A 20. század elsố matematikai konferenciáján David Hilbert a század matematikáját szerinte meghatározó problémák sorát vetette fel. Negyedik helyen említette a klasszikus nemeuklideszi geometriák [30] közös általánosításaként felmerüló azon geometriák meghatározását, amelyekben az egyenes rendelkezik a „legrövidebb út” tulajdonságával.

Tanítványai, P. Funk [14] és G. Hamel [19] munkájával kezdve, majd sok más matematikus, mint W. Blaschke [4], A. V. Pogolerov [37] és Szabó Zoltán [41] munkájának köszönhetôen mára az összes ilyen „projektiv-metrikus" geometriát elố tudjuk állítani. Ezekból olyan sok van, hogy nem vizsgálhatók egyenként, de Busemann rámutatott [7], hogy a közülük kiválasztható két legfontosabb típus, mert pontosan a Minkowski- és a Hilbert-féle az, amelyben az egyenesek közti izometriák projektivitások (Minkowski-esetben konkrétan affiniftások).

A Minkowski-geometriákat alaposan ismerhetjük, hiszen a matematikusok jelentős része ezeket normált vektortérként ismeri, és igen bőséges irodalom veszi számba jellemzóiket és tulajdonságaikat [1], [40]. A Hilbert-geometriák kevésbé ismertek $^{1}$, de kutatásuk napjainkban egyre újabb és változatosabb eredményekkel zárkózik fel [36].

Ahogyan az euklideszié a Minkowski-, a hiperbolikus geometria közvetlen általánosítása a Hilbert-geometria, így utóbbiak megismerésében elsôrendú feladat az euklideszi, illetve hiperbolikus geometriában megszokott konfigurációk tulajdonságainak vizsgálata. Kérdések két vonatkozásban merülnek fel.

(1) Vajon az egyes konfigurációk mely tulajdonságai maradnak meg az általános esetben, és melyek azok, amelyek tovább már nem jellemzik a konfigurációt?

(2) Milyen következménnyel jár a geometria egészére, ha egy konfiguráció valamely tulajdonsága megmarad? Van-e olyan konfiguráció és annak valamilyen tulajdonsága, amelyek együttesen kizárják az általánosítás lehetôségét (vagyis a geometria euklideszi, illetve hiperbolikus)?

Mindkét kérdés esetén felmerül, hogy amennyiben egy tulajdonságot nem általánosságban, hanem csak egy-két esetben írunk elô, akkor is következik-e ugyanaz az eredmény?

Ebben a disszertációban olyan vizsgálatokat mutatunk be, amelyek kivétel nélkül a klasszikus euklideszi, illetve hiperbolikus geometriák Minkowski-, illetve Hilbert-geometriák közti karakterizációjához vezetnek.

Az értekezésben háromszögek Ceva- és Menelaosz-tulajdonságának Hilbert-geometriában való érvényesülését és oldalfelezô merőlegesek, illetve magasságvonalak

\footnotetext{
${ }^{1}$ Elsősorban ezért mutatjuk be a Hilbert-geometriákat kicsit részletesebben.
} 
konkurenciáját vizsgálva jutunk el karakterizációs tételekhez mind Hilbert-, mind Minkowski-geometriák esetén ([Km], [KKh], [KKc]).

Vizsgáltuk azt is, hogy egy projektív metrika klasszikus-e, ha benne egy hiperbola kvadratikus görbe, de a válaszok bemutatása túlmutat jelen értekezés témáján, ezért csak megjegyezzük, hogy a Minkowski- és a Hilbert-geometria esetében is sikerült igazolni $[\mathrm{KKq}]$, hogy egy hiperbola akkor és csak akkor kvadratikus, ha a geometria euklideszi, illetve Bolyai-féle hiperbolikus.

A disszertációban a saját eredményeket tartalmazó tanulmányokra betújelekkel, a további referenciákra számozással hivatkozunk. 


\section{Előismeretek}

A nem elfajuló háromszögeket a rövidség kedvéért trigonnak nevezzük. Ha rögzítünk egy origót, akkor az $A, B, \ldots$ pontokat azonosíthatjuk a helyvektorukkal, és a vektoriális írásmód szerint is jelöljük: $\mathbf{a}, \mathbf{b}, \ldots$

A sík origó középpontú, egységsugarú körének paraméteres felírására használni fogjuk a rövid $\mathbf{u}_{\tau}=(\cos \tau, \sin \tau)$ és $\mathbf{u}_{\tau}^{\perp}=(-\sin \tau, \cos \tau)$ jelöléseket.

A $\mathbf{c}(t), \mathbf{h}(\alpha), \ldots$ vektor-skalár függvények deriváltjaira adott pontban használjuk a $\dot{\mathbf{c}}\left(t_{0}\right)$ jelölést, illetve egyenértékúen a $\frac{d \mathbf{c}}{d t}\left(t_{0}\right)$ jelölést is.

A közös pontra illeszkedő affin egyenesek halmazát egyenesnyalábnak, a közös pontot pedig ezen egyenesnyaláb centrumának nevezzük. Ha az egyenesnyaláb centruma végtelen távoli pont, akkor párhuzamos egyenesnyalábról beszélünk. Szakaszok egy halmazáról azt mondjuk, hogy egy egyenesnyalábra illeszkednek, ha egyeneseik nyalábot alkotnak.

Affin térben a korlátos másodrendú felületeket ellipszoidnak (két dimenzióban ellipszisnek) nevezzük. Euklideszi geometriában ez éppen egy gömbfelület (két dimenzióban körvonal) affin képe [31]. A továbbiakban, gyakran a fogalmak némi zavarát kockáztatva, de a kontextusból világos módon szintén ellipszoidnak (két dimenzióban ellipszisnek) hívjuk azt a korlátos, nyílt, konvex tartományt ${ }^{2}$, melynek határa ellipszoid (két dimenzióban ellipszis).

Egy szigorúan konvex síkbeli tartomány határát oválisnak nevezzük. Egy oválist egyértelmûen meghatároz a támaszfüggvénye, amely minden irányhoz hozzárendeli a rá meróleges támaszhiperfélsíkok (két dimenzióban támaszegyenesek) origótól mért elójeles távolsága közül a nagyobbat. Az ovális támaszfüggvénye megszámlálhatóan sok iránytól eltekintve differenciálható [38, Note 2, 31. o.]. Erre tekintettel a kétszeres differenciálhatóságot a másodrendű Taylor-sorfejtés létezésével szokás definiálni, amiért a kétszeres differenciálhatóság is majdnem mindenütt fennáll, vagyis ennek feltételezése az általánosságot alig szorítja meg. A továbbiakban az oválisokról mindig feltesszük a kétszeres differenciálhatóságot.

\subsection{Osztóviszony és kettősviszony}

2.1. Definíció. $\mathrm{Az} A, B$ és $C \neq B$ kollineáris pontok $(A, B ; C)$ affin osztóviszonya az a valós szám, amelyre $(A, B ; C) \overrightarrow{B C}=\overrightarrow{A C}$.

Világos, hogy az osztóviszony folytonosan függ a benne szereplő pontoktól, kivéve a $B=C$ esetet. Az osztóviszony egyik legfontosabb megjelenése az affin geometriában a Ceva- és a Menelaosz-tétel (lásd [31, 39. o.]).

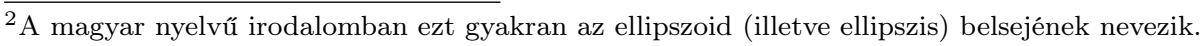


2.2. Definíció. Egy $A B C \triangle$ trigon $\left(C^{\prime}, A^{\prime}, B^{\prime}\right)$-tripletjén három olyan, a csúcsoktól különböző $C^{\prime}, A^{\prime}$ és $B^{\prime}$ pontot értünk, amelyek rendre az $A B, B C$ és $C A$ egyeneseken vannak.
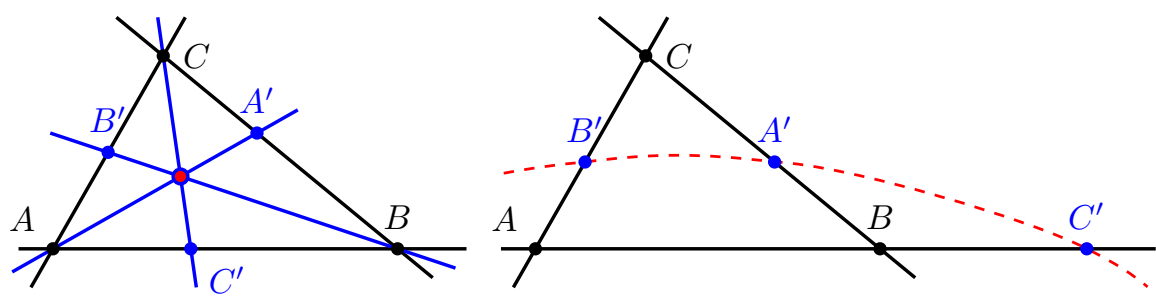

2.1. Ábra. Ceva-ponthármas és Menelaosz-ponthármas

Az $A B C$ trigon egy $\left(C^{\prime}, A^{\prime}, B^{\prime}\right)$-tripletjét

(p1) Menelaosz-tripletnek (vagy Menelaosz típusú tripletnek) nevezzük, ha a $C^{\prime}$, $A^{\prime}$ és $B^{\prime}$ pontok kollineárisak, illetve

(p2) Ceva-tripletnek (vagy Ceva típusú tripletnek) nevezzük, ha az $A A^{\prime}, B B^{\prime}$ és $C C^{\prime}$ egyenesek konkurensek.

Valós számok egy $(\alpha, \beta, \gamma)$ hármasát

(n1) Menelaosz típusúnak nevezzük, ha $\alpha \cdot \beta \cdot \gamma=-1$, illetve

(n2) Ceva típusúnak nevezzük, ha $\alpha \cdot \beta \cdot \gamma=+1$.

A vonatkozó klasszikus affin geometriai tételek a következók.

2.3. Tétel. (Ceva-tétel $\left[31,113\right.$. o.]) Az affin térben az $A B C$ trigon egy $\left(C^{\prime}, A^{\prime}, B^{\prime}\right)$ tripletje akkor és csak akkor Ceva típusú, ha az $\left(\left(A, B ; C^{\prime}\right),\left(B, C ; A^{\prime}\right),\left(C, A ; B^{\prime}\right)\right)$ számhármas Ceva típusú.

2.4. Tétel. (Menelaosz-tétel $[31,114$. o.]) Affin térben az ABC $\triangle$ trigon egy $\left(C^{\prime}, A^{\prime}, B^{\prime}\right)$-tripletje akkor és csak akkor Menelaosz típusú, ha Menelaosz típusú az $\left(\left(A, B ; A^{\prime}\right),\left(B, C ; A^{\prime}\right),\left(C, A ; B^{\prime}\right)\right)$ számhármas.

Projektív terekben a kettôsviszonyt a homogén koordináták használatával definiálják, de ha a négy pont közös affin térbe esik, akkor az osztóviszonyokkal is megadható.

2.5. Definíció. A kollineáris $A, B$ és $C \neq B, D \neq B$ pontok affin kettôsviszonya az $(A, B ; C, D)=(A, B ; C) /(A, B ; D)$ valós szám.

Mivel az osztóviszony kivételektól eltekintve folytonosan függ a benne szerepló pontoktól, ez a kettôsviszonyra is érvényes.

A kettôsviszony alkalmazása lehetôvé teszi a klasszikus Ceva- és Menelaosztétel egyesített projektív tárgyalását (lásd [KKp, 2.2. tétel]). Ehhez a 2.1. Ábra bal 
oldalán szereplő eredeti Ceva-konfigurációt kiegészítjük egyenesekkel és pontokkal a bôvítéssel származtatott projektív síkon (lásd a 2.2. Ábrát).

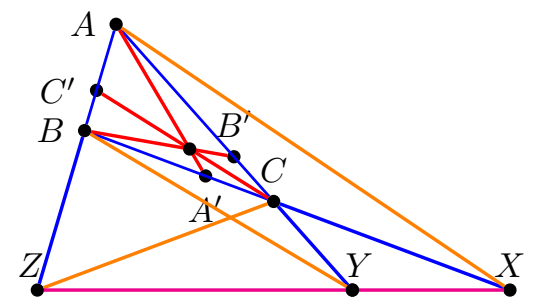

2.2. Ábra. Projektív Ceva-konfiguráció

2.6. Tétel. ([KKp, 2.2 Tétel]) Legyen $f_{A}, f_{B}$ és $f_{C}$ az $A B C \triangle$ trigon csúcsain átmenö egy-egy egyenes, és legyen $X, Y$ és $Z$ rendre az $A B C \triangle$ oldalegyenesein egy-egy pont. $A z A^{\prime}, B^{\prime}$ és $C^{\prime}$ pont legyen rendre az $f_{A}, f_{B}$ és $f_{C}$ egyenes metszete a szemközti oldal egyenesével.

(1) $H a f_{A}, f_{B}$ és $f_{C}$ konkurensek, és az X,Y,Z pontok kollineárisak, akkor

$$
\left(A, B ; C^{\prime}, Z\right)\left(B, C ; A^{\prime}, X\right)\left(C, A ; B^{\prime}, Y\right)=-1 .
$$

(2) Ha (2.1) teljesül, akkor az X,Y,Z pontok pontosan akkor kollineárisak, ha az $f_{A}, f_{B}$ és $f_{C}$ egyenesek konkurensek.

\subsection{Ellipszoidmetszetek és a John-Löwner-ellipszoid}

Egy ellipszoid felismerhetô a síkmetszetei által.

2.7. Lemma. ([16, Lemma 12.1]) $A z \mathbb{R}^{n}(n \geq 2)$ egy korlátos, nyílt konvex $\mathcal{H}$ halmaza akkor és csak akkor egy $C$ centrumú ellipszoid, ha a $C$-n átmenó bármely kétdimenziós síkkal való metszete egy ellipszis.

Szokásos kompaktsági megfontolásokkal belátható, hogy az $\mathbb{R}^{n}$ térben minden $\mathcal{K}$ konvex test (konvex halmaz belsô pontokkal) esetén van egy maximális térfogatú beírt ún. John-ellipszoid [24], és egy minimális térfogatú körülírt ún. Löwner-ellipszoid (lásd pl. [17]).

2.8. Lemma. ([21, Theorem 2.1]) Legyen $\mathcal{K} \subset \mathbb{R}^{n}$ egy konvex test, és legyen $\mathcal{E} \supseteq \mathcal{K}$ egy ốt tartalmazó ellipszoid. Ekkor a következó állítások ekvivalensek:

(1) $\mathcal{E}$ minimális térfogatú.

(2) Vannak $\mathbf{e}_{1}, \ldots, \mathbf{e}_{m} \in \partial \mathcal{K} \cap \partial \mathcal{E}$ érintési pontok, és léteznek $\lambda_{1}, \ldots, \lambda_{m}(m \geq n)$ pozitív számok úgy, hogy $\sum_{i=1}^{m} \lambda_{i} \mathbf{e}_{i}=0$, és $I_{n}=\sum_{i=1}^{m} \lambda_{i}\left(\mathbf{e}_{i} \mathbf{e}_{i}^{T}\right)$, ahol $I_{n}$ $a z(n \times n)$-es négyzetes mátrix. 
A számunkra érdekes kétdimenziós esetben a következók fogalmazhatók meg. 2.9. Lemma. ([KKc] Lemma 2.2) A sikban minden olyan nem üres, nyílt, konvex $\mathcal{H}$ halmazhoz, amely nem ellipszis, létezik egy olyan, $\mathcal{H}$-t tartalmazó $\mathcal{E}$ ellipszis, amelyre az $\partial \mathcal{E} \backslash \mathcal{H}$ halmaznak legalább 6 különbözö pontja van, és $\mathcal{E} \backslash \mathcal{H}$ nem üres.

A John-Löwner-ellipszoidokra vonatkozó alábbi lemma egyes állításaira szükségünk lesz késóbbi bizonyításainkban.

2.10. Lemma. ([KKh, Lemma 3.3]) Legyen $\mathcal{H}$ egy konvex tartomány a sikban. Ekkor

(1) létezik a $\mathcal{H}$-nak egy $\mathcal{E}$ köréirt ellipszise legalább három különbözó $E_{1}, E_{2}, E_{3}$ érintési ponttal a $\partial \mathcal{H} \cap \partial \mathcal{E}$ halmazban úgy, hogy a zárt $E_{1} E_{2} E_{3} \triangle$ tartalmazza a $\mathcal{E}$ ellipszis $C$ centrumát, és

(2) ha $\mathcal{H} \not \equiv \mathcal{E}$, akkor ezek az érintési pontok választhatók úgy, hogy közülük az egyiknek minden környezetében teljesül a $\partial \mathcal{H} \backslash \partial \mathcal{E} \neq \emptyset$ feltétel.

Legyenek $t_{1}, t_{2}$ és $t_{3}$ a két alakzat közös érintöi az $E_{1}, E_{2}$, illetve $E_{3}$ pontban. Ekkor

(3) ha $E_{1} E_{2} E_{3} \triangle$ a belsejében tartalmazza a $C$ pontot, akkor $t_{1}, t_{2}, t_{3}$ egy trigont alkot az $M_{1}=t_{2} \cap t_{3}, M_{2}=t_{3} \cap t_{1}$ és $M_{3}=t_{1} \cap t_{2}$ csúcsokkal úgy, hogy $e$ trigon az $E_{1}, E_{2}, E_{3}$ érintési pontok kivételével a belsejében tartalmazza az $\mathcal{E}$ ellipszist;

(4) $h a$ az $E_{1} E_{2} E_{3} \triangle$ háromszög valamelyik oldala tartalmazza $C$ - $t$, mondjuk, $C \in$ $\overline{E_{2} E_{3}}$, akkor a három érintố a síknak egy párhuzamosok közötti olyan félsávját határozza meg, amelynek (esetleg ideális) csúcsai $M_{2}=t_{1} \cap t_{3}, M_{3}=t_{2} \cap t_{1}$, és ez a belsejében tartalmazza a $\mathcal{E}$ ellipszist, kivéve az $E_{1}, E_{2}, E_{3}$ érintési pontokat.

Ha $B_{1}, B_{2}, B_{3}$ rendre az $\overline{E_{2} E_{3}}, \overline{E_{3} E_{1}}$ és $\overline{E_{1} E_{2}}$ szakaszok felezöpontja, akkor

(5) az $M_{i} B_{i}(i=1,2,3)$ egyenesek a $C$ pontban találkoznak.

Bizonyítás. Tekintsük a minimális területú $\mathcal{E}$ ellipszist, mely tartalmazza $\mathcal{H}$-t, és legyen ennek középpontjában az $O$ origó. (1) A 2.8. Lemma (2) állítása szerint van egy $(5 \geq) m \geq 3$ egész szám úgy, hogy léteznek $E_{1}, \ldots, E_{m}$ érintési pontok a $\partial \mathcal{H} \cap \partial \mathcal{E}$ halmazban azzal a feltétellel, hogy valamely pozitív lineáris kombinációjuk eltûnik.

Ez azt jelenti, hogy az origó ezeknek az érintési pontoknak a konvex burkában van. Emiatt valamelyik hármójuk által alkotott (zárt) trigon — mondjuk, az $E_{1} E_{2} E_{3} \triangle$ - szintén tartalmazza az origót.

(2) Transzformáljuk az (1)-ben adott konfigurációt egy $\Phi$ lineáris affinitással oly módon, hogy a $\mathcal{D}=\Phi(\mathcal{E})$ képhalmaz az origó centrumú egységsugarú körlemez legyen. Legyen $E_{i}^{\prime}=\Phi\left(E_{i}\right)(i=1,2,3)$, és $\mathcal{H}^{\prime}=\Phi(\mathcal{H})$.

$\mathrm{Az}$ (1) szerint az $O$ középpont az $E_{1}^{\prime} E_{2}^{\prime} E_{3}^{\prime} \triangle$ trigonban van. 
Legyenek $\varepsilon_{i} \in(-\pi, \pi]$ olyan számok, hogy $E_{i}^{\prime}=\mathbf{u}_{\varepsilon_{i}}$, és a $\mathcal{H}^{\prime}$ támaszfüggvényét jelölje $h_{\mathcal{H}^{\prime}}$. Vegyük ezután az $\alpha_{i}:=\lim \sup \left\{\alpha: h_{\mathcal{H}^{\prime}}\left(\left[\varepsilon_{i}, \alpha\right]\right)=\{1\}\right\} \quad(i=1,2,3)$ számokat. Ha $\alpha_{i}$ végtelen, akkor $\mathcal{H} \equiv \mathcal{E}$, de ennek az ellenkezôjét tettük fel. Tegyük fel, hogy $\alpha_{k}=\min _{i \in\{1,2,3\}} \alpha_{i}, k \in\{1,2,3\}$.

Az $F_{i}=\Phi^{-1}\left(\mathbf{u}_{\varepsilon_{i}+\alpha_{k}}\right)(i=1,2,3)$ pontok a $\partial \mathcal{H}$ és $\partial \mathcal{E}$ halmazok érintkezési pontjai, továbbá az $F_{1} F_{2} F_{3} \triangle$ trigon tartalmazza az $O$ középpontot, és az $F_{1}$ minden $\mathcal{N}$ környezetében igaz, hogy $(\partial \mathcal{H} \backslash \partial \mathcal{E}) \cap \mathcal{N} \neq \emptyset$.

A (3) és (4) állítás egyszerú következménye az $\mathcal{E}$ ellipszis szigorú konvexitásának. Az (5) állítást azonnal megkapjuk, ha az ellipszist egy lineáris affinitással egy körré transzformáljuk.

E lemmákat kiegészíti a következô, melynek igazolásához elegendô figyelembe venni, hogy egy ellipszoid szimmetriacentruma egyértelmúen meghatározott, és egy centrálisan szimmetrikus test középpontjára való tükrözés az egyértelmúen meghatározott John-Löwner-ellipszoidját is invariánsan hagyja.

2.11. Lemma. Egy centrálisan szimmetrikus, korlátos, konvex test és a köré írt John-Löwner-ellipszoid középpontja megegyezik.

\subsection{A Minkowski-geometriákról}

Legyen $\mathcal{I}$, az indikátrix, egy nyílt, szigorúan konvex, az origóra középpontosan szimmetrikus, korlátos tartomány az $\mathbb{R}^{n}$ térben. Jól ismert ([30], [31]), hogy a $d_{\mathcal{I}}: \mathbb{R}^{n} \times \mathbb{R}^{n} \rightarrow \mathbb{R}$ függvény, melyet

$$
d_{\mathcal{I}}(\mathbf{x}, \mathbf{y})=\inf \{\lambda>0:(\mathbf{y}-\mathbf{x}) / \lambda \in \mathcal{I}\}
$$

definiál, egy metrika az $\mathbb{R}^{n}$ téren. Ezt Minkowski-metrikának nevezzük. Az affin teret ezzel a metrikával Minkowski-geometriának nevezzük ${ }^{3}$, amit $\left(\mathbb{R}^{n}, d_{\mathcal{I}}\right)$ jelöl.

A kollineáris $A, B$ és $C \neq B$ pontok (ilyen sorrendben vett) $d_{\mathcal{I}}$-metrikus osztóviszonyán az

$$
(A, B ; C)_{d_{\mathcal{I}}}=\left\{\begin{aligned}
-\frac{d_{\mathcal{I}}(A, C)}{d_{\mathcal{I}}(C, B)}, & \text { ha } C \in \overline{A B}, \\
\frac{d_{\mathcal{I}}(A, C)}{d_{\mathcal{I}}(C, B)}, & \text { egyébként }
\end{aligned}\right.
$$

valós számot értjük.Világos, hogy ez megegyezik az affin osztóviszonnyal, így Ceva és Menelaosz tételei a metrikus osztóviszonnyal is teljesülnek.

\footnotetext{
${ }_{3}^{3}$,Azoknak a normáknak a tanulmányozása, amelyek különböznek az euklideszitől, elsődlegesen Minkowskitól ered."[12] Innentôl terjedt el az irodalomban a Minkowski-geometria elnevezés. Minkowski e tárgykörhöz sorolhatóan 1897-1911 között hat jelentôs tanulmányt publikált. Maga a téma két szálon indult. Brunn konvexitáselméleti és az absztrakt lineáris terek olaszországi iskolájának munkásságát Minkowski fúzte össze.
} 
2.12. Definíció. ([40, Definition 3.2.2]) A $C$ szimmetriacentrumú $\mathcal{I}$ indikátrixszal meghatározott Minkowski-geometriában az $\ell$ egyenes bal-meróleges az $m$ egyenesre, ha az $m$-lel párhuzamos, $C$-n átmenố $m^{\prime}$ egyenesnek az $\mathcal{I}$-vel vett metszéspontján átmenô, $\ell$-lel párhuzamos $\ell^{\prime}$ egyenes érinti $\mathcal{I}$-t. Jelölése: $\ell \perp_{b} m$.

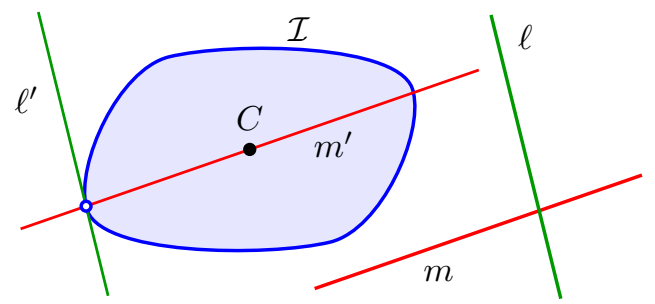

2.3. Ábra. Merôlegesség Minkowski-geometriában

Ez a merôlegesség nem szimmetrikus reláció, ezért láttuk el a „bal” előtaggal. Ennek inverze a $\perp_{j}$ jobb-merólegesség, vagyis $\ell \perp_{b} m \Leftrightarrow m \perp_{j} \ell$.

A definíció következménye, hogy az ugyanazon egyenesre bal-, illetve jobbmerőleges egyenesek egymással párhuzamosak (lásd a 2.3. Ábrát). Az is igaz továbbá, hogy a szigorú konvexség következtében két egyenes pontosan akkor párhuzamos, ha a rájuk bal-, illetve jobb-merôleges egyenesek egymással párhuzamosak. Következésképpen metszô egyenesekre bal(jobb)-meróleges egyenesek is metszók.

A bal- és a jobb-merőlegesség 2-nél magasabb dimenzióban akkor és csak akkor esik egybe, ha $\mathcal{I}$ egy ellipszoid. A síkban ez az egybeesés pontosan akkor teljesül, ha $\partial \mathcal{I}$ egy Radon-görbe (lásd [10]).

Az euklideszi geometriában minden háromszög oldalfelezô merôlegesei a háromszög köré írt kör középpontjára illeszkednek, a magasságvonalai pedig a háromszög magasságpontjára. Minkowski-geometriában az általában meglévő kétféle merőlegesség a háromszögek magasságpontjára is kétféle állítást ad: a jobb-merôleges magasságvonalak (jobb-magasságok), illetve a bal-merőleges magasságvonalak (balmagasságok) egyeneseinek egy pontra illeszkedésére is vannak tételek (5.2. Tétel és 5.4. Tétel). Ha a jobb-merôleges magasságvonalak egy ponton mennek át, e pontot jobb-ortocentrumnak nevezzük, ha a bal-meróleges magasságvonalakra igaz ez, akkor bal-ortocentrumnak nevezzük.

Hasonlóképpen külön tételeket igazolhatunk háromszögekre a bal-merőlegességnek eleget tévố oldalfelezô merőleges egyenesek metszéspontjának (bal-biszektorális középpont), illetve a jobb-merőlegességnek eleget tévő oldalfelező merôleges egyenesek metszéspontjának (jobb-biszektorális középpont) létezéséről (5.3. Tétel és 5.1. Tétel). 


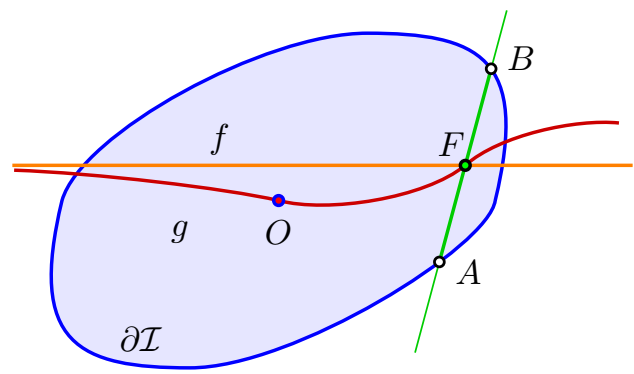

2.4. Ábra. Kétpontekvidisztáns $g$ görbe és $f$ szakaszfelezô merôleges

Síkban két ponttól megegyező távolságra lévő pontok halmazát kétpontekvidisztáns görbének nevezzük. Egy szakasz felezô meróleges egyenese általában nem egyezik meg a végpontjai által meghatározott kétpontekvidisztáns görbével. Erre mutat példát a 2.4. Ábra. Az indikátrix $\partial \mathcal{I}$ határán lévô $A$ és $B$ pontok szakaszának felezôpontja $F$, felezô merôleges egyenese $f$, míg kétpontekvidisztáns görbéje $g$. Ez nyilván átmegy az $F$ felezőponton és az indikátrix $O$ középpontján, középpontosan szimmetrikus $F$-re, továbbá aszimptotája az $f$ egyenes.

Az euklideszi geometria Minkowski-geometriák közti karakterizációjára az [1] könyvben mintegy 300 kritériumot találhatunk. Ezek egy része a különféle merőlegességfogalmakhoz kapcsolódik, mint például az [11], hogy egy Minkowski-sík akkor és csak akkor euklideszi, ha az egységkör bármely $\mathbf{x}$ és $\mathbf{y}$ vektorára $(\mathbf{x}+\mathbf{y}) \perp_{b}(\mathbf{x}-\mathbf{y})$.

\subsection{A hiperbolikus geometriáról modellekkel}

Mivel eredményeink igazolását vissza tudjuk vezetni síkbeli megfontolásokra, most elegendő a kétdimenziós modellekkel foglalkoznunk.

A $\mathbb{H}^{2}$ hiperbolikus sík alábbi modelljei az ( $\mathbb{R}^{2}$-vel megfelelően azonosított) euklideszi sík egy-egy tartományáról való paraméterezésnek tekinthetók. Ebben az értelemben a szögtartó paraméterezés adja a Poincaré-féle körmodellt, a geodetikusokat tartó paraméterezés pedig a Cayley-Klein-modellt ${ }^{4}$.

Ez utóbbit $\mathbb{K}_{\varrho}^{c}$ jelöli, és úgy kapjuk [30], hogy pontjai a $\mathcal{B}^{2}$ belsô pontjai, egyenesei a $\mathcal{B}^{1}$ körlap nyílt húrjai, az $X, Y \in \mathbb{K}_{\varrho}^{c}$ pontok közötti távolságot pedig $d(X, Y)=\varrho|\ln \sqrt{(A, B ; X, Y)}|$ definiálja, ahol $A$ és $B$ a $\mathcal{B}^{1}$ körlap $X$ és $Y$ pontra illeszkedő húrjának az $\mathcal{S}^{1}$ körvonalra esô pontjai.

$\mathrm{A} \mathbb{K}_{\varrho}^{p}$ Poincaré-féle körmodellben egyeneseknek nevezzük az átméróket és az $\mathcal{S}^{1}$ kört merólegesen metszố körök $\mathcal{B}^{1}$-be esố íveit, az $X, Y \in \mathbb{K}_{\varrho}^{p}$ pontok közötti távolságot pedig $d(X, Y)=\varrho|\ln (A, B ; X, Y)|$ adja, ahol $A$ és $B$ az $X$ és $Y$ pontra illeszkedő, az $\mathcal{S}^{1}$ kört merôlegesen metsző kör két metszéspontja az $\mathcal{S}^{1}$ körrel.

\footnotetext{
${ }^{4}$ Vagy annak affin transzformáltjai, melyeket affin CK-modellnek nevezünk.
} 
A $\Phi: \mathcal{B}^{1} \rightarrow \mathcal{B}^{1}$ transzformáció, melyre $\Phi(\varphi, r)=\left(\varphi, \frac{2 r}{1+r^{2}}\right)$, bijektíven képezi a $\mathcal{B}^{1}$ egységkörlapot önmagára, megtartja az origón áthaladó egyeneseket, az egységkört merôlegesen metszố minden körívet a körív metszéspontjait összekötô húrba visz, és a kettôsviszonyt a négyzetébe viszi, ezért a két modell között a $\Phi: \mathbb{K}_{\varrho}^{p} \rightarrow \mathbb{K}_{\varrho}^{c}$ leképezéssel leírt kapcsolat izometria [30, 118. oldal].

Egy hiperbolikus $t$ egyenesre tükrözés a Poincaré-modellben annak az inverziónak a $\mathcal{B}^{1}$-re vett megszorítása, melynek alapköre az $\mathcal{S}^{1}$ kört a $t$ körív végpontjaiban merőlegesen metszô $\mathcal{T}$ kör. Eszerint adott különbözó $P$ és $P^{\prime}$ pontok esetén a $P$-t a $P^{\prime}$-be vivő tükrözés tengelye egy olyan körnek a $\mathcal{B}^{1}$-be esố íve, amely átmegy a két ponton, és merólegesen metszi $\mathcal{S}^{1}$-et. Pontosan egy ilyen kör van, ezért pontosan egy olyan tengelyes tükrözés van, amely a két pontot felcseréli.

Az egységkör középpontján átmenő egyenesre hiperbolikus értelemben merőleges egyenesek a Cayley-Klein-modellben euklideszi értelemben is merólegesek, ugyanis $\Phi$ egy $O$-n átmenő $\ell$ egyenesre meróleges Poincaré-modellbeli egyenest (amely ott egy $\ell$-re és $\mathcal{S}^{1}$-re is merốleges kör íve) az invariáns $\ell$-re euklideszi értelemben meróleges egyenesbe viszi.

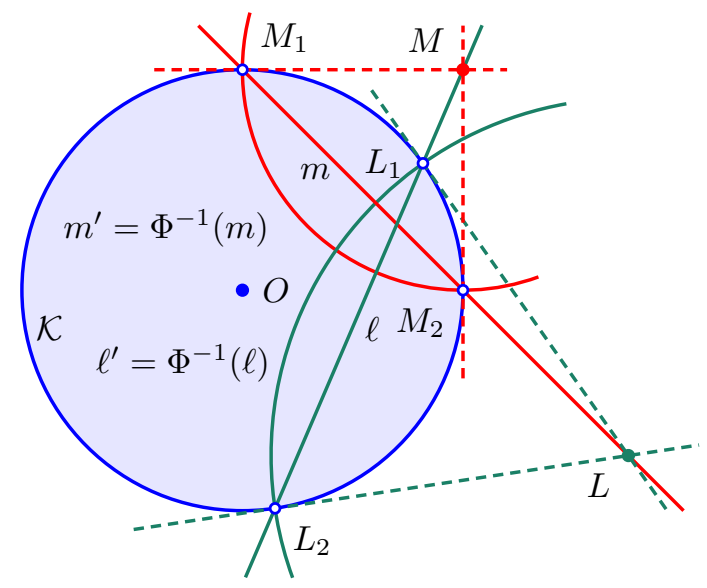

2.5. Ábra. Merőlegesség a Cayley-Klein- és a Poincaré-modellben

Mi jellemzi a Cayley-Klein-modellben a merôleges $\ell$ és $m$ egyeneseket? Az elöző́k szerint az $\ell$ végpontjain átmenő, $\mathcal{S}^{1}$-re merőleges $\Phi^{-1}(\ell)$ körív és az $m$ végpontjain átmenô, $\mathcal{S}^{1}$-re merôleges $\Phi^{-1}(m)$ körív a Poincaré-modell két merôleges egyenese. Ezért a $\Phi^{-1}(\ell)$ körének középpontjából a másik két körhöz húzható érintốszakaszok hossza (a középpont és a metszéspontok távolsága) megegyezik, tehát e középpont rajta van a másik két kör hatványvonalán. Ez az egyenes pedig megegyezik a másik két kör metszéspontjain áthaladó $m$ egyenessel. Tehát a meróleges 
egyenesek végpontjaiban az $\mathcal{S}^{1}$-hez húzott érintök a másik egyenes euklideszi síkbeli kiterjesztésén metszik egymást.

A két modell közti kapcsolatból következik, hogy bármelyik modellt tekintjük is, tükrözésekkel a modell bármely pontja „,bevihetô” a kör középpontjába, vagyis az euklideszi értelemben kiemelt középpont a hiperbolikus geometria szempontjából nem különbözik a többitôl. Ez lehetôvé teszi, hogy konfigurációkkal kapcsolatos tételek igazolása, illetve bizonyos számítások könnyebb elvégezhetôsége érdekében a modellt eleve úgy válasszuk, hogy valamely célszerúen választott pont a középpontban legyen. Ezt fogjuk követni pl. a hiperbolikus Ceva-tétel (2.15. Tétel) és a hiperbolikus Menelaosz-tétel (2.14. Tétel), továbbá a háromszögek magasságvonalainak (4.4. Tétel), illetve oldalfelezó meróleges egyeneseinek egy nyalábhoz tartozásának (4.3. Tétel) igazolásakor.

2.13. Definíció. A kollineáris $A, B \neq A, C \neq B$ (ilyen sorrendben vett) pontok hiperbolikus (metrikus) osztóviszonya ${ }^{5}$

$$
\langle A, B ; C\rangle=\left\{\begin{aligned}
-\frac{\operatorname{sh} d(A, C)}{\operatorname{sh} d(C, B)}, & \text { ha } C \in \overline{A B}, \\
\frac{\operatorname{sh} d(A, C)}{\operatorname{sh} d(C, B)}, & \text { egyébként. }
\end{aligned}\right.
$$

A $C$ pont (3.1) szerint bijektív kapcsolatban van $\langle A, B ; C\rangle$ értékével.

2.14. Tétel. (Hiperbolikus Menelaosz-tétel [33, 467-468. о.]) A hiperbolikus térben az $A B C \triangle$ trigon egy $\left(C^{\prime}, A^{\prime}, B^{\prime}\right)$-tripletje akkor és csak akkor Menelaosz típusú, ha az $\left(\left\langle A, B ; C^{\prime}\right\rangle,\left\langle B, C ; A^{\prime}\right\rangle,\left\langle C, A ; B^{\prime}\right\rangle\right)$ számhármas Menelaosz típusú.

Bizonyítás. Használjuk a Cayley-Klein-modellt! Tegyük fel, hogy a $\left(C^{\prime}, A^{\prime}, B^{\prime}\right)$ triplet Menelaosz típusú, $\ell$ egyenesük a $\mathcal{K}$ egy átmérôje. Ekkor a trigon $A, B, C$ csúcsai nincsenek az átmérôn, és $T_{A}, T_{B}, T_{C}$ meróleges vetületeikre $\overline{A T_{A}}, \overline{B T_{B}}$, $\overline{C T_{C}}$ az $\ell$-re meróleges szakaszok euklideszi értelemben is (lásd a 2.6. Ábrát).

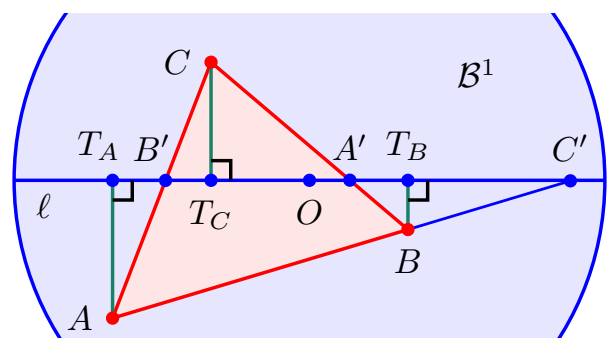

2.6. Ábra. Hiperbolikus Menelaosz-tétel

\footnotetext{
${ }^{5} \mathrm{~A}$ hiperbolikus megnevezés nem a térre, hanem a formula hiperbolikus függvényeire utal. A használt metrikát, ha nem lenne egyértelmú, akkor az alsó indexben egyértelmû utalással jelezzük.
} 
A hiperbolikus sík szinusz-tétele [30, 123. o.] szerint

$$
\begin{aligned}
\left|\left\langle A, B ; C^{\prime}\right\rangle\right|\left|\left\langle B, C ; A^{\prime}\right\rangle\right|\left|\left\langle C, A ; B^{\prime}\right\rangle\right| & =\frac{\operatorname{sh} d\left(A, C^{\prime}\right)}{\operatorname{sh} d\left(C^{\prime}, B\right)} \frac{\operatorname{sh}\left(B, A^{\prime}\right)}{\operatorname{sh} d\left(A^{\prime}, C\right)} \frac{\operatorname{sh} d\left(C, B^{\prime}\right)}{\operatorname{sh} d\left(B^{\prime}, A\right)} \\
& =\frac{\operatorname{sh} d\left(T_{A}, A\right)}{\operatorname{sh} d\left(T_{B}, B\right)} \frac{\operatorname{sh} d\left(T_{B}, B\right)}{\operatorname{sh} d\left(T_{C}, C\right)} \frac{\operatorname{sh} d\left(T_{C}, C\right)}{\operatorname{sh} d\left(T_{A}, A\right)}=1
\end{aligned}
$$

teljesül. Mivel $\ell$ a trigonnak pontosan 0 vagy 2 oldalát metszi a Pasch-axióma miatt, az osztóviszonyok szorzata -1 .

Megfordítva tegyük föl, hogy egy $\left(C^{\prime}, A^{\prime}, B^{\prime}\right)$ tripletre az osztóviszonyok $(\gamma, \alpha, \beta):=\left(\left\langle A, B ; C^{\prime}\right\rangle,\left\langle B, C ; A^{\prime}\right\rangle,\left\langle C, A ; B^{\prime}\right\rangle\right)$ számhármasa Menelaosz típusú. Ekkor a tripletból két pont (mondjuk, $B^{\prime}$ és $A^{\prime}$ ) egyenesének és a harmadik oldalnak a $C^{*}$ metszéspontja az elôzó két ponttal a $\left(C^{*}, A^{\prime}, B^{\prime}\right)$ Menelaosz-tripletet alkotja. Így bizonyításunk elsố része szerint $\left(\gamma^{*}, \alpha, \beta\right):=\left(\left\langle A, B ; C^{*}\right\rangle,\left\langle B, C ; A^{\prime}\right\rangle,\left\langle C, A ; B^{\prime}\right\rangle\right)$ is Menelaosz típusú. A $\gamma \alpha \beta=\gamma^{*} \alpha \beta=-1$ következtében $\gamma^{*}=\gamma$, és így a tétel előtti észrevételre tekintettel $C^{\prime}=C^{*}$.

2.15. Tétel. (Hiperbolikus Ceva-tétel [33, 467-468. о.]) A hiperbolikus térben az $A B C \triangle$ trigon egy $\left(C^{\prime}, A^{\prime}, B^{\prime}\right)$-tripletje akkor és csak akkor Ceva típusú, ha az $\left(\left\langle A, B ; C^{\prime}\right\rangle,\left\langle B, C ; A^{\prime}\right\rangle,\left\langle C, A ; B^{\prime}\right\rangle\right)$ számhármas Ceva típusú.

Bizonyítás. Annak megmutatását, hogy az $M$ pontra illeszkedô egyeneseket adó Ceva típusú tripletre a megfeleló osztóviszonyok számhármasa Ceva típusú, visszavezetjük a Menelaosz-tétel szükséges részére (lásd a 2.7. Ábrát).

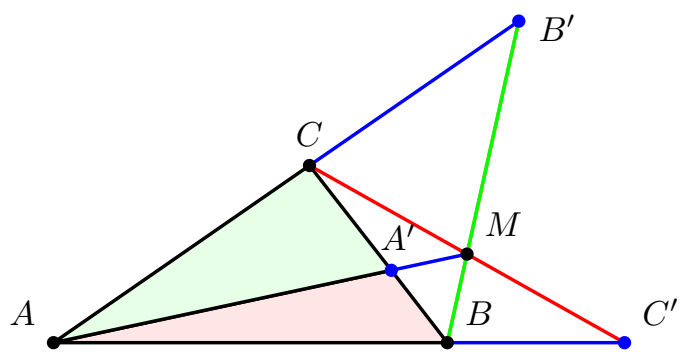

2.7. Ábra. Hiperbolikus Ceva-tétel

Az $A B A^{\prime}$ trigonra és $C M$ egyenesre, valamint az $A A^{\prime} C$ trigonra és a $B M$ egyenesre felírt Menelaosz-tétel szerint

$$
\left|\left\langle A, B ; C^{\prime}\right\rangle\right|\left|\left\langle B, A^{\prime} ; C\right\rangle\right|\left|\left\langle A^{\prime}, A ; M\right\rangle\right|=1=\left|\left\langle C, A ; B^{\prime}\right\rangle\right|\left|\left\langle A, A^{\prime} ; M\right\rangle\right|\left|\left\langle A^{\prime}, C ; B\right\rangle\right| .
$$

Ezek szorzata az arányok beírását követô egyszerúsítés után éppen az állítás, mivel az $M$ ponton átmenó egyenesek közül pontosan 1 vagy 3 metszi a trigon oldalait. 
A megfordításnál hasonlóan járhatunk el, mint a Menelaosz-tétel esetén: a triplet két pontja által meghatározott egyenesek közös $M$ pontján át húzott harmadik egyenesnek a harmadik oldallal vett metszéspontja egy Ceva-tripletet eredményez, amelynek megfelelô osztóviszonyok számhármasa Ceva típusú. A régi és új Ceva típusú számhármas két tényezôje megegyezik, ezért a harmadik is, és ez az osztópontok megegyezését eredményezi.

Az euklideszi geometria bármely háromszöge oldalainak felezô merólegesei és magasságvonalai is konkurensek. Hiperbolikus geometriában általában sem az oldalfelezó meróleges egyenesek, sem a magasságvonalak egyenesei nem illeszkednek közös pontra, sôt az oldalt a felezôpontjában metszô merôleges egyenes általában nem az oldal végpontjainak ekvidisztáns görbéje.

Hiberbolikus síkon egyenesek egy halmazát nyalábnak nevezzük, ha affin kiterjesztéseik nyalábot alkotnak.
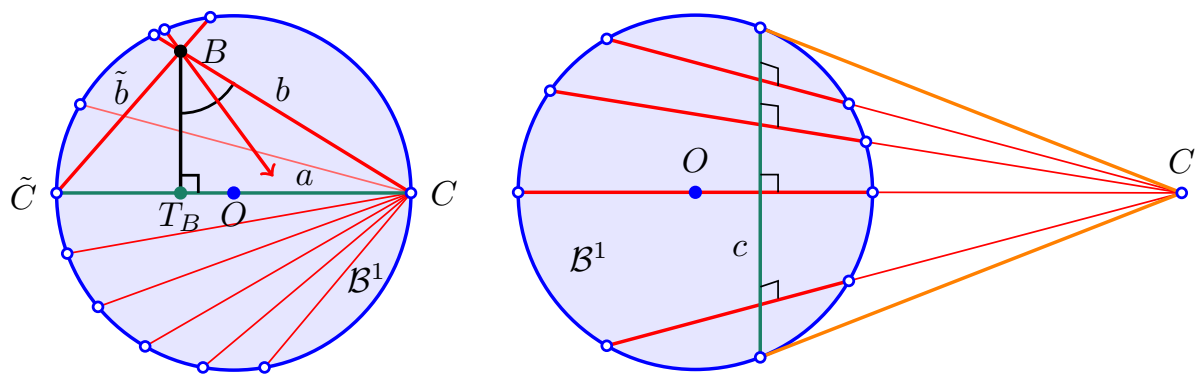

2.8. Ábra. Paranyaláb, párhuzamosság és hipernyaláb

Egy nyalábot aszerint, hogy centruma a $\mathcal{B}^{1}$ belsejébe, határára vagy külsô pontjába esik, rendre (S) sugárnyalábnak, $(\mathrm{P})$ paranyalábnak, illetve $(\mathrm{H})$ hipernyalábnak nevezzük. Egy $(\mathrm{H})$ hipernyaláb hiperbolikus egyeneseihez mindig van olyan hiperbolikus egyenes, mely mindre meróleges, hiszen a nyaláb centrumából a $\mathcal{K}$-hoz húzott érintők érintési pontjait összekötő egyenes éppen ilyen.

Ha egy háromszög oldalfelezó merólegesei egy nyalábhoz tartoznak, akkor azt mondjuk, hogy van biszektorális centruma. Ha magasságvonalai tartoznak egy egyenesnyalábhoz, akkor ortocentrumról beszélünk.

2.16. Tétel. (Hiperbolikus biszektorális centrum tétele [33, p. 350]) Hiperbolikus térben bármely trigon oldalfelezô merólegesei egy nyalábhoz tartoznak.

Bizonyítás. Legyen $A B C \triangle$ egy trigon, ennek oldalfelező pontjai a csúcsokkal szemközti oldalakon rendre $F_{A}, F_{B}$ és $F_{C}$. Elegendő azt megmutatni, hogy ha két oldalfelezô meróleges egyenes egy nyalábhoz tartozik, akkor a harmadik is ehhez a nyalábhoz tartozik. 

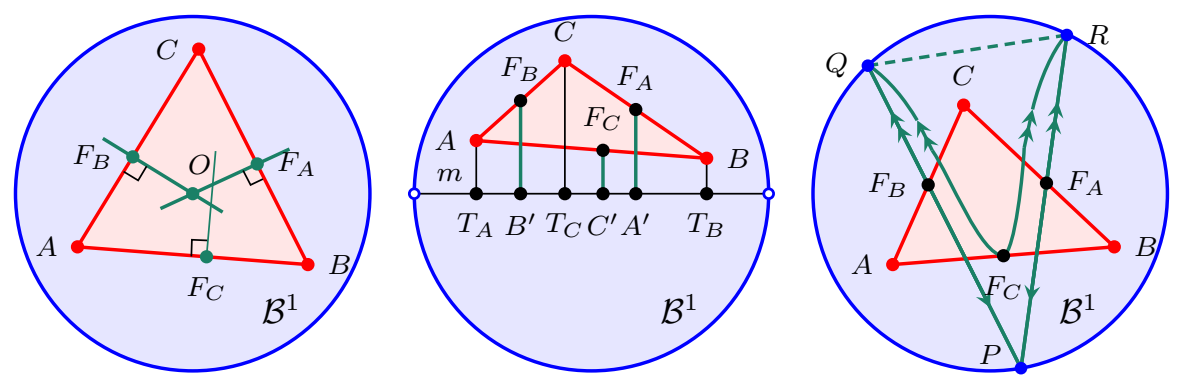

2.9. Ábra. Oldalfelezô merőlegesek sugár-, hiper- és paranyaláb esetén

(S) Tegyük fel, hogy két oldal felezô merôlegese egy sugárnyalábhoz tartozik, legyenek ezek az $\overline{A C}$ és a $\overline{B C}$ oldalak $\overline{F_{B} O}$ és $\overline{F_{A} O}$ felezô merôleges egyenesei. Helyezzük el úgy az $A B C$ trigont a $\mathcal{K}$ körben, hogy e metszéspont az $O$-ba essen. Ekkor az $O$-n átmenő $\overline{F_{A} O}$ és $\overline{F_{B} O}$ a modellben euklideszi értelemben is meróleges. Továbbá a $d(O, A)=d(O, C)$. Az $O$ választása miatt így az $\overline{O A}$ és $\overline{O C}$ szakaszok euklideszi távolsága is megegyezik, hasonlóképpen az $\overline{O B}$ szakaszéval is. Azt kaptuk, hogy $\overline{F_{A} O}$ és $\overline{F_{B} O}$ a megfelelô oldalaknak euklideszi értelemben is felezô merôleges egyenesei. Így $\overline{A O}$ és $\overline{B O}$ szakaszok hiperbolikus és euklideszi hosszúsága is megegyezik, vagyis $\overline{F_{C} O}$ meróleges az $\overline{A B}$ oldalra (lásd a 2.9. Ábrát). Eszerint a harmadik oldal felezô meróleges egyenese is a sugársorhoz tartozik.

$(\mathrm{H})$ Tegyük fel, hogy az $\overline{A C}$ oldal $F_{B}$ és a $\overline{B C}$ oldal $F_{A}$ pontján átmenő felezô meróleges egyenese egy hipernyalábot határoznak meg. Ekkor van pontosan egy közös meróleges $m$ egyenesük. Vegyünk fel olyan Cayley-Klein-modellt, amelynek $O$ középpontja ezen az egyenesen helyezkedik el úgy, hogy az abban állított $l$ meróleges egyenes átmegy az $\overline{A B}$ oldalt felező $F_{C}$ ponton! Legyen $T_{A}, T_{B}$ és $T_{C}$ az $A, B$ és $C$ talppontja $m$-en. Az $F_{B} B^{\prime}$ és az $F_{A} A^{\prime}$ egyenes a modellben is meróleges $m$-re, ezért a rájuk vonatkozó tükrözés felcseréli $A$-t $C$-vel és $T_{A}$-t $T_{C}$-vel, illetve $C$-t $B$-vel és $T_{C}$-t $T_{B}$-vel. Ezért $\overline{A T_{A}}$ és $\overline{B T_{B}}$ ugyanolyan hosszú, és az átmérôre merôleges a modellben, tehát euklideszi ételemben szimmetrikusak az $l$ egyenesre, vagyis $l$ merőleges az $\overline{A B}$ szakaszra, és ez igazolja az állítást.

(P) Tegyük fel, hogy az $F_{A}$ és $F_{B}$ oldalfelezô pontokon átmenô merôleges egyenesek a határon lévő $P$ pontban metszik egymást. Ekkor az $F_{C}$-n átmenô oldalfelezố merőleges egyenes az elôzố kettô egyikével sem lehet közös sugár-, vagy hipernyalábban, mert akkor (S) és (H) szerint az elsố két egyenes is abban lenne.

Ha tehát az $F_{C}$ felezópontbeli meróleges egyenes nem menne át a $P$ ponton, akkor az egyiket a $Q$, a másikat az $R$ pontban metszené, vagyis megegyezne a $\overline{Q R}$ húrral. Ám $F_{C}$ nem lehet ezen a húron, hiszen az $F_{A} F_{B}$ egyenes elválasztja az $\overline{A B}$ és a $\overline{Q R}$ szakaszokat. 
2.17. Tétel. (Hiperbolikus magasságpont tétele [23, Theorem 3]) Hiperbolikus térben bármely trigon magasságvonalai egy nyalábhoz tartoznak.

Bizonyítás. Az $A B C \triangle$ trigon $A$, illetve $B$ csúcson átmenó $m_{A}$, illetve $m_{B}$ magasságvonala egy nyalábhoz tartozik. Azt igazoljuk, hogy a harmadik $m_{C}$ is ehhez a nyalábhoz tartozik. E nyalábok lehetséges típusai jól látszanak a Cayley-Kleinmodellben, ha annak középpontjául a $C$ csúcsot választjuk.
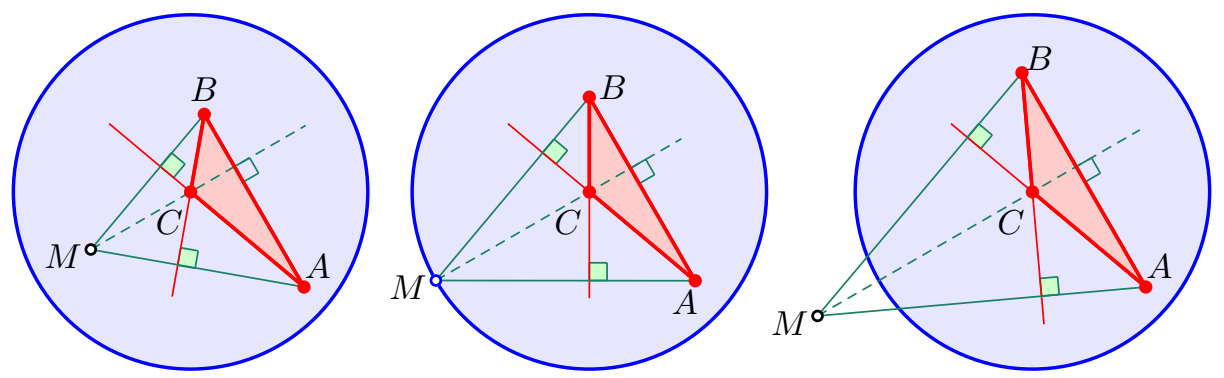

2.10. Ábra. A magasságvonalak metszéspontja a három nyalábtípus esetén

Ekkor az $m_{A}$, illetve $m_{B}$ magasságvonalak egyenesei euklideszi értelemben is merólegesek a $C B$, illetve $C A$ egyenesre. Az euklideszi síkon az $M$ metszéspontjuk létezik, ezért $M$ az $A B C \triangle$ trigon euklideszi magasságpontja. Eszerint $M C$ az euklideszi értelemben meróleges az $A B$ egyenesre. Mivel $C M$ átmegy a modell középpontján, hiperbolikus értelemben is merőleges $A B$-re, amiért a harmadik hiperbolikus magasság is átmegy $M$-en.

\subsection{A Hilbert-geometriákról}

Tekintsük $\mathbb{R}^{n}$ egy korlátos, konvex, nyílt $\mathcal{H}$ tartományát, és abban tetszőleges $X$, $Y$ pontpárokat, melyek mondjuk az $\overline{A B}$ húrra illeszkednek.

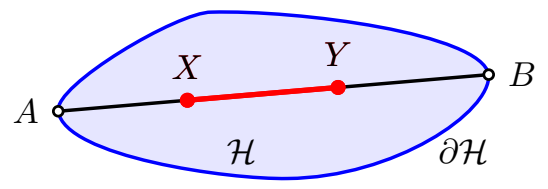

2.11. Ábra. A Hilbert-metrika definíciója

A pozitív $k$ konstanssal adott

$$
d_{\mathcal{H}}: \mathcal{H} \rightarrow \mathbb{R}, \quad d_{\mathcal{H}}(X, Y)= \begin{cases}\frac{k}{2} \ln (A, B ; X, Y), & \text { ha } X \neq Y, \\ 0, & \text { ha } X=Y,\end{cases}
$$

függvény egy metrika [30], melyet Hilbert-metrikának nevezünk. 
A $d_{\mathcal{H}}$ metrika nyilván folytonos mindkét változójában, így a $\left(\mathcal{H}, d_{\mathcal{H}}\right)$ pár egy nem kompakt, teljes metrikus teret alkot, melyben az affin egyenesek szakaszai rendelkeznek a legrövidebb út tulajdonsággal.

Ha a $\mathcal{H}$ tartomány egy $n$-szimplex belseje, akkor $\left(\mathcal{H}, d_{\mathcal{H}}\right)$ izomorf egy Minkowski-geometriával, vagyis egy $n$-dimenziós normált vektortérrel [20,34]. Ennek a megfordítása is igaz: ha a Hilbert-geometria izomorf egy normált véges dimenziós vektortérrel, akkor egy szimplex belseje [13]. Két dimenzióban ez azt jelenti, hogy ha $\mathcal{H}$ egy konvex sokszög, amelynek Hilbert-geometriája izomorf egy kétdimenziós normált vektortérrel, akkor a meghatározott metrika egy Minkowski-metrika, melynek a sokszög az indikátrixa, ám a szükséges feltétel következtében ez csak háromszög lehet $[42,9$. o.].

Ha $\partial \mathcal{H}$ nem tartalmaz két nem kollineáris szakaszt, akkor $d_{\mathcal{H}}$ teljesíti a szigorú háromszög-egyenlőtlenséget, vagyis az affin szakasz az egyetlen geodetikus.

2.18. Definíció. Az affin tér egy szigorúan konvex, korlátos, nyílt $\mathcal{H}$ tartományának a $d_{\mathcal{H}}$ Hilbert-metrikával alkotott $\left(\mathcal{H}, d_{\mathcal{H}}\right)$ párját Hilbert-geometriának nevezzük. ${ }^{6}$

Egy affin $\ell$ egyenesnek a $\mathcal{H}$ tartománnyal vett metszetét a Hilbert-geometria $\tilde{\ell}$ egyenesének nevezzük. ${ }^{7}$

Tegyük fel, hogy két különböző $X$ és $Y$ pont a $\left(\mathcal{H}, d_{\mathcal{H}}\right)$ Hilbert-geometriában tart valamely rögzített $P$ ponthoz úgy, hogy közös egyenesük végig párhuzamos a $P$ ponton átmenő $\ell$ egyenessel, amelynek pontjai a $\partial \mathcal{H}$ határon $A$ és $B$. A mozgó $X$ és $Y$ pontok egyenesének pontjai a határon legyenek $A^{*}$ és $B^{*}$ úgy, hogy $Y$ van az $A^{*}$ és $X$ között. Így a párhuzamosságra tekintettel $A^{*} \rightarrow A$ és $B^{*} \rightarrow B$ is teljesül.

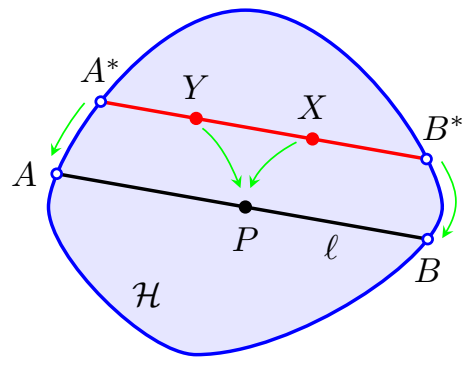

2.12. Ábra. A Hilbert-metrika Finsler függvényének kiszámításához

\footnotetext{
${ }^{6}$ A Hilbert-geometriát David Hilbert fedezte fel. Először egy levélben ír róla, amelyet Felix Kleinnek 1894-ben küldött. Klein már jóval korábban kidolgozott konstrukcióját ([28]) követi, amikor az $\mathbb{R}^{3}$ tér egy konvex tartományán kettősviszony logaritmusával definiálja pontok távolságát. Eredményeit egy évvel később az általa szerkesztett folyóiratban jelenteti meg [22]. Klein munkájára A. Cayley egy homogén koordinátákkal felírt formulája volt hatással ([8]).

${ }^{7} \mathrm{~A} \sim$ jelet csak akkor tesszük ki, ha egy szövegkörnyezetben szerepel az $\ell$ és $\tilde{\ell}$ egyenes.
} 
A Hilbert-távolság definícióját és az $\ln (1+x)$ függvény sorfejtését használva bármely $d$ Minkowski-metrikára kapjuk, hogy

$$
\begin{aligned}
d_{\mathcal{H}}(X, Y) & =\frac{k}{2} \ln \left(\frac{d\left(A^{*}, X\right)}{d\left(A^{*}, Y\right)} \cdot \frac{d\left(B^{*}, Y\right)}{d\left(B^{*}, X\right)}\right) \\
& =\frac{k}{2} \ln \left(\frac{d\left(A^{*}, Y\right)+d(X, Y)}{d\left(A^{*}, Y\right)} \cdot \frac{d\left(B^{*}, X\right)+d(X, Y)}{d\left(B^{*}, X\right)}\right) \\
& =\frac{k}{2} \ln \left[\left(1+\frac{d(X, Y)}{d\left(A^{*}, Y\right)}\right) \cdot\left(1+\frac{d(X, Y)}{d\left(B^{*}, X\right)}\right)\right] \\
& =\frac{k}{2}\left[\ln \left(1+\frac{d(X, Y)}{d\left(A^{*}, Y\right)}\right)+\ln \left(1+\frac{d(X, Y)}{d\left(B^{*}, X\right)}\right)\right] \\
& =\frac{k}{2}\left[\frac{d(X, Y)}{d\left(A^{*}, Y\right)}-\frac{1}{2} \frac{d^{2}(X, Y)}{d^{2}\left(A^{*}, Y\right)}+\cdots+\frac{d(X, Y)}{d\left(B^{*}, X\right)}-\frac{1}{2} \frac{d^{2}(X, Y)}{d^{2}\left(B^{*}, X\right)}+\ldots\right] .
\end{aligned}
$$

Ebből átosztással, majd határátmenettel adódik, hogy

$$
\lim _{X, Y \rightarrow P} \frac{d_{\mathcal{H}}(X, Y)}{d(X, Y)}=\frac{k}{2}\left[\frac{1}{d(P, A)}+\frac{1}{d(P, B)}\right]=: \Phi(P, \ell) .
$$

Ez csak a $P$ ponttól és az $\ell$ egyenestôl függ, így a Hilbert-geometria az

$$
F_{\mathcal{H}}(P, \mathbf{v})=\frac{k}{2}|\mathbf{v}|\left(\frac{1}{d(P, A)}+\frac{1}{d(P, B)}\right)
$$

Finsler-függvénnyel a $\mathcal{H}$ tartományon adott Finsler sokaság, ahol $A$ és $B$ a $\partial \mathcal{H}$ metszete a $P$ ponton átmenó, v irányvektorú egyenessel.

Ha a $P$ ponton átmenô minden $\ell$ egyenesen tekintjük a $P$-tól $1 / \Phi(P, \ell)$ távolságnál nem messzebb lévô pontokat, akkor ezek halmaza egy $P$-re centrálisan szimmetrikus szigorúan konvex $\mathcal{I}_{P}$ tartomány.

2.19. Definíció. $\mathrm{Az} \mathcal{I}_{P}$ mint indikátrix által az $\mathbb{R}^{n}$-en meghatározott $d_{\mathcal{I}}$ Minkowskimetrika adta $\left(\mathbb{R}^{n}, d_{\mathcal{I}}\right)$ Minkowski-geometriát a $P$ ponthoz tartozó lokális Minkowskigeometriának nevezzük.

Világos, hogy a $P$ ponthoz tartozó lokális Minkowski-geometria a $P$ pont elegendően kicsiny környezetében jó közelítése a Hilbert-geometriának.

A merólegesség fogalma a Birkhoff-merólegesség mintájára alakul. Az $S$ talppontja az $\ell$ egy $T$ pontja, ha $d_{\mathcal{H}}(S, T) \leq d_{\mathcal{H}}(S, X)$ minden $X \in \ell$ pontra. Mivel a távolság folytonos, nem negatív függvény, felveszi minimumát, vagyis minden $S$ pontnak minden $\ell$ egyenesen van talppontja.

2.20. Definíció. Egy $m$ egyenes meróleges ${ }^{8}$ egy ôt a $T$ pontban metsző $\ell$ egyenesre, ha $m$ minden pontjának $T$ az egyetlen talppontja. Jelölése: $m \perp \ell$.

\footnotetext{
${ }^{8} \mathrm{Ez}$ a lineáris metrikus terekre megfogalmazott Birkhoff-féle merólegesség megfelelője [3].
} 
Jegyezzük meg, hogy $m \perp \ell$ általában nem vonja maga után, hogy $\ell \perp m$, de minden pontból minden egyenesre lehet merôlegest állítani, amit most igazolunk.

2.21. Lemma. $([6,(28.11)])$ Egy $\left(\mathcal{H}, d_{\mathcal{H}}\right)$ Hilbert-geometriában egy $\tilde{m}$ egyenes akkor

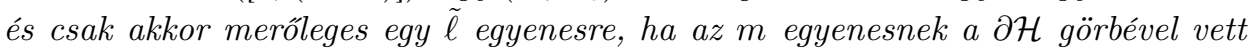
metszéspontjaiban a támaszegyenesek konkurensek az $\ell$ egyenessel.

Bizonyítás. Elegendôség. Legyenek $X$ és $Y$ az $m$ egyenes metszéspontjai a $\partial \mathcal{H}$ görbével; $t_{1}$ és $t_{2}$ ezekben a pontokban a $\partial \mathcal{H}$ görbe támaszegyenesei; ezek közös (esetleg ideális) pontja $\ell$-lel $W$; az $l$ és $m$ metszéspontja $F ; G \in \tilde{m}$ és $H \in \tilde{\ell}$ tetszóleges $F$-tôl különbözô pontok; végül $G H$ metszéspontjai $\partial \mathcal{H}$-tal és a támaszegyenesekkel $Y_{0}, Y^{\prime}, X^{\prime}, X_{0}$ (lásd a 2.13. Ábrát).

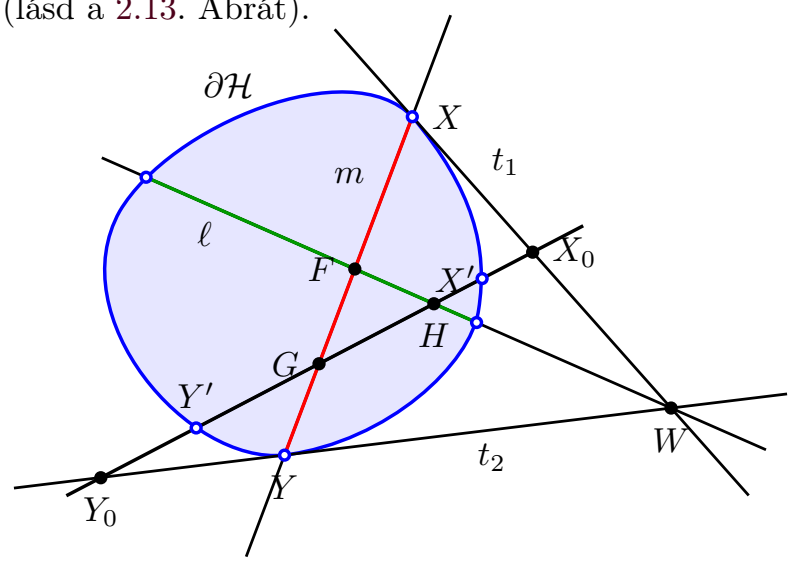

2.13. Ábra. Meróleges konstrukciója

A $G H$ és $m$ közötti $W$ centrumú perspektivitás megtartja a kettôsviszonyt, ezért $(G, F ; X, Y)=\left(G, H ; X_{0}, Y_{0}\right)$. A kettôsviszony monotonitása szerint viszont $\left(G, H ; X_{0}, Y_{0}\right)>\left(G, H ; X^{\prime}, Y^{\prime}\right)$, ezért $d_{\mathcal{H}}(G, F)>d_{\mathcal{H}}(G, H)$. Következésképpen $F$ talppont, és $m$ meróleges az $l$ egyenesre.

Szükségesség. Tegyük fel, hogy $G$ az $\ell$ egyenesen kívüli, $H$ az $\tilde{\ell}$ futó pontja, $X^{\prime}$ és $Y^{\prime}$ a $G H$ pontjai $\partial \mathcal{H}$-n. Egyszerúen látható folytonossági és konvexségi megfontolásokkal, hogy a $\mathcal{H}$ tartomány $X^{\prime}$ és $Y^{\prime}$ pontokon átmenő tartóegyeneseinek metszéspontja pontosan egyszer esik $\ell$-re. Vagyis $H$-nak pontosan egy olyan helyzete van az $\ell$ egyenesen, hogy $\ell$ és a két tartóegyenes konkurens (vagy párhuzamos). A korábbi megállapítás szerint erre a jól meghatározott $H_{0}$ pontra az $\tilde{m}$ egyenes merôleges az $\tilde{l}$ egyenesre.

Ezen konstrukcióval adott $\tilde{m}$ esetén az összes olyan $\tilde{\ell}$ egyenest megkapjuk, amelyre $\tilde{m}$ merôleges. Ha $\partial \mathcal{H}$ sima görbe, akkor a tartóegyenesek egyértelmúen meghatározott érintók, és az $\ell$ egyenesek egy nyalábot alkotnak. 
Egy adott $\ell$ egyenesre pontosan akkor lehet minden rajta kivüli $P$ pontból merólegest állítani, ha minden $X$ pontnak egyértelmüen meghatározott talppontja van $\ell$-en [6, (21.7)]; és ezzel az egyenes is egyértelmú. Az egyértelmúen meghatározott talppont létezése viszont azzal ekvivalens, hogy a körök konvexek (amiből szigorú konvexségük is következik) [6, (21.9)]. Ennek következménye, hogy pontból egyenesre a meróleges állításának unicitása ekvivalens azzal, hogy a körök (szigorúan) konvexek.

2.22. Definíció. Az $f$ egyenes $\mathcal{H}$-merőleges az $\ell$ egyenesre $\left(f \perp_{\mathcal{H}} \ell\right)$, ha $\ell \perp f$ a 2.20. Definíció értelmében.

A továbbiakban a $\mathcal{H}$-merőlegességet használjuk, és nem az eredeti 2.20. Definíció szerinti Birkhoff-merôlegességet.

A $\left(\mathcal{H}, d_{\mathcal{H}}\right)$ Hilbert-geometria metrikája kettősviszonnyal definiált, ezért minden olyan $\Phi$ kollineáció, melyre $\mathcal{H}$ invariáns, a Hilbert-geometria izometriáját adja. Ennek fordítottja is igaz [6, (22.10)]: a Hilbert-geometria minden egyes izometriája a projektív tér olyan kollineációjának megszorítása a $\mathcal{H}$ tartományra, amely a $\mathcal{H}$ tartományt invariánsan hagyja.

2.23. Definíció. Ha egy involutorikus izometriának egyetlen fixpontja van - a pont-képpont párok $C$ felezốpontja —, akkor a $C$-re vonatkozó centrális tükrözésnek nevezzük. Ha a fixpontok egy $\ell$ egyenest alkotnak, akkor az $\ell$-re vonatkozó tengelyes tükrözésról beszélünk $[6,127$. o.].

Ha egy nem identikus izometria egy $\ell$ egyenest pontonként fixen hagy, akkor ez az $\ell$ tengelyre vonatkozó tükrözés [6, (23.8)]. Ha pedig létezik az $\ell$ egyenesre vonatkozó tükrözés, akkor $m \perp \ell$ maga után vonja, hogy $\ell \perp m[6,(23.9)]$.

2.24. Definíció. Legyen $A$ és $A^{\prime}$ két különbözô pont. Kétpontekvidisztáns alakzatnak nevezzük azon $X$ pontok $\mathcal{F}_{A, A^{\prime}}$ halmazát, amelyekre $d_{\mathcal{H}}(A, X)=d_{\mathcal{H}}\left(A^{\prime}, X\right)$.

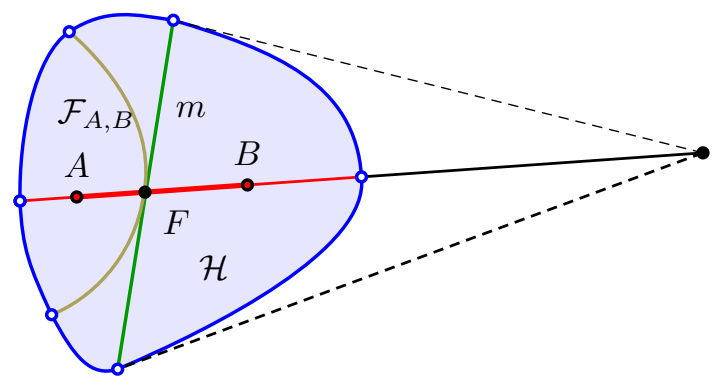

2.14. Ábra. Felezô merőleges és kétpontekvidisztáns görbe

Egy kétdimenziós Hilbert-geometriában is beszélhetünk egy szakasz felezô merőleges egyenesérôl, ám ez általában nem a kétpontekvidisztáns alakzat. Ha egy 
$\ell$ egyenesre létezik $\tau_{\ell}$ tükrözés, és a különbözó $A$ és $B$ pontokra $\tau_{\ell}(A)=B$, akkor e két pont ekvidisztáns alakzata az $\ell$ (melyre ekkor $A B$ meróleges) $[6,(23.5)]$. Ha minden egyenesre létezik tükrözés, akkor a geometria hiperbolikus [6, (29.3)], amiért a szakaszfelezô merőleges egyenesek és a kétpontekvidisztáns görbék egybeesnek.

Hilbert-geometriában többféle módon is bevezethetô görbület.

A Riemann-sokaságok metszetgörbületét általánosítja a Finsler-sokaságokra bevezetett zászlógörbület fogalma. Megállapítható, hogy egy Hilbert-geometria zászlógörbülete konstans -1. A Funk-Berwald-tétel a Finsler-geometria egyik alapvetô eredménye $([2,15])$ : Legyen $F$ egy differenciálható és szigorúan konvex Finslermetrika az $\mathbb{R}^{n}$ egy korlátos, nyilt, konvex $\mathcal{H}$ tartományán. Tegyük fel, hogy $F$ teljes, zászlógörbülete pedig konstans -1 , továbbá a $d_{\mathcal{F}}$ távolságfüggvénye projektiv metrikát határoz meg. Ekkor d Hilbert-metrika $\mathcal{H}-n$.

A Busemann-féle görbületfogalom inkább minőségi tulajdonságot fejez ki, szemben a differenciálgeometriában szokásos mennyiségivel. Ez egyike a metrikus terek görbület-fogalmainak, és [5, 173. o.] alapján kellően sima Riemann-sokaságokban ekvivalens az Alexandrov-féle görbülettel.

2.25. Definíció. Azt mondjuk, hogy egy $\left(\mathcal{H}, d_{\mathcal{H}}\right)$ Hilbert-geometriának a $P$ pontban nempozitív görbülete van, ha $P$-nek van olyan környezete, amelynek minden $A, B, C$ pontjára, illetve az $\overline{A B}$ és $\overline{A C}$ szakasz $d_{\mathcal{H}}$ metrika szerinti $F_{C}$ és $F_{B}$ felezôpontjára

$$
2 d_{\mathcal{H}}\left(F_{C}, F_{B}\right) \leq d_{\mathcal{H}}(B, C) .
$$

Azt mondjuk, hogy $P$-ben a görbület nemnegatív, ha a fordított irányú egyenlőtlenség áll fenn. A görbületet $P$-ben indetermináltnak nevezzük, ha nem nempozitív, és nem nemnegatív $P$-ben.

Ismeretes [32], hogy ha a $\mathcal{H}$ Hilbert-geometria $P$ pontjában a görbület nempozitív, akkor $P$ a $\mathcal{H}$ projektív centruma, és ennek fordítottja is igaz, sôt nincsen nemnegatív görbületú pont sem, és ha minden pontban nempozitív a görbület, akkor a geometria hiperbolikus.

Amennyiben $\partial \mathcal{H}$ egy ellipszis, akkor két érintő $W$ metszéspontja az érintési pontokat összekötô $m$ egyenes pólusa, és az $m$ tetszôleges pontjának polárisa átmegy $W$-n, emiatt a merólegesség szimmetrikus [6, (28.12)]. Fordítva, a merólegesség szimmetriája a Hilbert-geometriák közül pontosan az ellipszoiddal megadottakban, vagyis a hiperbolikus geometriában teljesül [26, Theorem 2].

A lokális Minkowski-metrika szerinti merôlegesség megegyezik a Hilbertmetrika szerinti merôlegességgel ([25, Theorem 2]), amiért ha egy Hilbert-geometria minden pontjában lokálisan euklideszi, akkor hiperbolikus [25]. 
Egy Hilbert-geometriában akkor és csak akkor van tengelyes tükrözés minden hipersíkra vonatkozóan, ha a geometria hiperbolikus. A szükséges feltétel élesíthetô: ha csak egyetlen pontra illeszkedô hipersíkokra léteznek a tükrözések, már akkor is hiperbolikus a geometria [6, (29.2) második állítása]. Ugyanez igaz a pontra vonatkozó tükrözésre is [32].

A Hilbert-geometria lokálisan Minkowski-geometria, így az

$$
A(\mathcal{B})=\iint_{\mathcal{B}} \sigma\left(x_{1}, x_{2}\right) d x_{1} d x_{2}, \text { ahol } \sigma\left(x_{1}, x_{2}\right)=\pi\left[\int_{-\pi / 2}^{\pi / 2} \Phi^{-2}\left(\left(x_{1}, x_{2}\right), l\right) d \omega\right]^{-1}
$$

formulával definiálhatjuk bármely $\mathcal{B}$ tartomány $\mathcal{H}$-területét. A hiperbolikus geometriában minden aszimptotikus ${ }^{9}$ háromszög $\mathcal{H}$-területe $\pi$, ahogyan az a Poincarémodellből azonnal látható, és valójában a szögdefektus. Ez a tulajdonság karakterizálja a hiperbolikus geometriát a Hilbert-geometriák között [9].

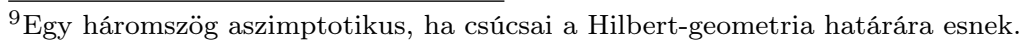




\section{Előkészületek}

\subsection{Néhány technikai lemma}

Legyenek a $\left(\mathcal{H}, d_{\mathcal{H}}\right)$-val adott Hilbert-geometriában $A, B$ és $C$ kollineáris pontok, és legyen $A B \cap \partial \mathcal{H}=\{P, Q\}$ úgy, hogy $A$ a $P$ és $B$ között van. Tekintsük az $A B$ egyenesnek egy olyan affin koordináta-rendszerét, hogy $P$ koordinátája 0 , és $A$ koordinátája 1. Legyenek ebben a koordináta-rendszerben $q, b$ és $c$ a $Q, B$ és $C$ pontok koordinátái a $q>b>1$ és $0<c<q$ feltételekkel.

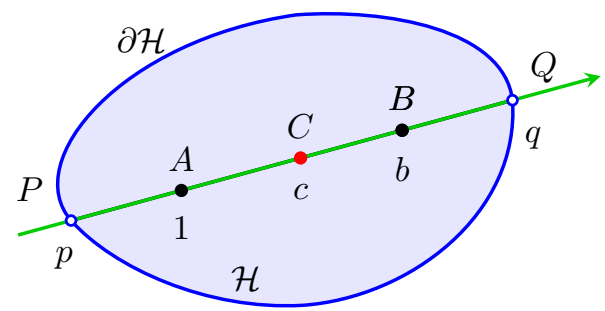

3.1. Ábra. A hiperbolikus osztóviszony kifejezése koordinátákkal

3.1. Lemma. [KKc, Lemma 2.3] A hiperbolikus metrikus osztóviszonyra

$$
\langle A, B ; C\rangle=\frac{c-b}{(c-1) \sqrt{b}} \sqrt{1+\frac{b-1}{q-b}} .
$$

Bizonyítás. A hiperbolikus metrikus osztóviszony 2.13. Definíciója szerint

$$
\begin{aligned}
|\langle A, B ; C\rangle| & =\frac{\operatorname{sh}\left(\frac{\operatorname{sign}(c-b)}{2} \ln \frac{c(q-b)}{b(q-c)}\right)}{\operatorname{sh}\left(\frac{\operatorname{sign}(1-c)}{2} \ln \frac{q-c}{c(q-1)}\right)}=\frac{\left(\frac{c(q-b)}{b(q-c)}\right)^{\frac{\operatorname{sign}(c-b)}{2}}-\left(\frac{b(q-c)}{c(q-b)}\right)^{\frac{\operatorname{sign}(c-b)}{2}}}{\left(\frac{q-c}{c(q-1)}\right)^{\frac{\operatorname{sign}(1-c)}{2}}-\left(\frac{c(q-1)}{q-c}\right)^{\frac{\operatorname{sign}(1-c)}{2}}} \\
& =\frac{\left((c(q-b))^{\operatorname{sign}(c-b)}-(b(q-c))^{\operatorname{sign}(c-b)}\right)(c(q-1)(q-c))^{\frac{\operatorname{sign}(1-c)}{2}}}{\left((q-c)^{\operatorname{sign}(1-c)}-(c(q-1))^{\operatorname{sign}(1-c)}\right)(b(q-c) c(q-b))^{\frac{\operatorname{sign}(c-b)}{2}}} .
\end{aligned}
$$

Ebben három esetet kell megvizsgálnunk: $0<c<1,1<c<b$ és $b<c<q$. A $0<c<1$ esetében $\operatorname{sign}(1-c)=1$, továbbá $\operatorname{sign}(c-b)=-1$, és ezért

$$
\begin{aligned}
|\langle A, B ; C\rangle| & =\frac{\left((c(q-b))^{-1}-(b(q-c))^{-1}\right)(c(q-1)(q-c))^{1 / 2}}{((q-c)-c(q-1))(b(q-c) c(q-b))^{-1 / 2}} \\
& =\frac{(b-c) q(q-1)^{1 / 2}}{q(1-c)(b(q-b))^{1 / 2}}=\frac{(b-c)}{(1-c) \sqrt{b}} \sqrt{\frac{q-1}{q-b}} .
\end{aligned}
$$


Ha $1<c<b$, következésképpen $\operatorname{sign}(1-c)=-1$, továbbá $\operatorname{sign}(c-b)=-1$, akkor

$$
\begin{aligned}
|\langle A, B ; C\rangle| & =\frac{\left((c(q-b))^{-1}-(b(q-c))^{-1}\right)(c(q-1)(q-c))^{-1 / 2}}{\left((q-c)^{-1}-(c(q-1))^{-1}\right)(b(q-c) c(q-b))^{-1 / 2}} \\
& =\frac{(b(q-c)-c(q-b))(c(q-1)(q-c))^{1 / 2}}{(c(q-1)-(q-c))(b(q-c) c(q-b))^{1 / 2}} \\
& =\frac{(b-c)(q-1)^{1 / 2}}{(c-1) \sqrt{b}(q-b)^{1 / 2}}=\frac{(b-c)}{(c-1) \sqrt{b}} \sqrt{1+\frac{b-1}{q-b}} .
\end{aligned}
$$

Ha $b<c<q$, és így $\operatorname{sign}(1-c)=-1$, továbbá $\operatorname{sign}(c-b)=1$, akkor

$$
\begin{aligned}
|\langle A, B ; \mathbf{C}\rangle| & =\frac{(c(q-b)-b(q-c))(c(q-1)(q-c))^{-1 / 2}}{\left((q-c)^{-1}-(c(q-1))^{-1}\right)(b(q-c) c(q-b))^{1 / 2}} \\
& =\frac{(c(q-b)-b(q-c))(c(q-1)(q-c))^{1 / 2}}{(c(q-1)-(q-c))(b(q-c) c(q-b))^{1 / 2}} \\
& =\frac{(c-b)(q-1)^{1 / 2}}{(c-1)(b(q-b))^{1 / 2}}=\frac{(c-b)}{(c-1) \sqrt{b}} \sqrt{1+\frac{b-1}{q-b}} .
\end{aligned}
$$

Mindhárom eset megvizsgálásával a lemmát igazoltuk.

Ahogyan arra a 2.13. Definíciónál már utaltunk, a (3.1) következménye, hogy egy egyenesen két pontot rögzítve kölcsönösen egyértelmú megfeleltetést kapunk az egyenes $A$-tól és $B$-tól különbözô pontjai és $\mathbb{R} \backslash\{-1,0,1\}$ között $(-1$ az ideális pontnak felel meg).

A következô, differenciálható görbékre vonatkozó technikai lemmákhoz szükséges alapvető differenciálgeometriai ismeretek a [29] könyvben találhatók.

3.2. Lemma. ([KKh, Lemma 3.4]) Legyenek $\mathbf{r}, \mathbf{p}:(-\varepsilon, \varepsilon) \rightarrow \mathbb{R}^{2}$ kétszer folytonosan differenciálható görbék kis $\varepsilon>0$ értékekre úgy, hogy $\mathbf{p}(\tau)=p(\tau) \mathbf{u}_{\tau}$, és $\mathbf{r}(\tau)=$ $r(\tau) \mathbf{u}_{\tau}$, ahol $p, r:(-\varepsilon, \varepsilon) \rightarrow \mathbb{R}_{+}$, továbbá az $r(\tau) / p(\tau)$ az 1 minimumértéket kizárólag $a \tau=0$ helyen veszi fel.

Ekkor az $\mathbf{r}$, illetve $\mathbf{p}$ görbék $\mathbf{r}(\tau)$, illetve $\mathbf{p}(\tau)$ pontbeli érintö egyenesei egy olyan $\mathbf{m}(\tau)$ pontban metszik egymást, amely a $\mathbf{p}(0)$ ponthoz tart, amint $\tau \rightarrow 0$, mégpedig úgy, hogy ez az $\overline{\mathbf{O p}(\tau)}$ egyenesnek ugyanazon az oldalán van, mint a $\mathbf{p}(0)$.

Bizonyítás. Legyen $\lambda:(-\varepsilon, \varepsilon) \rightarrow[1, \infty)$ olyan, hogy $r(\tau)=\lambda(\tau) p(\tau)$. Akkor ez egyértelmúen a 0 -ban veszi fel az 1 minimumértéket. Így $\dot{\lambda}(0)=0$, és $\ddot{\lambda}(0)>0$. Ez pedig azt jelenti, hogy $\lambda$ szigorúan monoton csökkenő $\tau<0$ esetén, és szigorúan monoton növekvô $\tau>0$ esetén. 
Kozma J.

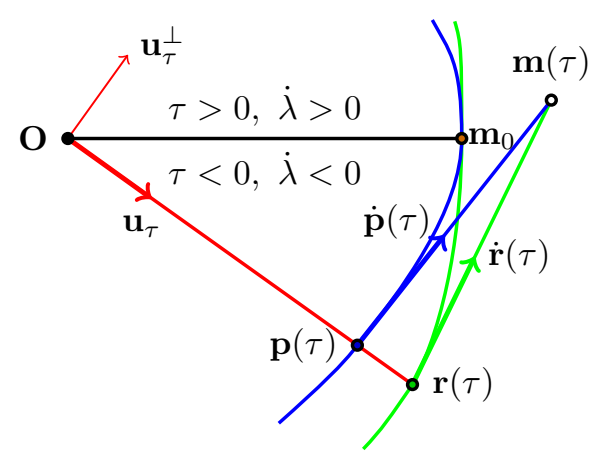

3.2. Ábra. Az érintô egyenesek metszése

Minthogy $\dot{\mathbf{r}}=\lambda \dot{\mathbf{p}}+\dot{\lambda} \mathbf{p}, \dot{\mathbf{p}} \| \dot{\mathbf{r}}$ akkor és csak akkor teljesül, ha $\dot{\lambda}=0$, így az $\mathbf{m}(\tau)$ egyértelmúen meghatározott minden $\tau \neq 0$ értékre.

Láthatóan fennáll

$$
\pm|\mathbf{m}-\mathbf{p}| \frac{\dot{\mathbf{p}}}{|\dot{\mathbf{p}}|}+\mathbf{p}=\mathbf{m}= \pm|\mathbf{m}-\mathbf{r}| \frac{\dot{\mathbf{r}}}{|\dot{\mathbf{r}}|}+\mathbf{r}
$$

vagyis $\pm|\mathbf{m}-\mathbf{p}\|\dot{\mathbf{r}}|\dot{\mathbf{p}}+| \dot{\mathbf{r}}\| \dot{\mathbf{p}}| \mathbf{p}= \pm|\mathbf{m}-\mathbf{r}\|\dot{\mathbf{p}}|\dot{\mathbf{r}}+| \dot{\mathbf{p}}\| \dot{\mathbf{r}}| \mathbf{r}$.

Mivel $\dot{\mathbf{p}}=\dot{p} \mathbf{u}_{\tau}+p \mathbf{u}_{\tau}^{\perp} \dot{\mathbf{r}}=\dot{r} \mathbf{u}_{\tau}+r \mathbf{u}_{\tau}^{\perp}$ és $\mathbf{u}_{\tau} \perp \mathbf{u}_{\tau}^{\perp}$ teljesül, azt kapjuk, hogy

$$
\begin{aligned}
|\mathbf{m}-\mathbf{p} \| \dot{\mathbf{r}}| p & =|\mathbf{m}-\mathbf{r} \| \dot{\mathbf{p}}| r \\
\pm|\mathbf{m}-\mathbf{p}\|\dot{\mathbf{r}}|\dot{p}+p| \dot{\mathbf{p}}\| \dot{\mathbf{r}}| & = \pm|\mathbf{m}-\mathbf{r}\|\dot{\mathbf{p}}|\dot{r}+r| \dot{\mathbf{r}}\| \dot{\mathbf{p}}|
\end{aligned}
$$

A $p$-vel megszorzott (3.4) egyenlőségbe a (3.3) szerinti behelyettesítés azt adja, hogy $\pm\left|\mathbf{m}-\mathbf{r}\left\|\dot{\mathbf{p}}\left|r \dot{p}+p^{2}\right| \dot{\mathbf{p}}\right\| \dot{\mathbf{r}}\right|= \pm|\mathbf{m}-\mathbf{r}||\dot{\mathbf{p}}| p \dot{r}+p r|\dot{\mathbf{r}} \| \dot{\mathbf{p}}|$, így

$$
\pm|\mathbf{m}-\mathbf{r}|=\frac{p|\dot{\mathbf{r}}|(r-p)}{r \dot{p}-p \dot{r}}=\frac{|\dot{\mathbf{r}}| p^{2}(\lambda-1)}{\lambda p \dot{p}-p(\dot{\lambda} p+\lambda \dot{p})}=|\dot{\mathbf{r}}| \frac{\lambda-1}{-\dot{\lambda}} .
$$

A l'Hôspital-szabály szerint ez a $\lim _{\tau \rightarrow 0}|\mathbf{m}(\tau)-\mathbf{r}(\tau)|=0$ egyenlóséghez vezet.

Másrészt felhasználva a (3.3) egyenlőséget, továbbá a (3.5) egyenlőség (3.2)-be való behelyettesítése azt eredményezi, hogy

$$
\frac{\lambda(\lambda-1)}{-\dot{\lambda}} \dot{\mathbf{p}}+\mathbf{p}=\mathbf{m}=\frac{\lambda-1}{-\dot{\lambda}} \dot{\mathbf{r}}+\mathbf{r} .
$$

Tekintetbe véve, hogy $\lambda \geq 1$, ez utóbbi azt vonja maga után, hogy $\mathbf{m}$ az $\mathbf{O p}(\tau)$, illetve $\operatorname{Or}(\tau)$ egyenesnek ugyanazon az oldalán van, mint $\mathbf{m}(0)=\mathbf{r}(0)=\mathbf{p}(0)$.

Ezzel a bizonyítás teljes. 
3.3. Lemma. ([Km, Lemma 2.4]) Legyenek $\mathbf{r}, \mathbf{p}:[0 ; 1] \rightarrow \mathbb{R}^{2}$ folytonosan differenciálható görbék, melyek deriváltja nem tünik el.

(1) $H a($ i) $\mathbf{r} \| \mathbf{p}$, (ii) $\dot{\mathbf{r}} \| \dot{\mathbf{p}}$, és ezek a görbék metszik egymást, akkor $\mathbf{r}=\mathbf{p}$.

(2) Ha $\dot{\mathbf{r}}(0) \| \dot{\mathbf{p}}(0)$, és $\dot{\mathbf{r}}(1) \| \dot{\mathbf{p}}(1)$, akkor létezik egy olyan $t_{0} \in(0,1)$ érték, amelyre $\dot{\mathbf{r}}\left(t_{0}\right) \| \dot{\mathbf{p}}\left(t_{0}\right)$.

Bizonyítás. (1) Az (i) és (ii) feltételekból következik olyan differenciálható, nem eltúnó valós $\lambda$, illetve $\mu$ függvények létezése, hogy $\mathbf{r}=\lambda \mathbf{p}$, illetve $\dot{\mathbf{r}}=\mu \dot{\mathbf{p}}$ teljesül. Az első egyenlőség deriváltjába behelyettesítve a másodikat, azt kapjuk, hogy $\mu \dot{\mathbf{p}}=$ $\dot{\lambda} \mathbf{p}+\lambda \dot{\mathbf{p}}$, ezért $\mathbf{0}=\dot{\lambda} \mathbf{p}+(\lambda-\mu) \dot{\mathbf{p}}$. Ha $\mathbf{p} \nVdash \dot{\mathbf{p}}$, akkor ebból $\dot{\lambda}=0$ adódik, és ez maga után vonja az állítást. Ha $\mathbf{p} \| \dot{\mathbf{p}}$, akkor $\mathbf{p}$ egy szakasz, így kapjuk az állítást.

(2) Elegendő a középértéktételt alkalmazni az $\arccos \frac{\langle\dot{\mathbf{r}}, \dot{\mathbf{p}}\rangle}{|\dot{\mathbf{r}}| \cdot|\dot{\mathbf{p}}|}$ függvényre.

\subsection{Ellipszisek egy Segre-típusú jellemzése}

Az ellipsziskarakterizációs tételünk a következô konfigurációra vonatkozik.

3.4. Konfiguráció. A $\partial \mathcal{H}$ oválison lévő különbözô $E_{i}(i=1,2,3)$ pontokra jelölje $\ell_{i}$ az $E_{j} E_{k}$ egyenest ( $i, j, k$ különbözók), $t_{i}^{\mathcal{H}}$ pedig a $\mathcal{H}$ érintójét az $E_{i}$ ponton keresztül. Jelölje továbbá $f_{i}^{\mathcal{H}}$ azt az egyenest, amelyet az $\ell_{j}=E_{k} E_{i}$ és $\ell_{k}=E_{i} E_{j}$ egyenesek $(j, k=1,2,3)$ harmonikusan választanak el $t_{i}^{\mathcal{H}}$-tól.

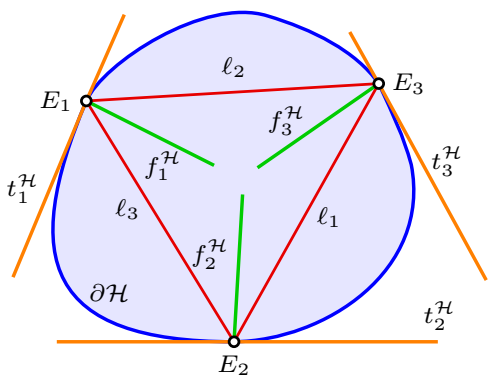

3.3. Ábra. Konfiguráció ellipsziskarakterizációhoz

3.5. Tétel. [KKh, Theorem 4.2] Tekintsünk egy 3.4. Konfigurációt.

(i) $H a \mathcal{H}$ egy ellipszis, akkor az $f_{1}^{\mathcal{H}}, f_{2}^{\mathcal{H}}, f_{3}^{\mathcal{H}}$ egyenesek konkurensek.

(ii) $H a$ az $f_{1}^{\mathcal{H}}, f_{2}^{\mathcal{H}}, f_{3}^{\mathcal{H}}$ egy nyaláb egyenesei az $E_{1}, E_{2}, E_{3} \in \partial \mathcal{H}$ pontok tetszóleges választása esetén, akkor $\mathcal{H}$ egy ellipszis.

Érdemes megjegyezni, hogy ezen tétel duálisa - a Ceva- és a Menelaosztétel révén - ekvivalens Segre egy eredményével [39, §3], amely bár véges testekre vonatkozik, de csak a test kommutativitását használja, amint arra [27, 6.15. Tétel] is rámutat. 
Bizonyítás. Elôször is jegyezzük meg, hogy a projektivitások azon túl, hogy megtartják a kettősviszonyt, differenciálhatók is, így egy görbe érintőjét mindig a képgörbe érintôjébe viszik.

(i) Egy alkalmas affinitással egy $\mathcal{E}$ ellipszis átvihetô egy $\mathcal{D}$ körlemezbe. Minthogy a projektív csoport háromszorosan tranzitíven hat minden kúpszeleten ${ }^{10}$, ezért feltehetjük, hogy $E_{1}, E_{2}, E_{3}$ egy szabályos háromszöget határoz meg a $\partial \mathcal{D}$ körön. Ezért az $f_{1}^{\mathcal{D}}, f_{2}^{\mathcal{D}}, f_{3}^{\mathcal{D}}$ egyenesek nyilvánvalóan a $\mathcal{D}$ középpontjában metszik egymást, ami bizonyítja a (i) állítást.

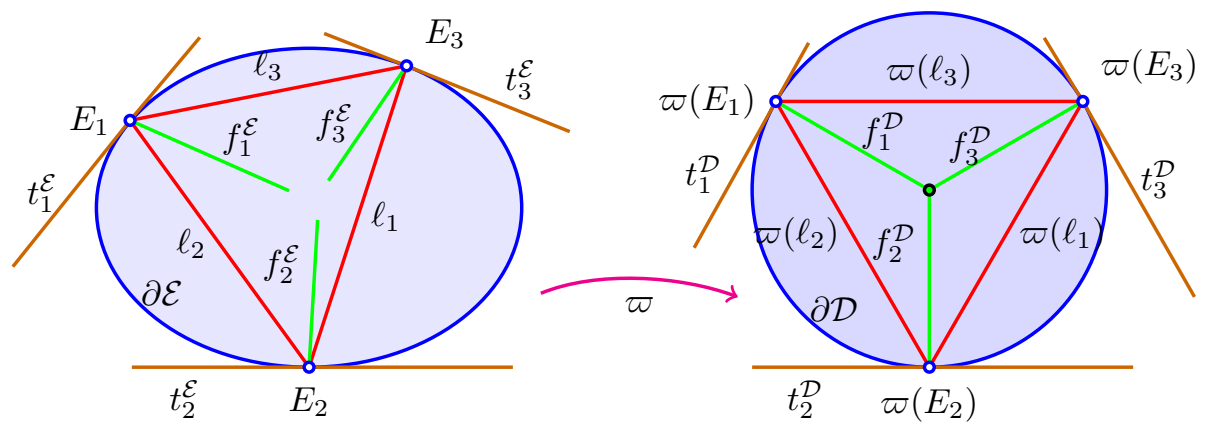

3.4. Ábra. A $\varpi$ az $\mathcal{E}$ ellipszistartományt a $\mathcal{D}$ körlemezbe, az $E_{1} E_{2} E_{3} \triangle$ háromszöget szabályos háromszögbe transzformálja.

(ii) A feltétel változatlan marad, amennyiben a konfigurációt egy projektív leképezéssel transzformáljuk, ezért a továbbiakban feltesszük, hogy a rögzített $E_{1}, E_{2}$ és $E_{3}$, valamint az $F:=f_{1}^{\mathcal{H}} \cap f_{2}^{\mathcal{H}} \cap f_{3}^{\mathcal{H}}$ pont koordinátái a következók: $E_{1}=(0,1)$, $E_{2}=(0,-1), E_{3}=(1,0)$ és $F=(1 / 2,0)$.

Ekkor az $f_{1}^{\mathcal{H}}, f_{2}^{\mathcal{H}}$ és $f_{3}^{\mathcal{H}}$ egyenesek egyértelmúen meghatározottak, és az $\left(\ell_{1}, \ell_{2} ; t_{3}^{\mathcal{H}}, f_{3}^{\mathcal{H}}\right)=\left(\ell_{2}, \ell_{3} ; t_{1}^{\mathcal{H}}, f_{1}^{\mathcal{H}}\right)=\left(\ell_{3}, \ell_{1} ; t_{2}^{\mathcal{H}}, f_{2}^{\mathcal{H}}\right)=-1$ feltételekből rendre az $y=1, y=-1$ és $x=1$ egyenleteket kapjuk a $t_{1}^{\mathcal{H}}, t_{2}^{\mathcal{H}}$ és $t_{3}^{\mathcal{H}}$ érintő egyenesekre.

Válasszunk ezután egy általános $H \in \partial \mathcal{H}$ pontot úgy, hogy különbözzön az $E_{1}, E_{2}$ pontoktól. Legyen továbbá $\partial \mathcal{E}_{H}$ az az egyértelmúen meghatározott ellipszis, amely átmegy az $E_{1}, E_{2}$ és $H$ pontokon, valamint $t_{1}^{\mathcal{E}}:=t_{1}^{\mathcal{H}}$ és $t_{2}^{\mathcal{E}}:=t_{2}^{\mathcal{H}}$ az érintői.

További jelöléseket vezetünk be (lásd a 3.5. Ábrát):

(1) $t_{H}^{\mathcal{H}}$ a $\mathcal{H}$ érintô egyenese a $H$ pontban;

(2) $\tilde{\ell}_{i}$ a $H E_{i}$ egyenes $(i=1,2) ; \tilde{\ell}_{3}$ az $E_{1} E_{2}$ egyenes;

(3) $f_{i}^{\mathcal{H}}$ az $E_{i}(i=1,2)$ ponton átmenô azon egyenes, amelyre $-1=\left(\bar{\ell}_{j}, \bar{\ell}_{k} ; t_{i}^{\mathcal{H}}, f_{i}^{\mathcal{H}}\right)$, ahol $\{i, j, k\}=\{1,2,3\}$

(4) $f_{H}^{\mathcal{H}}$ az az egyenes a $H$ ponton keresztül, amelyre $-1=\left(\bar{\ell}_{1}, \bar{\ell}_{2} ; t_{H}^{\mathcal{H}}, f_{H}^{\mathcal{H}}\right)$.

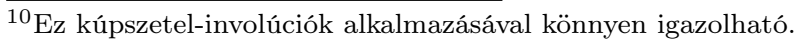


Analóg módon bevezetjük ugyanezeket az egyeneseket az $\mathcal{E}_{H}$ ellipszis esetében is, a $\mathcal{H}$ felsó indexet minden esetben $\mathcal{E}$-re cserélve.

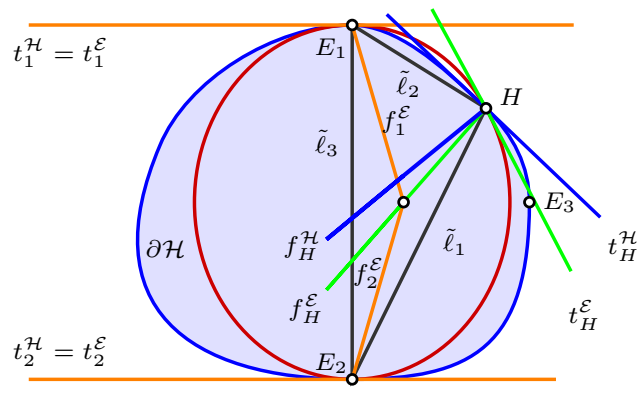

3.5. Ábra. Harmonikus sugárnyalábok bevezetése

Mivel két közös pontban az érintók megegyeznek: $t_{1}^{\mathcal{E}}=t_{1}^{\mathcal{H}}$, és $t_{2}^{\mathcal{E}}=t_{2}^{\mathcal{H}}$, ezért e pontokban a harmonikus negyedikek is megegyeznek: $f_{i}^{\mathcal{H}}=f_{i}^{\mathcal{E}}(i=1,2)$.

Minthogy az $f_{1}^{\mathcal{E}}, f_{2}^{\mathcal{E}}$ és $f_{H}^{\mathcal{E}}$ egyenesek a (i) szerint egy nyalábhoz tartoznak, továbbá az $f_{1}^{\mathcal{H}}, f_{2}^{\mathcal{H}}$ és $f_{H}^{\mathcal{H}}$ egyenesek is egy nyalábhoz tartoznak a (ii) feltétel szerint, arra következtethetünk, hogy az $f_{H}^{\mathcal{H}}$ és $f_{H}^{\mathcal{E}}$ egyenesek a $H$ ponton kívül az $f_{1}^{\mathcal{H}} \cap f_{2}^{\mathcal{H}}=$ $f_{1}^{\mathcal{E}} \cap f_{2}^{\mathcal{E}}$ pontban is metszik egymást, amiért meg kell egyezniük.

Így azt kaptuk, hogy $t_{H}^{\mathcal{H}}=t_{H}^{\mathcal{E}}$. Ez ad értelmet a következô jelölések bevezetésének: $t_{i}:=t_{i}^{\mathcal{E}}=t_{i}^{\mathcal{H}}(i=1,2)$ és $t_{H}:=t_{H}^{\mathcal{E}}=t_{H}^{\mathcal{H}}$.

Legyen $r:(-\pi, \pi] \rightarrow \mathbb{R}_{+}$egy olyan leképezés, amelyre az $r(\varphi) \mathbf{u}_{\varphi}$ helyvektor $H_{\varphi}$ végpontja az $\partial \mathcal{H}$, görbén van minden $\varphi \in(-\pi, \pi]$ esetén.

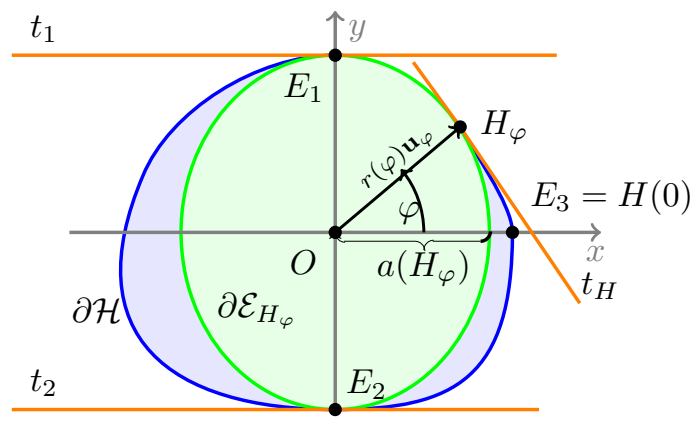

3.6. Ábra. A $\partial \mathcal{H}$ paraméterezése

Ekkor a $\partial \mathcal{H}$ érintővektora a $\varphi$ paraméterú $H_{\varphi}$ pontban $\dot{r}(\varphi) \mathbf{u}_{\varphi}+r(\varphi) \mathbf{u}_{\varphi}^{\perp}$, amely párhuzamos a $H_{\varphi}$ ponton átmenő, egyértelmü $\partial \mathcal{E}_{H_{\varphi}}$ ellipszis érintőjével.

Az $\partial \mathcal{E}_{H_{\varphi}}$ ellipszis átmegy az $E_{1}, E_{2}, H_{\varphi}$ pontokon, és az érintői az $E_{1}$, illetve $E_{2}$ pontban $t_{1}$, illetve $t_{2}$, ezért egyenlete $\frac{x^{2}}{a^{2}}+y^{2}=1$ valamely $a=a\left(H_{\varphi}\right)$ értékre. 
Ebbe az egyenletbe beírva a $H_{\varphi}$ pont koordinátáit, azt kapjuk, hogy

$$
1=r^{2}(\varphi)\left(\frac{\cos ^{2} \varphi}{a^{2}}+\sin ^{2} \varphi\right), \text { vagyis } a^{2}=\frac{r^{2}(\varphi) \cos ^{2} \varphi}{1-r^{2}(\varphi) \sin ^{2} \varphi} .
$$

Másrészt az ellipszis érintőjének meredeksége az $(x, y)$ pontban $d y / d x=$ $-x / y a^{2}$, és ennek értéke a $H_{\varphi}$ pontban

$$
\frac{\dot{r}(\varphi) \sin \varphi+r(\varphi) \cos \varphi}{\dot{r}(\varphi) \cos \varphi-r(\varphi) \sin \varphi}=\frac{d y}{d x}=\frac{-x}{y a^{2}}=\frac{-\cos \varphi}{a^{2} \sin \varphi} .
$$

Eszerint

$$
\frac{\dot{r}(\varphi)}{r(\varphi)}=\frac{\left(1-a^{2}\right) \sin \varphi \cos \varphi}{a^{2} \sin ^{2} \varphi+\cos ^{2} \varphi}=\frac{\left(1-\frac{r^{2}(\varphi) \cos ^{2} \varphi}{1-r^{2}(\varphi) \sin ^{2} \varphi}\right) \sin \varphi \cos \varphi}{\frac{r^{2}(\varphi) \cos ^{2} \varphi}{1-r^{2}(\varphi) \sin ^{2} \varphi} \sin ^{2} \varphi+\cos ^{2} \varphi}=\left(1-r^{2}(\varphi)\right) \operatorname{tg} \varphi .
$$

Minden olyan $\varphi$ helyen, ahol $r(\varphi) \neq 1$, ebből azt kapjuk, hogy

$$
\frac{\dot{r}(\varphi)}{r(\varphi)\left(1-r^{2}(\varphi)\right)}=\operatorname{tg} \varphi
$$

Ebből integrálással adódik, hogy

$$
\frac{-1}{2} \ln \frac{\left|1-r^{2}(\varphi)\right|}{r^{2}(\varphi)}=-\ln |\cos \varphi|+c_{0}
$$

valamely $c_{0}$ állandóval, amiből

$$
r(\varphi)=\frac{1}{\sqrt{1 \pm c_{1} \cos ^{2} \varphi}}
$$

következik valamely $c_{1}$ konstansra. Ha ezt behelyettesítjük a (3.6) összefüggésbe, akkor $a^{2}\left(1 \pm c_{1}\right)=1$ adódik, és így a ugyanaz az állandó minden $\partial \mathcal{E}_{H_{\varphi}}$ ellipszis esetére, amelyek ezért egyetlen rögzített $\partial \mathcal{E}$ ellipszissel egyeznek meg. Ez azt jelenti, hogy $\partial \mathcal{H}$ egy részhalmaza a $\left(1 \pm c_{1}\right) \cdot x^{2}+y^{2}=1$ egyenletú $\partial \mathcal{E}$ ellipszisnek.

Vegyük azonban figyelembe, hogy $\partial \mathcal{H}$ tartalmaza az $E_{3}=(1,0)$ pontot is, következésképpen $c_{1}=0$, és így $\partial \mathcal{H}$ az origó középpontú egységkör. Ez igazolja az (ii) állítást.

Megjegyezzük, hogy a [KKp] cikk tovább fúzi ezen eredménynek az egymásba írt háromszögek perspektivitására vonatkozó tartalmát. 


\subsection{Ceva típusú tétel oválisba írt háromszögekre}

A 3.4. Konfiguráció bôvítésén fogunk dolgozni.

3.6. Konfiguráció. A 3.4. Konfigurációt az alábbiakkal bővítjük.

Legyen az $X_{i}$ pont a $\sigma_{i}=\overline{E_{j} E_{k}}$ nyílt szakaszon közel az $E_{i}$ ponthoz minden $i=1,2,3$ esetén, ahol $\{j, k\}=\{1,2,3\} \backslash\{i\}$, és jelölje rendre az $E_{2} X_{3}, E_{3} X_{1}$ és $E_{1} X_{2}$ egyeneseket $\ell_{1}^{\prime}, \ell_{2}^{\prime}$ és $\ell_{3}^{\prime}$.

A $V_{1}=\ell_{2}^{\prime} \cap \ell_{3}^{\prime}, V_{2}=\ell_{3}^{\prime} \cap \ell_{1}^{\prime}$, és $V_{3}=\ell_{1}^{\prime} \cap \ell_{2}^{\prime}$ metszéspontok által alkotott nyílt szakaszok legyenek $\sigma_{1}^{\prime}=\overline{V_{2} V_{3}}, \sigma_{2}^{\prime}=\overline{V_{3} V_{1}}$ és $\sigma_{3}^{\prime}=\overline{V_{1} V_{2}}$.

Vegyük továbbá az $X_{1}^{t}=t_{1} \cap \ell_{3}^{\prime}, X_{2}^{t}=t_{2} \cap \ell_{1}^{\prime}, X_{3}^{t}=t_{3} \cap \ell_{2}^{\prime}$ és az $X_{1}^{\mathcal{H}}=$ $\partial \mathcal{H} \cap\left(\ell_{2}^{\prime} \backslash\left\{E_{3}\right\}\right), X_{2}^{\mathcal{H}}=\partial \mathcal{H} \cap\left(\ell_{3}^{\prime} \backslash\left\{E_{1}\right\}\right), X_{3}^{\mathcal{H}}=\partial \mathcal{H} \cap\left(\ell_{1}^{\prime} \backslash\left\{E_{2}\right\}\right)$ metszéspontokat is az érintőkön, illetve a $\partial \mathcal{H}$ görbén. Ezek a metszéspontok létrejönnek, amennyiben az $X_{i}$ pontokat elegendôen közel választjuk ki az $E_{i}(i=1,2,3)$ pontokhoz.

Végezetül legyen az $X_{2} E_{1} E_{2} \varangle, X_{3} E_{2} E_{3} \varangle, X_{1} E_{3} E_{1} \varangle$ szögek nagysága rendre $\xi_{1}, \xi_{2}, \xi_{3}$, míg az $X_{1}^{t} E_{1} E_{2} \varangle, X_{2}^{t} E_{2} E_{3} \varangle, X_{3}^{t} E_{3} E_{1} \varangle$ szögeké pedig rendre $\alpha_{1}, \alpha_{2}, \alpha_{3}$, és az $E_{3} E_{1} E_{2} \varangle, E_{1} E_{2} E_{3} \varangle, E_{2} E_{3} E_{1} \varangle$ szögeké rendre $\beta_{1}, \beta_{2}, \beta_{3}$.

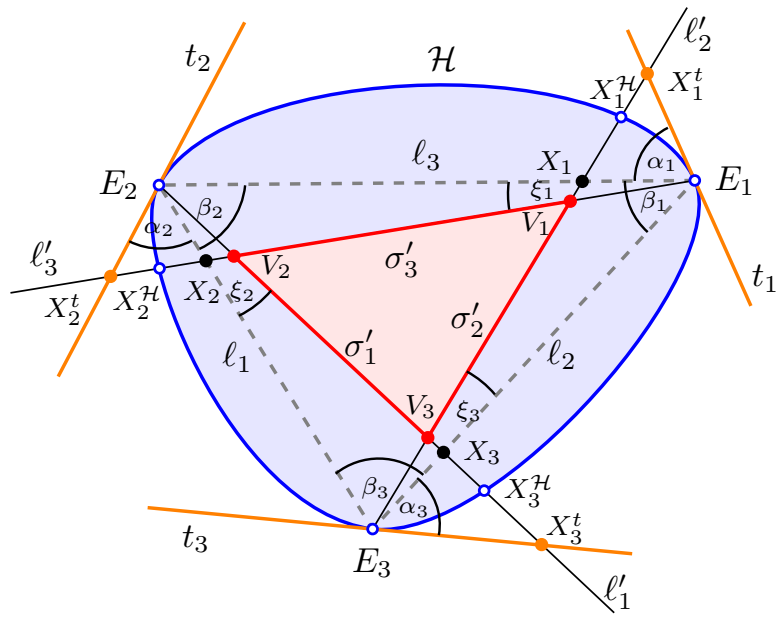

3.7. Ábra. Kibôvített 3.4. Konfiguráció

3.7. Tétel. [KKh, Theorem 4.4] Tekintsünk egy 3.6-konfigurációt. Minden $i=1,2,3$ esetén jelölje $B_{i}$ a $\sigma_{i}$ szakasz euklideszi felezôpontját, és $B_{i}^{\mathcal{H}}$ a nyílt $\sigma_{i}^{\prime}$ szakasz $\mathcal{H}$ felezốpontját. $A z f_{1}, f_{2}, f_{3}$ egyenesek akkor és csak akkor tartoznak egy nyalábhoz, ha az $X_{1}, X_{2}$ és $X_{3}$ pontok választhatók úgy bármely $\varepsilon, \delta>0$ esetén, hogy

$$
\begin{array}{r}
\left|B_{1}^{\mathcal{H}}-B_{1}\right|+\left|B_{2}^{\mathcal{H}}-B_{2}\right|+\left|B_{3}^{\mathcal{H}}-B_{3}\right|<\varepsilon, \\
\left|X_{1}-E_{1}\right|+\left|X_{2}-E_{2}\right|+\left|X_{3}-E_{3}\right|<\delta .
\end{array}
$$


Bizonyítás. Mivel $d_{\mathcal{H}}\left(V_{j}, B_{i}^{\mathcal{H}}\right)=d_{\mathcal{H}}\left(B_{i}^{\mathcal{H}}, V_{k}\right)$, ahol $\{i, j, k\}=\{1,2,3\}$, a (2.2) összefüggésből $\left(E_{j}, X_{k}^{\mathcal{H}} ; V_{j}, B_{i}^{\mathcal{H}}\right)=\left(E_{j}, X_{k}^{\mathcal{H}} ; B_{i}^{\mathcal{H}}, V_{k}\right)$ következik, így

$$
\begin{aligned}
1 & =\frac{\left(E_{j}, X_{k}^{\mathcal{H}} ; V_{j}, B_{i}^{\mathcal{H}}\right)}{\left(E_{j}, X_{k}^{\mathcal{H}} ; B_{i}^{\mathcal{H}}, V_{k}\right)}=\frac{\left(E_{j}, X_{k}^{\mathcal{H}}, V_{j}\right) /\left(E_{j}, X_{k}^{\mathcal{H}}, B_{i}^{\mathcal{H}}\right)}{\left(E_{j}, X_{k}^{\mathcal{H}} ; B_{i}^{\mathcal{H}}\right) /\left(E_{j}, X_{k}^{\mathcal{H}}, V_{k}\right)} \\
& =\frac{\left(E_{j}, X_{k}^{\mathcal{H}}, V_{k}\right)\left(E_{j}, X_{k}^{\mathcal{H}}, V_{j}\right)}{\left(E_{j}, X_{k}^{\mathcal{H}} ; B_{i}^{\mathcal{H}}\right)^{2}}=\frac{\left|E_{j}-V_{k}\right|\left|E_{j}-V_{j}\right|}{\left|X_{k}^{\mathcal{H}}-V_{k}\right|\left|X_{k}^{\mathcal{H}}-V_{j}\right|} \frac{1}{\left(E_{j}, X_{k}^{\mathcal{H}} ; B_{i}^{\mathcal{H}}\right)^{2}} .
\end{aligned}
$$

Ettől kezdve feltételezzük, hogy $\xi_{i} \rightarrow 0$ mindegyik $i=1,2,3$ értékre. Ekkor $X_{k}^{\mathcal{H}} \rightarrow$ $E_{k}$, az $\overline{E_{j} X_{k}^{\mathcal{H}}}$ szakasz affin felezópontja a $B_{i}$ ponthoz konvergál, és ezért $B_{i}^{\mathcal{H}} \rightarrow B_{i}$ akkor és csak akkor, ha $\left(E_{j}, X_{k}^{\mathcal{H}} ; B_{i}^{\mathcal{H}}\right) \rightarrow 1$. Mivel igaz, hogy $\frac{\left|E_{j}-V_{k}\right|}{\left|X_{k}^{\mathcal{H}}-V_{j}\right|} \rightarrow 1$, a (3.7) összefüggés szerint teljesül a

$$
\left(E_{j}, X_{k}^{\mathcal{H}} ; B_{i}^{\mathcal{H}}\right)^{2} \sim \frac{\left|E_{j}-V_{j}\right|}{\left|X_{k}^{\mathcal{H}}-V_{k}\right|}
$$

aszimptotikus egyenlôség, amely az elôzố következtetés szerint azt jelenti, hogy

$$
B_{i}^{\mathcal{H}} \rightarrow B_{i} \text { akkor és csak akkor, ha }\left|E_{j}-V_{j}\right| \sim\left|X_{k}^{\mathcal{H}}-V_{k}\right| .
$$

A szinusztétel felhasználásával kapjuk a következô aszimptotikus egyenlőségeket:

$$
\begin{aligned}
& \frac{\left|X_{k}^{\mathcal{H}}-V_{k}\right|}{\left|E_{j}-V_{j}\right|} \\
& =\frac{\left|X_{k}^{t}-E_{j}\right|-\left|V_{k}-E_{j}\right|-\left|X_{k}^{\mathcal{H}}-X_{k}^{t}\right|}{\left|E_{i}-E_{j}\right| \sin \xi_{i} / \sin \left(\beta_{j}-\xi_{j}+\xi_{i}\right)} \\
& =\frac{\frac{\left|E_{j}-E_{k}\right|}{\sin \left(\beta_{k}+\alpha_{k}+\xi_{j}\right)} \sin \left(\beta_{k}+\alpha_{k}\right)-\frac{\left|E_{j}-E_{k}\right|}{\sin \left(\beta_{k}-\xi_{k}+\xi_{j}\right)} \sin \left(\beta_{k}-\xi_{k}\right)-\left|X_{k}^{\mathcal{H}}-X_{k}^{t}\right|}{\frac{\left|E_{i}-E_{j}\right|}{\sin \left(\beta_{j}-\xi_{j}+\xi_{i}\right)} \sin \xi_{i}} \\
& =\frac{\sin \left(\beta_{j}-\xi_{j}+\xi_{i}\right)}{\sin \xi_{i}} \frac{\left|E_{j}-E_{k}\right|}{\left|E_{i}-E_{j}\right|} \times \\
& \times\left(\frac{\sin \left(\beta_{k}+\alpha_{k}\right)}{\sin \left(\beta_{k}+\alpha_{k}+\xi_{j}\right)}-\frac{\sin \left(\beta_{k}-\xi_{k}\right)}{\sin \left(\beta_{k}-\xi_{k}+\xi_{j}\right)}-\frac{\left|X_{k}^{\mathcal{H}}-X_{k}^{t}\right|}{\left|E_{j}-E_{k}\right|}\right) \\
& =\frac{\sin \left(\beta_{j}-\xi_{j}+\xi_{i}\right)}{\sin \xi_{i}} \frac{\left|\sigma_{i}\right|}{\left|\sigma_{k}\right|} \times \\
& \times\left(\frac{\operatorname{tg}\left(\beta_{k}+\alpha_{k}\right)}{\sin \xi_{j}+\cos \xi_{j} \operatorname{tg}\left(\beta_{k}+\alpha_{k}\right)}-\frac{\operatorname{tg}\left(\beta_{k}-\xi_{k}\right)}{\sin \xi_{j}+\cos \xi_{j} \operatorname{tg}\left(\beta_{k}-\xi_{k}\right)}-\frac{\left|X_{k}^{\mathcal{H}}-X_{k}^{t}\right|}{\left|E_{j}-E_{k}\right|}\right) \\
& =\frac{\sin \left(\beta_{j}-\xi_{j}+\xi_{i}\right)}{\sin \xi_{i}} \frac{\left|\sigma_{i}\right|}{\left|\sigma_{k}\right|} \times \\
& \times\left(\frac{\sin \xi_{j}\left(\operatorname{tg}\left(\beta_{k}+\alpha_{k}\right)-\operatorname{tg}\left(\beta_{k}-\xi_{k}\right)\right)}{\left(\sin \xi_{j}+\cos \xi_{j} \operatorname{tg}\left(\beta_{k}+\alpha_{k}\right)\right)\left(\sin \xi_{j}+\cos \xi_{j} \operatorname{tg}\left(\beta_{k}-\xi_{k}\right)\right)}-\frac{\left|X_{k}^{\mathcal{H}}-X_{k}^{t}\right|}{\left|E_{j}-E_{k}\right|}\right)
\end{aligned}
$$




$$
\begin{aligned}
= & \frac{\sin \xi_{j}}{\sin \xi_{i}} \frac{\left|\sigma_{i}\right|}{\left|\sigma_{k}\right|} \times \\
& \times\left(\frac{\sin \left(\beta_{j}-\xi_{j}+\xi_{i}\right)\left(\operatorname{tg}\left(\beta_{k}+\alpha_{k}\right)-\operatorname{tg}\left(\beta_{k}-\xi_{k}\right)\right)}{\left(\sin \xi_{j}+\cos \xi_{j} \operatorname{tg}\left(\beta_{k}+\alpha_{k}\right)\right)\left(\sin \xi_{j}+\cos \xi_{j} \operatorname{tg}\left(\beta_{k}-\xi_{k}\right)\right)}-\right. \\
& \left.\quad-\frac{\sin \left(\beta_{j}-\xi_{j}+\xi_{i}\right)\left|X_{k}^{\mathcal{H}}-X_{k}^{t}\right|}{\left|E_{j}-E_{k}\right| \sin \xi_{j}}\right) \\
\sim & \frac{\sin \xi_{j}}{\sin \xi_{i}} \frac{\left|\sigma_{i}\right|}{\left|\sigma_{k}\right|} \frac{\sin \beta_{j}\left(\operatorname{tg}\left(\beta_{k}+\alpha_{k}\right)-\operatorname{tg} \beta_{k}\right)}{\operatorname{tg}\left(\beta_{k}+\alpha_{k}\right) \operatorname{tg} \beta_{k}}=\frac{\sin \xi_{j}}{\sin \xi_{i}} \frac{\left|\sigma_{i}\right|}{\left|\sigma_{k}\right|} \frac{\sin \beta_{j} \sin \alpha_{k}}{\sin \left(\beta_{k}+\alpha_{k}\right) \sin \beta_{k}} .
\end{aligned}
$$

Ha ezt behelyettesítjük a (3.8) összefüggésbe, a követező feltételekhez jutunk:

$$
\begin{aligned}
B_{1}^{\mathcal{H}} \rightarrow B_{i} & \Longleftrightarrow \frac{\sin \xi_{1}}{\sin \xi_{2}} \sim \frac{\left|\sigma_{1}\right|}{\left|\sigma_{3}\right|} \frac{\sin \beta_{2} \sin \alpha_{3}}{\sin \left(\beta_{3}+\alpha_{3}\right) \sin \beta_{3}}, \\
B_{2}^{\mathcal{H}} \rightarrow B_{2} & \Longleftrightarrow \frac{\sin \xi_{2}}{\sin \xi_{3}} \sim \frac{\left|\sigma_{2}\right|}{\left|\sigma_{1}\right|} \frac{\sin \beta_{3} \sin \alpha_{1}}{\sin \left(\beta_{1}+\alpha_{1}\right) \sin \beta_{1}}, \\
B_{3}^{\mathcal{H}} \rightarrow B_{3} & \Longleftrightarrow \frac{\sin \xi_{3}}{\sin \xi_{1}} \sim \frac{\left|\sigma_{3}\right|}{\left|\sigma_{2}\right|} \frac{\sin \beta_{1} \sin \alpha_{2}}{\sin \left(\beta_{2}+\alpha_{2}\right) \sin \beta_{2}} .
\end{aligned}
$$

Minthogy választhatunk úgy egyébként tetszóleges $\xi_{2} \rightarrow 0, \xi_{1} \rightarrow 0$ és $\xi_{3} \rightarrow 0$ szögeket, hogy ezen aszimptotikus egyenlőségek közül az elsố kettô teljesüljön, és ekkor a harmadik teljesülése pontosan a szorzatuktól szorzatuktól függ. Ilyen szögek $\xi_{1}, \xi_{2}, \xi_{3}$ eszerint akkor és csak akkor választhatók, ha

$$
\sin \alpha_{1} \sin \alpha_{2} \sin \alpha_{3}=\sin \left(\beta_{1}+\alpha_{1}\right) \sin \left(\beta_{2}+\alpha_{2}\right) \sin \left(\beta_{3}+\alpha_{3}\right) .
$$

Jelölje az $f_{1} \ell_{2} \varangle, f_{2} \ell_{3} \varangle, f_{3} \ell_{1} \varangle$ szögek nagyságát rendre $\psi_{1}, \psi_{2}, \psi_{3}$, és a $f_{1} \ell_{3} \varangle, f_{2} \ell_{1} \varangle$, $f_{3} \ell_{2} \varangle$ szögekét rendre $\phi_{1}, \phi_{2}, \phi_{3}$. Nyilván $\psi_{i}+\phi_{i}=\beta_{i}$ minden $i=1,2,3$ számra (lásd a 3.8. Ábrát).

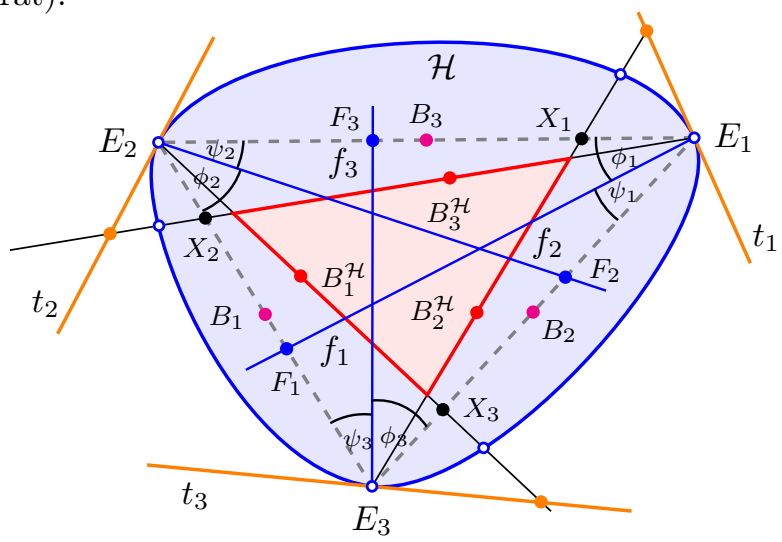

3.8. Ábra. Konstrukció a felezőpontokkal 


\section{Kozma J.}

Vegyük észre, hogy

$$
\begin{aligned}
& -1=\left(\ell_{3}, \ell_{2} ; t_{1}, f_{1}\right)=\frac{-\sin \alpha_{1} / \sin \left(\beta_{1}+\alpha_{1}\right)}{\sin \phi_{1} / \sin \psi_{1}}, \\
& -1=\left(\ell_{1}, \ell_{3} ; t_{2}, f_{2}\right)=\frac{-\sin \alpha_{2} / \sin \left(\beta_{2}+\alpha_{2}\right)}{\sin \phi_{2} / \sin \psi_{2}}, \\
& -1=\left(\ell_{2}, \ell_{1} ; t_{3}, f_{3}\right)=\frac{-\sin \alpha_{3} / \sin \left(\beta_{3}+\alpha_{3}\right)}{\sin \phi_{3} / \sin \psi_{3}},
\end{aligned}
$$

így a (3.9) egyenlőség ekvivalens az

$$
1=\frac{\sin \phi_{1}}{\sin \psi_{1}} \frac{\sin \phi_{2}}{\sin \psi_{2}} \frac{\sin \phi_{3}}{\sin \psi_{3}}
$$

egyenlőséggel. Legyen $F_{i}:=f_{i} \cap \sigma_{i}$ minden $i=1,2,3$ számra. Ekkor a szinusztétel alapján kapjuk, hogy

$\left(E_{1}, E_{2} ; F_{3}\right)=\frac{\left|\sigma_{2}\right|}{\left|\sigma_{1}\right|} \frac{\sin \phi_{3}}{\sin \psi_{3}},\left(E_{2}, E_{3} ; F_{1}\right)=\frac{\left|\sigma_{3}\right|}{\left|\sigma_{2}\right|} \frac{\sin \phi_{1}}{\sin \psi_{1}}$, és $\left(E_{3}, E_{1} ; F_{2}\right)=\frac{\left|\sigma_{1}\right|}{\left|\sigma_{3}\right|} \frac{\sin \phi_{2}}{\sin \psi_{2}}$.

A Ceva-tétel szerint ezeknek az arányoknak a szorzata akkor és csak akkor egyenlő 1gyel, ha az $f_{1}, f_{2}$ és $f_{3}$ egyenesek egy nyalábhoz tartoznak. Ez bizonyítja a tételt. 


\section{A hiperbolikus geometria karakterizációi a Hilbert-geometriák között}

\subsection{Karakterizáció Ceva- és Menelaosz-tulajdonsággal}

Hilbert-geometriákban általában egyik tétel sem érvényes, sốt egy ezeknél sokkal gyengébb feltétel is karakterizálja a hiperbolikus geometriát.

4.1. Tétel. ([KKc, Theorem 3.1]) Egy Hilbert-geometriában akkor és csak akkor létezik minden $A B C \triangle$ trigonhoz olyan $\left(C^{\prime}, A^{\prime}, B^{\prime}\right)$ Ceva-triplet, hogy az $\left(\left\langle A, B ; C^{\prime}\right\rangle,\left\langle B, C ; A^{\prime}\right\rangle,\left\langle C, A ; B^{\prime}\right\rangle\right)$ számhármas Ceva típusú, ha ez a geometria hiperbolikus.

Bizonyítás. Vizsgáljuk a $\left(\mathcal{H}, d_{\mathcal{H}}\right)$ Hilbert-geometriát! Ha $\mathcal{H}$ egy ellipszoid, akkor a 2.15. Tétel szerint teljesül a Ceva tétel, ezért elég a fordított állítást igazolni.

Tekintettel a 2.7. Lemmára elegendô a síkban dolgoznunk.

Indirekt módon bizonyítunk. Tételezzük fel, hogy $\partial \mathcal{H}$ nem ellipszis, de minden háromszögben igaz Ceva tétele.

Ekkor a 2.9. Lemma szerint van egy olyan $\mathcal{E} \supseteq \mathcal{H}$ ellipszis, hogy a $\partial \mathcal{E} \cap \partial \mathcal{H}$ halmaznak létezik legalább hat különböző $P_{i}(i=1, \ldots, 6)$ pontja, és $\mathcal{E} \backslash \mathcal{H}$ tartalmaz belsố pontot. Válasszunk ebból egy $P_{0} \in \mathcal{E} \backslash \mathcal{H}$ pontot úgy, hogy ennek egy $\mathcal{U}$ környezete is a $\mathcal{E} \backslash \mathcal{H}$ halmaz része legyen.

A $P_{0} P_{i}(i=1,2,3,4,5)$ egyenesek nyilvánvalóan páronként különbözők, így közülük pontosan egy olyan van, amely úgy választja el a rá nem esố maradék négy pontot, hogy pontosan kettő-kettô esik a két különböző oldalára. Tegyük fel, hogy az indexek választásával ez a szeparáló egyenes $P_{0} P_{3}$, a $P_{1}$ és $P_{2}$ pontok vannak az egyik, a $P_{4}$ és $P_{5}$ pontok a másik oldalán; továbbá a $\overline{P_{1} P_{4}}$ szakasz az $\overline{P_{2} P_{5}}$ szakaszt egy $A \in \mathcal{E} \cap \mathcal{H}$ pontban metszi. Ha $A \in \overline{P_{0} P_{3}}$, akkor mozdítsuk el a $P_{0}$ pontot egy kicsit úgy, hogy maradjon az $\mathcal{U}$ környezetben, de a $P_{0} P_{3}$ egyenes szeparálja egymástól a $\overline{P_{1} P_{2}}$ és $\overline{P_{4} P_{5}}$ szakaszt. Így már $A \notin \overline{P_{0} P_{3}}$ (lásd 4.1. Ábra jobb oldalán).
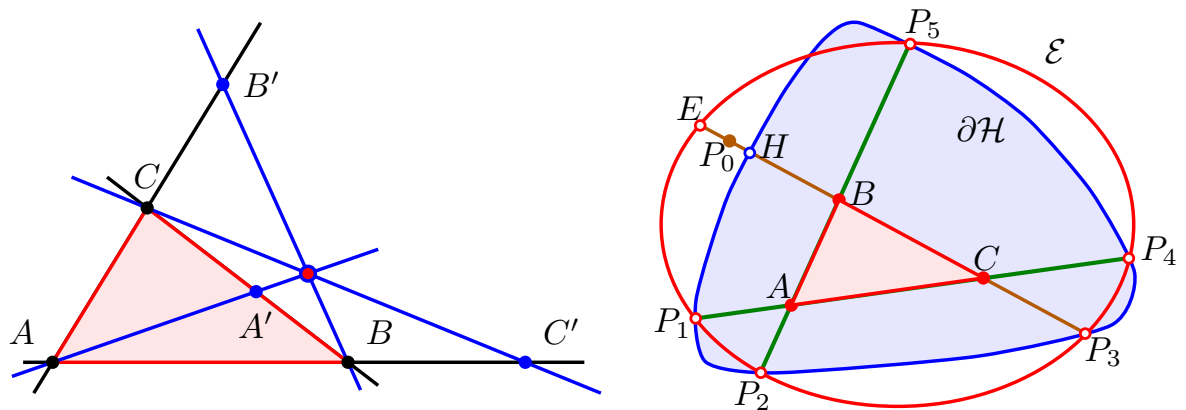

4.1. Ábra. Ceva-konfiguráció és egy háromszög az ellenpéldához 
Legyen $B=\overline{P_{0} P_{3}} \cap \overline{P_{1} P_{4}}$, és $C=\overline{P_{0} P_{3}} \cap \overline{P_{2} P_{5}}$. Ekkor $A B C \triangle$ egy trigon.

Azonnal észrevehetjük, hogy a nyílt $\overline{P_{1} P_{4}}$ és $\overline{P_{2} P_{5}}$ szakaszok egyszerre egyenesei a $\left(\mathcal{H}, d_{\mathcal{H}}\right)$ Hilbert-geometriának, valamint az $\left(\mathcal{E}, d_{\mathcal{E}}\right)$ hiperbolikus geometriának, ugyanis végpontjaik az egyes geometriákat meghatározó mindkét konvex halmaznak a határán vannak (metszéspontok).

Továbbá a nyílt $\overline{P_{3} E}=\mathcal{H} \cap P_{3} P_{0}$ szakasz az $\left(\mathcal{E}, d_{\mathcal{E}}\right)$ hiperbolikus geometriának egyenese, míg a $\overline{P_{3} H}=\mathcal{H} \cap \overline{P_{3} P_{0}}$ nyílt szakasz a $\left(\mathcal{H}, d_{\mathcal{H}}\right)$ Hilbert-geometriának egyenese, és ráadásul az is teljesül, hogy $\overline{P_{3} H} \subsetneq \overline{P_{3} E}$.

A tétel feltétele szerint létezik az $A B C \triangle$ háromszögnek egy olyan $\left(C^{\prime}, A^{\prime}, B^{\prime}\right)$ Ceva-tripletje, amelyre

az $\left(\left\langle A, B ; C^{\prime}\right\rangle_{\mathcal{H}},\left\langle B, C ; A^{\prime}\right\rangle_{\mathcal{H}},\left\langle C, A ; B^{\prime}\right\rangle_{\mathcal{H}}\right)$ számhármas Ceva típusú.

A két geometria közös egyenesei esetében a hiperbolikus osztóviszonyok megegyeznek, míg a harmadik egyenespár esetében $\left\langle B, C ; A^{\prime}\right\rangle_{\mathcal{H}} \neq\left\langle B, C ; A^{\prime}\right\rangle_{\mathcal{E}}$ a 3.1. Lemma következtében. Így a (4.1) összefüggés azt eredményezi, hogy

a $\left(\left\langle A, B ; C^{\prime}\right\rangle_{\mathcal{E}},\left\langle B, C ; A^{\prime}\right\rangle_{\mathcal{E}},\left\langle C, A ; B^{\prime}\right\rangle_{\mathcal{E}}\right)$ számhármas nem Ceva típusú.

Ez viszont ellentmondásban van a 2.15. Hiperbolikus Ceva-tétellel, amely ellentmondás mutatja a tétel igazságát.

4.2. Tétel. ([KKc, Theorem 3.2]) Egy $\left(\mathcal{H}, d_{\mathcal{H}}\right)$ Hilbert-geometriában akkor és csak akkor létezik minden $A B C \triangle$ trigonhoz olyan $\left(C^{\prime}, A^{\prime}, B^{\prime}\right)$ Menelaosz-triplet, amelyre az $\left(\left\langle A, B ; C^{\prime}\right\rangle,\left\langle B, C ; A^{\prime}\right\rangle,\left\langle C, A ; B^{\prime}\right\rangle\right)$ számhármas Menelaosz típusú, ha $\left(\mathcal{H}, d_{\mathcal{H}}\right)$ hiperbolikus.

Bizonyítás. Ha $\mathcal{H}$ egy ellipszoid, akkor a 2.14 tétel szerint Menelaosz tétele teljesül. Figyelemmel a 2.7. Lemmára, ezúttal is elegendô a síkban dolgoznunk, és erre tekintettel a továbbiakban $\mathcal{H}$ egy síkbeli nyílt, szigorúan konvex tartományt jelöl.

Feltéve, hogy minden tripletre teljesülnek a tétel feltételei, és hogy $\mathcal{H}$ nem ellipszis, ellentmondáshoz fogunk jutni.

A 2.9. Lemma szerint van egy olyan $\mathcal{E}$ ellipszis, amely esetén a $\partial \mathcal{E} \cap \partial \mathcal{H}$ halmaznak létezik legalább hat különbözô $P_{i}(i=0,1, \ldots, 5)$ pontja, és $\mathcal{E} \backslash \mathcal{H}$ tartalmaz egy belsố pontot.

Válasszunk egy $P_{0} \in \mathcal{E} \backslash \mathcal{H}$ pontot ebból a nem üres halmazból úgy, hogy e pontnak egy $\mathcal{U}$ környezete is a $\mathcal{E} \backslash \mathcal{H}$ halmaz része legyen.

Hasonlóan a Ceva-karakterizáció bizonyításához (lásd a 4.2. Ábrát), most is találhatunk olyan $P_{i}(i=0,1, \ldots, 6)$ pontokat, hogy

(i) a $P_{0} P_{i}(i=1, \ldots, 5)$ egyenesek páronként különbözók; 
(ii) a $P_{0} P_{3}$ egyenes elválasztja a $\overline{P_{1} P_{2}}$ és a $\overline{P_{4} P_{5}}$ szakaszt;

(iii) az $A=\overline{P_{1} P_{4}} \cap \overline{P_{2} P_{5}}$ pont a $\mathcal{E} \cap \mathcal{H}$ metszetben van;

(iv) az $A$ pont nincsen az $\overline{P_{0} P_{3}}$ egyenesen.
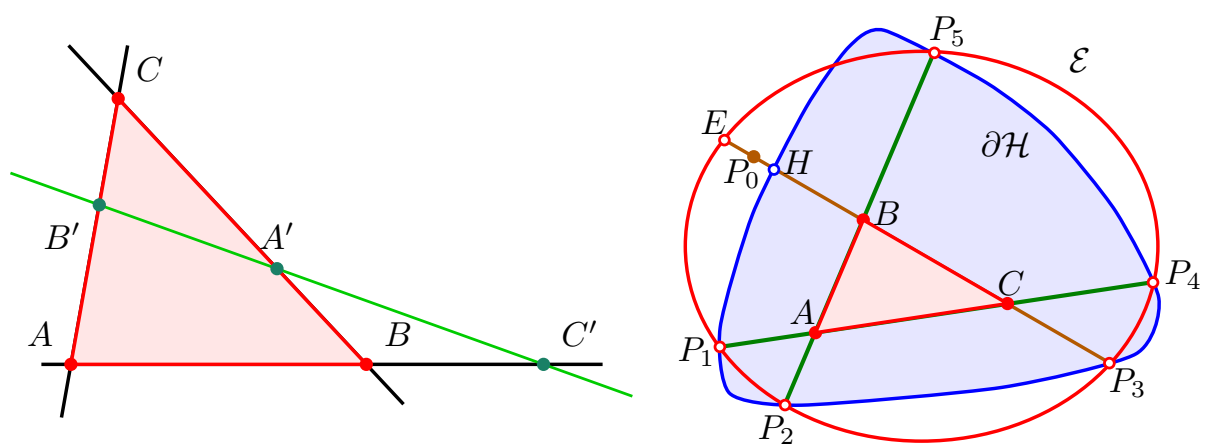

4.2. Ábra. Menelaosz-konfiguráció és egy háromszög az ellenpéldához

Az elválasztások miatt létrejönnek a $B=\overline{P_{0} P_{3}} \cap \overline{P_{1} P_{4}}$ és $C=\overline{P_{0} P_{3}} \cap \overline{P_{2} P_{5}}$ metszéspontok, és e pontokkal az $A B C \triangle$ egy trigon.

A konvex $\mathcal{H}$ és $\mathcal{E}$ tartományok határának metszéspontjait összekötő szakaszok egyenesei a $\mathcal{H}$-val adott Hilbert-geometriának és az $\mathcal{E}$-vel adott hiperbolikus geometriának is. Ilyen közös egyenesek a nyílt $\overline{P_{1} P_{4}}$ és $\overline{P_{2} P_{5}}$ szakaszok.

Megállapíthatjuk továbbá, hogy a nyílt $\overline{P_{3} E}=\mathcal{H} \cap P_{3} P_{0}$ szakasz az $\left(\mathcal{E}, d_{\mathcal{E}}\right)$

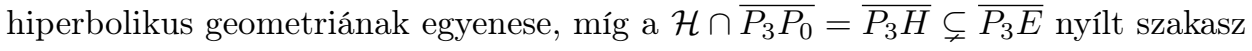
a $\left(\mathcal{H}, d_{\mathcal{H}}\right)$ Hilbert-geometriának egyenese.

A tétel feltétele szerint létezik az $A B C \triangle$ trigonnak egy olyan $\left(C^{\prime}, A^{\prime}, B^{\prime}\right)$ Menelaosz-tripletje, amelyre az $\left(\left\langle A, B ; C^{\prime}\right\rangle_{\mathcal{H}},\left\langle B, C ; A^{\prime}\right\rangle_{\mathcal{H}},\left\langle C, A ; B^{\prime}\right\rangle_{\mathcal{H}}\right)$ számhármas Menelaosz típusú.

A két geometria közös egyenesei esetében a hiperbolikus osztóviszonyok megegyeznek, míg a harmadik egyenespár esetében a 3.1. Lemma következtében $\left\langle B, C ; A^{\prime}\right\rangle_{\mathcal{H}} \neq\left\langle B, C ; A^{\prime}\right\rangle_{\mathcal{E}}$, így

$$
\left\langle A, B ; C^{\prime}\right\rangle_{\mathcal{H}}\left\langle C, A ; B^{\prime}\right\rangle_{\mathcal{H}}\left\langle B, C ; A^{\prime}\right\rangle_{\mathcal{H}} \neq\left\langle A, B ; C^{\prime}\right\rangle_{\mathcal{E}}\left\langle C, A ; B^{\prime}\right\rangle_{\mathcal{E}}\left\langle B, C ; A^{\prime}\right\rangle_{\mathcal{E}}=-1 .
$$

Ez ellentmondás, hiszen a bal oldali számok Menelaosz típusúak.

Érdemes megjegyezni, hogy hasonló probléma a Minkowski-geometriákban fel sem vetődik, hiszen a pontok metrikus osztóviszonya megegyezik az affin osztóviszonnyal, és ezért a Ceva-tétel és a Menelaosz-tétel pontosan ugyanúgy teljesül, mint az affin geometriában. 
Kozma J.

\subsection{Karakterizáció biszektorális centrummal}

Az euklideszi geometriában érvényes tétel szerint az oldalfelezô merólegesek egy pontra, a körülírt kör középpontjára illeszkednek. Ugyanez a hiperbolikus geometriában csak annyiban igaz, hogy az oldalfelezô merólegesek nyalábot alkotnak (2.16. Tétel).

Felvetődik a kérdés, hogy a Hilbert-geometriában milyen feltétellel teljesül egy ilyen állítás, és ha teljesül, akkor mit mondhatunk a geometriáról? A választ a $\mathcal{H}$-merólegességre adjuk meg.

4.3. Tétel. ([KKh, Theorem 5.1]) Egy Hilbert-geometriában akkor és csak akkor létezik minden háromszögnek biszektorális centruma, ha a geometria hiperbolikus.

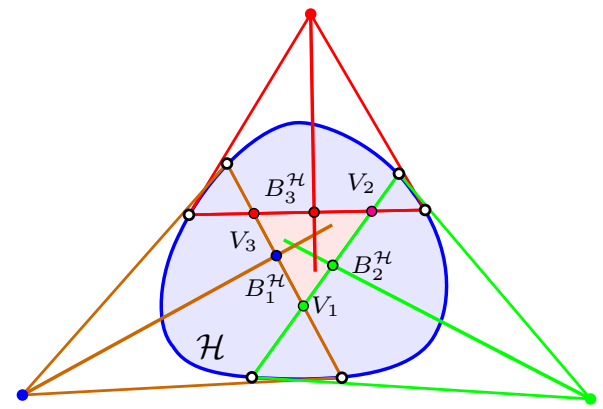

4.3. Ábra. Trigon oldalfelezô $\mathcal{H}$-merôlegesei Hilbert-geometriában

Bizonyítás. Vizsgáljuk a $\left(\mathcal{H}, d_{\mathcal{H}}\right)$ Hilbert-geometriát! Ha $\mathcal{H}$ egy ellipszoid, akkor a 2.16. Tétel szerint teljesül a Ceva tétel, ezért elég a fordított állítást igazolni. A 2.7. Lemmára tekintettel elegendő a síkban dogoznunk.

Indirekt bizonyítást végezve tegyük fel, hogy $\mathcal{H}$ nem ellipszis.

A 2.10. Lemma (1) része szerint van egy minimális területû $\mathcal{E}$ ellipszis a $\mathcal{H}$ köré írva, a $\partial \mathcal{H} \cap \partial \mathcal{E}$-ban lévô legalább három különbözô $E_{1}, E_{2}, E_{3}$ érintkezési ponttal azzal a tulajdonsággal, hogy a zárt $E_{1} E_{2} E_{3} \triangle$ trigon tartalmazza az origót.

Tekintsük a 2.10. Lemma (4) részében leírt konfigurációt.

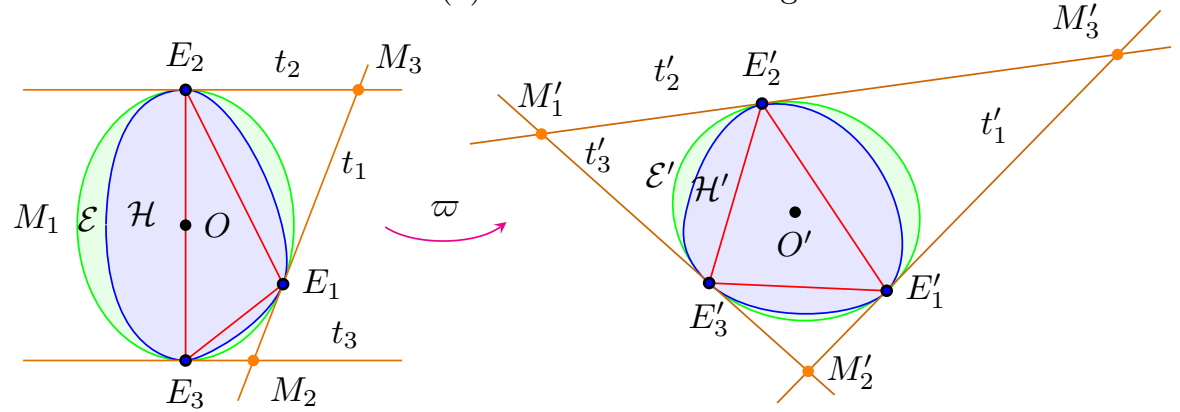

4.4. Ábra. A $\varpi$ projektivitás hatása, ha az $O \in \overline{E_{2} E_{3}}$ 
Válasszunk egy $\mathcal{S}^{\prime}$ síkot úgy, hogy az $\ell=\mathcal{S} \cap \mathcal{S}^{\prime}$ egyenes messe a $t_{2}$ és $t_{3}$ érintố egyeneseket, továbbá az $\mathcal{S}^{\prime}$ egyik $\Sigma$ féltere tartalmazza az $M_{2}, M_{3}$ pontokat és az $\mathcal{E}$ ellipszist. Válasszunk most egy $P$ pontot $\mathcal{S}^{\prime} \cup \mathcal{S}$-en kívül a $\Sigma$ féltérben. Legyen $\varpi$ az $\mathcal{S}$ síknak az $\mathcal{S}^{\prime}$ síkba való perspektív vetítése a $P$ pontból. Ez a $\varpi$ vetítés a 2.10. Lemma (4) részében leírt $\mathcal{S}$ síkbeli konfigurációt az $\mathcal{S}^{\prime}$ síknak egy a 2.10. Lemma (3) részében leírt konfigurációjába viszi (lásd a 4.4. Ảbrát).

Eszerint, mivel a tétel állítása projektív jellegú, feltételezhetô, hogy olyan konfigurációval állunk szemben, amelyet a 2.10. Lemma (3) része ír le. Bôvítsük ezt a konfigurációt egy 3.6. Konfigurációra (lásd a 4.5. Ábrát) úgy, hogy

$$
\varepsilon=\left|X_{1}-E_{1}\right|+\left|X_{2}-E_{2}\right|+\left|X_{3}-E_{3}\right| .
$$

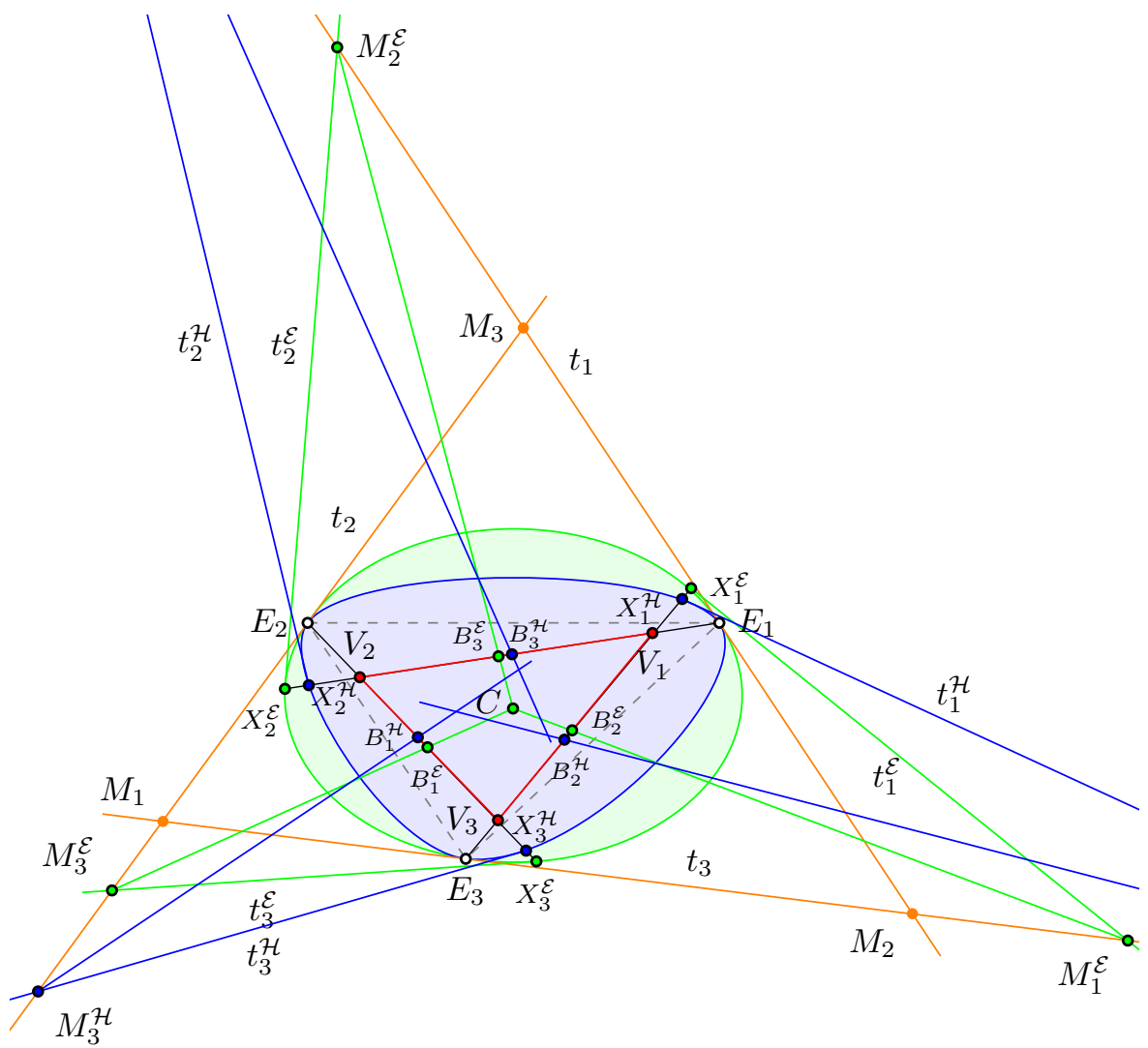

4.5. Ábra. Biszektorális középpontok konstrukciója $\mathcal{H}$ és $\mathcal{E}$ esetén

A 2.10. Lemma (5) része szerint az $M_{i} B_{i}(i=1,2,3)$ egyenesek találkoznak az $\mathcal{E}$ ellipszis $O$ centrumában, amely az $E_{1} E_{2} E_{3} \triangle$ belsejében van, és ezért az $\mathcal{E}$ 
ellipszis $O$ középpontja a $V_{1} V_{2} V_{3} \triangle$ trigonnak is a belsejében van, amennyiben az $\varepsilon$ érték elegendôen kicsi, amit mostantól fogva fel is teszünk.

A 3.1. Lemmának megfelelóen az $\ell_{1}^{\prime}, \ell_{2}^{\prime}, \ell_{3}^{\prime}$ egyenesek rendre az itt megadott sorrendben tartalmazzák az alábbi pontokat (lásd a 4.5. Ábrát):

$$
\begin{aligned}
& E_{2} \prec V_{2} \prec B_{1}^{\mathcal{H}} \prec B_{1}^{\mathcal{E}} \prec V_{3} \prec X_{3} \prec X_{3}^{\mathcal{H}} \prec X_{3}^{\mathcal{E}}, \\
& E_{3} \prec V_{3} \prec B_{2}^{\mathcal{H}} \prec B_{2}^{\mathcal{E}} \prec V_{1} \prec X_{1} \prec X_{1}^{\mathcal{H}} \prec X_{1}^{\mathcal{E}}, \\
& E_{1} \prec V_{1} \prec B_{3}^{\mathcal{H}} \prec B_{3}^{\mathcal{E}} \prec V_{2} \prec X_{2} \prec X_{2}^{\mathcal{H}} \prec X_{2}^{\mathcal{E}}
\end{aligned}
$$

Vegyük a $\mathcal{H}$, illetve $\mathcal{E}$ tartományok $t_{i}^{\mathcal{H}}$, illetve $t_{i}^{\mathcal{E}}$ érintó egyeneseit azok $X_{i}^{\mathcal{E}}$, illetve $X_{i}^{\mathcal{H}}$ pontjainál minden $i \in\{1,2,3\}$ értékre.

Legyen $M_{1}^{\mathcal{H}}=t_{3}^{\mathcal{H}} \cap t_{2}, M_{2}^{\mathcal{H}}=t_{1}^{\mathcal{H}} \cap t_{3}$, és $M_{3}^{\mathcal{H}}=t_{2}^{\mathcal{H}} \cap t_{1}$, továbbá $M_{1}^{\mathcal{E}}=t_{3}^{\mathcal{E}} \cap t_{2}$, $M_{2}^{\mathcal{E}}=t_{1}^{\mathcal{E}} \cap t_{3}$, és $M_{3}^{\mathcal{E}}=t_{2}^{\mathcal{E}} \cap t_{1}$ (lásd a 4.5 . Ábrát).

A 3.2. Lemma szerint a $t_{1}, t_{2}, t_{3}$ érintők rendre az itt megadott sorrendben tartalmazzák az

$$
\begin{gathered}
M_{2} \prec E_{1} \prec M_{3} \prec M_{3}^{\mathcal{E}} \prec M_{3}^{\mathcal{H}}, \quad M_{3} \prec E_{2} \prec M_{1} \prec M_{1}^{\mathcal{E}} \prec M_{1}^{\mathcal{H}}, \\
M_{1} \prec E_{3} \prec M_{2} \prec M_{2}^{\mathcal{E}} \prec M_{2}^{\mathcal{H}}
\end{gathered}
$$

pontokat (lásd a 4.5. Ábrát).

Figyelembe véve, hogy a $V_{1} V_{2} V_{3} \triangle$ trigon az Int $\mathcal{H} \cap$ Int $\mathcal{E}$ metszetben van, ha $\varepsilon \rightarrow 0$, akkor e háromszög tart az $E_{1} E_{2} E_{3} \triangle$ trigonhoz euklideszi értelemben, így a 3.2. Lemma azt eredményezi, hogy

$$
M_{i}^{\mathcal{H}} \rightarrow M_{i}, \quad \text { és } \quad M_{i}^{\mathcal{E}} \rightarrow M_{i} \quad \text { minden } i \in\{1,2,3\} \text { értékre. }
$$

Másrészt a 3.5. és a 3.7. Tétel azt eredményezi, hogy

$$
B_{i}^{\mathcal{E}} \rightarrow B_{i}, \quad \text { és } B_{i}^{\mathcal{H}} \rightarrow B_{i} \quad \text { minden } i \in\{1,2,3\} \text { értékre, }
$$

amint $\varepsilon \rightarrow 0$.

A (4.5) és (4.6) megállapítások szerint a $V_{1} V_{2} V_{3} \triangle$ trigon $C$ hiperbolikus biszektorális centruma konvergál az $\mathcal{E}$ ellipszis $O$ centrumához, amint $\varepsilon \rightarrow 0$, és ezért a $C$ biszektorális centrum a $V_{1} V_{2} V_{3} \triangle$ trigon belsejében van, ha $\varepsilon$ elegendôen kicsiny.

Tegyük fel, hogy a $V_{1} V_{2} V_{3} \triangle$ trigonnak szintén van egy $\mathcal{H}$-biszektorális középpontja (a $\mathcal{H}$ geometriában), legyen ez $C^{\prime}$. A (4.5) és a (4.6) összefüggések szerint a $\mathcal{H}$-biszektorális $C^{\prime}$ középpont a $\mathcal{E}$ ellipszis $O$ középpontjához is konvergál, amint $\varepsilon \rightarrow 0$, ezért $V_{1} V_{2} V_{3} \triangle$ trigon belsejében van, ha $\varepsilon$ elegendően kicsiny.

Tekintettel a (4.3) és (4.4) összefüggésekre, a $\overline{M_{i}^{\mathcal{H}} B_{i}^{\mathcal{H}}}$ és $\overline{M_{i}^{\mathcal{E}} B_{i}^{\mathcal{E}}}$ szakaszoknak minden $i \in\{1,2,3\}$ értékre van egy közös pontja, amely az $\ell$ egyenesnek ugyanazon az oldalán van, mint az $M_{i}$. 
Ebból következik, hogy $C^{\prime}$ az $M_{i}^{\mathcal{E}} B_{i}^{\mathcal{E}}$ egyeneseknek a bal oldali nyílt félsíkjában van (ahol az egyeneseket $M_{i}^{\mathcal{E}}$-tól $B_{i}^{\mathcal{E}}$ felé irányítjuk) minden $i \in\{1,2,3\}$ értékre.

Ez ellentmond annak a ténynek, hogy e három félsík metszete üres, ezért a $C^{\prime}$ létezésére vonatkozó feltevés nem tartható, és így a tételt bizonyítottuk.

\subsection{Karakterizáció ortocentrummal}

Az euklideszi geometriában érvényes tétel szerint a háromszögek magasságvonalai egy pontra, a magasságpontra illeszkednek. A hiperbolikus geometriában ezzel szemben csak annyit állíthatunk, hogy a magasságvonalak nyalábot alkotnak (2.17. Tétel).

Itt is felvetôdik a kérdés, hogy ez milyen Hilbert-geometriákban teljesül? A választ most is a $\mathcal{H}$-merólegességre adjuk meg.

4.4. Tétel. ([KKh, Theorem 5.2]) Ha egy Hilbert-geometriában minden trigonnak van ortocentruma, akkor az hiperbolikus geometria.

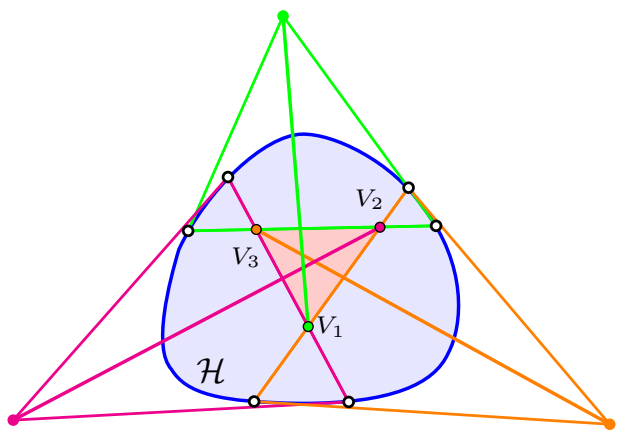

4.6. Ábra. Trigon magasságvonalainak egyenesei Hilbert-geometriában

Bizonyítás. Mivel trigonok oldalaira merôleges egyenesek illeszkedéséról van szó most is, akár az oldalfelezô merólegesek esetében, a 4.3. Tétel bizonyításának lépéseit követhetjük, csak ezúttal a felezőpontokra vonatkozó megfontolások nélkül.

A bizonyítást most is elegendô a síkban elvégezni, ahol most is tekintjük a $\left(\mathcal{H}, d_{\mathcal{H}}\right)$ tartománya köré írt minimális $\mathcal{E}$ ellipszist. Ezután vesszük az $E_{i}$ érintési pontok $(i=1,2,3)$ háromszögét, oldalain a csúcsokhoz közeli $X_{1}, X_{2}, X_{3}$ pontokkal, majd az általuk meghatározott $V_{1} V_{2} V_{3} \triangle$ trigont az érintési pontok háromszögének belsejében. Továbbá tekintjük e háromszög oldalegyeneseinek a $\partial \mathcal{H}$ és $\partial \mathcal{E}$ határgörbékkel vett $X_{i}^{\mathcal{H}}$, illetve $X_{i}^{\mathcal{E}}$ metszéspontjaiban vett $t_{i}^{\mathcal{H}}$, illetve $t_{i}^{\mathcal{E}}$ érintôknek a közös érintókkel vett $M_{i}^{\mathcal{H}}$, illetve $M_{i}^{\mathcal{E}}$ metszéspontjait (lásd a 4.7. Ábrát) minden $i=1,2,3$ értékre. 
Kozma J.

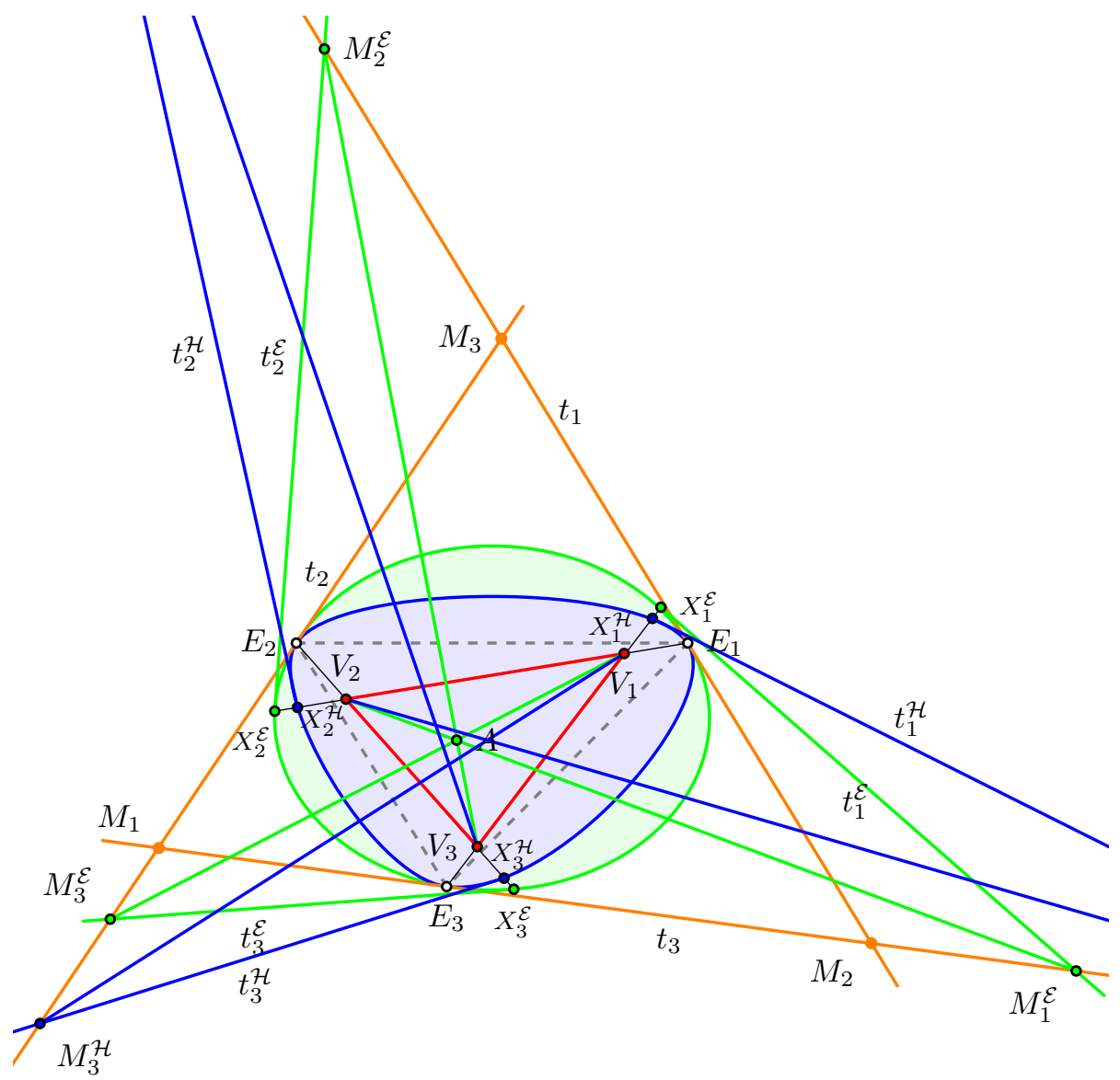

4.7. Ábra. Háromszög, melynek magasságai belső pontokban találkoznak

A (4.5) összefüggésnek megfelelően a $V_{1} V_{2} V_{3} \triangle$ trigon $V_{i} M_{i}^{\mathcal{E}}(i=1,2,3)$ hiperbolikus magasságvonalainak $A$ metszéspontja konvergál az $\mathcal{E}$ ellipszis $O$ középpontjához, amint $\varepsilon \rightarrow 0$, ahol $\varepsilon$ ezúttal is a (4.2) által adott. Így az $A$ pont az $V_{1} V_{2} V_{3} \triangle$ trigon belsejében van, ha $\varepsilon$ elegendően kicsiny.

Tegyük fel, hogy a $V_{1} V_{2} V_{3} \triangle$ trigon $V_{i} M_{i}^{\mathcal{H}}(i=1,2,3)$ magasságvonalai is metszik egymást egy közös $A^{\prime}$ pontban.

A (4.5) szerint az $A^{\prime}$ pont szintén konvergál az $\mathcal{E}$ ellipszis $O$ centrumához. Így ez a pont a $V_{1} V_{2} V_{3} \triangle$ trigon belsejében van, ha $\varepsilon$ elegendóen kicsiny.

A (4.4) összefüggéseket figyelembe véve $V_{i}=V_{i} M_{i}^{\mathcal{H}} \cap V_{i} M_{i}^{\mathcal{E}}$ minden $i \in$ $\{1,2,3\}$ értékre, és ezért $A^{\prime}$ a bal nyílt félsíkjában van mindegyik irányított $V_{i} M_{i}^{\mathcal{E}}$ egyenesnek, amelyeken $V_{i} \prec M_{i}^{\mathcal{E}}$ minden $i \in\{1,2,3\}$ értékre. 
Ez viszont ellentmond annak a ténynek, hogy ezeknek a félsíkoknak a metszete üres. Ezért az $A^{\prime}$ létezésére vonatkozó feltevést el kell vetnünk. Vagyis amennyiben $\mathcal{H}$ nem egyezik meg az $\mathcal{E}$ ellipszissel, akkor van olyan trigon, amelynek nincsen ortocentruma, ellentétben a tétel feltételével. Így a geometria valóban hiperbolikus.

Jegyezzük meg, hogy a $\mathcal{H}$-merőlegesség helyett a Birkhoff-merőlegességet (2.20. Definíció) használva nem jutottunk eredményre, és az irodalomban sem találtunk akár csak hasonló eredményt sem. 
Kozma J.

\section{Az euklideszi geometria karakterizációi a Minkowski-geometriák között}

A Hilbert-geometriáknál már megvizsgált Ceva- és Menelaosz-tulajdonság minden Minkowski-geometriában teljesül, hiszen a metrikus és affin osztóviszony megegyezik. Ellenben háromszögekkel kapcsolatos olyan nevezetes konfigurációk, illetve pontok, amelyek a merôlegességgel kapcsolatosak, már karakterisztikusak.

Mind a biszektorális centrum, mind az ortocentrum esetében bebizonyítjuk, hogy a korábban bevezetett bal-, illetve jobb-merôlegesség esetén létezésük karakterizálja az euklideszi geometriát a Minkowski-geometriák között. Míg Hilbert-esetben a Birkhoff-merólegességre nem tudtunk karakterizálást igazolni, addig Minkowskigeometriában a 2.12. Definíció szerinti bal-merôlegesség, illetve annak inverzeként bevezetett jobb-merôlegesség fogalmát alkalmazva is bebizonyíthatjuk a karakterizációt $[\mathrm{Km}]$.

$\mathrm{Az}$ indikátrix $\mathcal{I}$ határgörbéjérôl feltesszük a kétszeres differenciálhatóságot.

\subsection{Karakterizáció jobb-biszektorális és jobb-ortocentrummal}

Elôször a jobb-meróleges oldalfelezô egyenesek, majd a jobb-meróleges magasságvonalak egyeneseinek konkurenciáját vizsgáljuk meg.

A biszektorális centrum kérdésével kezdjük. A 2.12. Definíció után tett megállapításunk szerint egy trigon három (akár bal-, akár jobb-) oldalfelezô merôlegese közül bármely kettő metszi egymást. A vizsgálatnak tehát a páronkénti metszéspontok megegyezésére kell vonatkoznia.

5.1. Tétel. ([Km, Theorem 3.1]) Egy Minkowski-geometriában a jobb-meróleges oldalfelezók akkor és csak akkor konkurensek minden háromszögre, ha a geometria euklideszi.

Bizonyítás. Elegendôség. Euklideszi geometriában a jobb-merőleges oldalfelező egyenesek a közönséges oldalfelezố merőlegesek, ezért egy ponton mennek át.

Szükségesség. Mivel a későbbiekben hivatkozni fogunk ennek a bizonyításnak egyes részleteire, a fó lépéseket megszámozzuk.

(A1. LÉPÉS) A 2.7. Lemmára tekintettel elegendô azt megmutatni, hogy az indikátrix határának minden, az origón átmenô kétdimenziós síkkal való metszete egy ellipszis.

Tekintsünk egy $O$ origón átmenő síkot, és legyen $\mathcal{I}^{\prime}$ ennek metszete az indikátrix határával. Tekintsük továbbá az $\mathcal{I}^{\prime}$ minimális területú körülírt $\mathcal{E}$ John-Löwnerellipszisét. Indirekt bizonyítást végzünk. Feltéve, hogy $\mathcal{I}^{\prime} \neq \mathcal{E}$, ellentmondásra akarunk jutni. 
Tekintsük a síknak egy olyan affinitását, amely az $O$ origót fixen hagyja, és az $\mathcal{E}$ ellipszist egy $O$ középpontú $\mathcal{C}$ körbe viszi, a $\mathcal{I}^{\prime}$-t pedig egy $\mathcal{I}$ görbébe, amely szimmetrikus az origóra, és a körbe van beleírva. Minthogy minden affinitás megtartja a pontok és az egyenesek illeszkedését, megtartja az egyenesek jobb-merôlegességét is. Erre tekintettel elegendő egy középpontosan szimmetrikus $\mathcal{I}$ görbével és körülírt, $\mathcal{I}$-vel koncentrikus $\mathcal{C}$ körével foglalkoznunk.

Vegyük észre, hogy ezen feltételek mellett a kör egy érintője akkor és csak akkor jobb-meróleges a kör egy másik érintôjére, ha euklideszi értelemben merólegesek, ezért a továbbiakban elhagyjuk az euklideszi jelzôt.

(A2. LÉPÉS) A 2.10. Lemmának megfelelően létezik három különböző pont az $\mathcal{I} \cap \mathcal{C}$ halmazban. A középpontos szimmetriára tekintettel a két görbe metszéspontjai az $O$-ra szimmetrikus párokban fordulnak eló, ezért van legalább négy közös pontunk. Két esetet kell vizsgálnunk aszerint, hogy az $\mathcal{I} \cap \mathcal{C}$ halmaz pontjainak száma (1) 5-nél nem kevesebb, illetve (2) négy.

1. Eset $\mathrm{Az} \mathcal{I}$ és az $\mathcal{E}$ görbéknek van legalább öt közös pontja.

(A3. LÉPÉS) A szimmetrikus görbék közös pontjai átellenes párokat alkotnak, ezért kiválaszthatunk $E_{i}(i=1, \ldots, 5)$ pontokat úgy, hogy $\left(E_{1}, E_{2}\right)$ és $\left(E_{3}, E_{4}\right)$ átellenes pontok legyenek. A közös érintôket ezekben a pontok jelölje rendre $t_{i}$.

Ekkor a $t_{3}$ és $t_{5}$ érintô metszi a $t_{1}$ és $t_{2}$ érintôket, továbbá vagy $t_{3}$, vagy $t_{5}$ nem meróleges rájuk. Ha szükséges, cseréljük fel az indexeket úgy, hogy $t_{3}$ és $t_{2}$ ne legyen meróleges, így feltételezhetjük, hogy van négy $E_{1} \prec E_{4} \prec E_{2} \prec E_{3}$ pontunk sorban a $\mathcal{C}$ körüljárása szerint úgy, hogy $t_{1} \| t_{2}$, és $t_{3}$ nem jobb-meróleges a $t_{2}$-re.

(A4. LÉPÉS) A két különböző görbe középpontos szimmetriájának következményeképpen a $\mathcal{C}\left(E_{1} E_{4}\right)=\mathcal{I}\left(E_{1} E_{4}\right)$ és a $\mathcal{C}\left(E_{4} E_{2}\right)=\mathcal{I}\left(E_{4} E_{2}\right)$ egyenlôség nem állhatnak fenn egyidejúleg, különben $\mathcal{C}=\mathcal{I}$ következne. Így az általánosság megszorítása nélkül feltehetjük, hogy $\mathcal{C}\left(E_{1} E_{4}\right) \neq \mathcal{I}\left(E_{1} E_{4}\right){ }^{11}$

(A5. LÉPÉs) A $t_{2}$ és $t_{3}$ érintôk nem párhuzamosok, mert $E_{2}$ és $E_{3}$ nem átellenes pontok, az $\mathcal{C}\left(E_{1} E_{4}\right)$ nyílt ív minden érintője pedig metszi a $t_{2}$ és $t_{3}$ érintôt is. A 3.3. Lemma az $\mathcal{C}\left(E_{1} E_{4}\right)$ és $\mathcal{I}\left(E_{1} E_{4}\right)$ ívre azt adja, hogy lennie kell olyan $P_{1}^{\mathcal{C}} \in \mathcal{C}\left(E_{1} E_{4}\right)$ és $P_{1}^{\mathcal{I}} \in \mathcal{I}\left(E_{1} E_{4}\right)$ pontoknak, amelyekre

(i) $O P_{1}^{\mathcal{C}} \nVdash O P_{1}^{\mathcal{I}}$;

(ii) ezekben a pontokban a $t_{1}^{\mathcal{C}}$, illetve $t_{1}^{\mathcal{I}}$ érintôk párhuzamosak.

Továbbá az is igaz, hogy

(iii) $t_{1}^{\mathcal{C}}$ és $t_{1}^{\mathcal{I}}$ metszi mind a $t_{2}$, mind a $t_{3}$ érintôt; és

(iv) $O P_{1}^{\mathcal{C}}$, illetve $O P_{1}^{\mathcal{I}}$ nem merôleges a $t_{3}, t_{2}$ egyikére sem, ha ugyanis nem így lenne, akkor egy $P_{1}^{\mathcal{C}}$-hez elég közeli pont választható $P_{1}^{\mathcal{C}}$ helyett.

\footnotetext{
${ }^{11} \mathrm{Ha} \mathcal{C}\left(E_{1} E_{4}\right) \neq \mathcal{I}\left(E_{1} E_{4}\right)$, akkor felcserélhetjük az 1 és 2 indexeket anélkül, hogy megszüntetnénk a $t_{3}$ és $t_{2}$ nem merôleges viszonyát.
} 
(A6. LÉPÉs) Legyen $M_{1}=t_{2} \cap t_{3}, M_{2}^{\mathcal{C}}=t_{1}^{\mathcal{C}} \cap t_{3}, M_{3}^{\mathcal{C}}=t_{1}^{\mathcal{C}} \cap t_{2}, M_{2}^{\mathcal{I}}=$ $t_{1}^{\mathcal{I}} \cap t_{3}, M_{3}^{\mathcal{I}}=t_{1}^{\mathcal{I}} \cap t_{2}$, és jelölje az $M_{1} M_{2}^{\mathcal{I}} M_{3}^{\mathcal{I}} \triangle$ trigon oldalainak felezópontjait $B_{3}^{\mathcal{I}}, B_{1}^{\mathcal{I}}, B_{2}^{\mathcal{I}} ;$ az $M_{1} M_{2}^{\mathcal{C}} M_{3}^{\mathcal{C}} \triangle$ trigon oldalainak felezópontjait $B_{3}^{\mathcal{C}}, B_{1}^{\mathcal{C}}$, illetve $B_{2}^{\mathcal{C}}$ (lásd az 5.1. Ábrát).

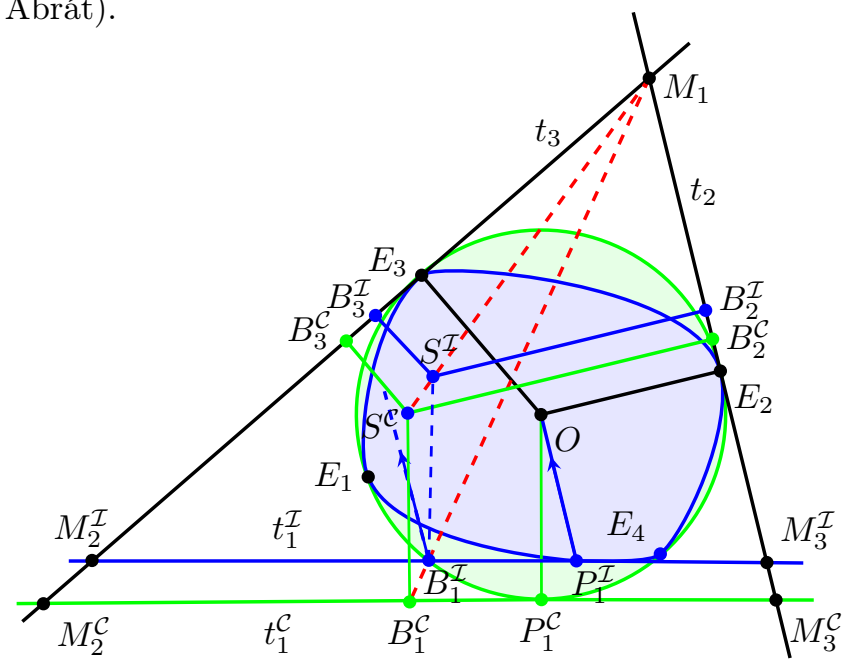

5.1. Ábra. Jobb-merôleges oldalfelezők, ha $S^{\mathcal{C}} \neq P_{1}^{\mathcal{C}}$

Az $M_{1} M_{2}^{\mathcal{C}} M_{3}^{\mathcal{C}} \triangle$ trigon euklideszi oldalfelező merólegeseinek van egy közös $S^{\mathcal{C}}$ pontja. Ez különbözik $B_{i}^{\mathcal{C}}$-tôl, minthogy a trigon nem derékszögú háromszög. Továbbá az is igaz, hogy $B_{i}^{\mathcal{C}} S^{\mathcal{C}} \| E_{i} O$ az $i=2,3$ indexekre, és $B_{1}^{\mathcal{C}} S^{\mathcal{C}} \| P_{1}^{\mathcal{C}} O$.

A feltevés szerint az $M_{1} M_{2}^{\mathcal{I}} M_{3}^{\mathcal{I}} \triangle$ trigon $B_{3}^{\mathcal{I}}$, illetve $B_{2}^{\mathcal{I}}$ felezópontokon átmenô jobb-merôleges oldalfelezőinek metszéspontja $S^{\mathcal{I}}$, az $M_{1} M_{2}^{\mathcal{I}} M_{3}^{\mathcal{I}} \triangle$ trigon jobbbiszektorális centruma. Az $M_{1} M_{2}^{\mathcal{C}} M_{3}^{\mathcal{C}} \triangle$ és $M_{1} M_{2}^{\mathcal{I}} M_{3}^{\mathcal{I}} \triangle$ háromszögek középpontosan hasonlóak az $M_{1}$ pontra vonatkozóan, mivel $t_{1}^{\mathcal{C}} \| t_{1}^{\mathcal{I}}$. Ez a $\chi$ hasonlóság a $B_{i}^{\mathcal{C}}$ pontot a $B_{i}^{\mathcal{I}}$ pontba viszi $(i=1,2,3)$, ezért a $B_{i}^{\mathcal{C}} S^{\mathcal{C}}$ egyeneseket a velük párhuzamos, a $B_{i}^{\mathcal{I}}$ pontokon átmenő egyenesekbe viszi $(i=2,3)$. Így $\chi$ az $S^{\mathcal{C}}$ metszéspontot az $S^{\mathcal{I}}$ metszéspontba viszi, ahol $S^{\mathcal{C}}$ különbözik $B_{i}^{\mathcal{I}}$ pontoktól. Következésképpen azt kaptuk, hogy $P_{1}^{\mathcal{C}} O\left\|B_{1}^{\mathcal{C}} S^{\mathcal{C}}\right\| B_{1}^{\mathcal{I}} S^{\mathcal{I}}$. A $B_{1}^{\mathcal{I}}$ felezőponton átmenô jobb-meróleges felezô egyenesnek át kell mennie az $S^{\mathcal{I}}$ ponton, amely metszéspontja a másik két jobb-merôleges oldalfelezô egyenesnek, és így egyrészt párhuzamos a $P_{1}^{\mathcal{C}} O$ egyenessel, másrészt párhuzamos a $P_{1}^{\mathcal{I}} O$ egyenessel a jobb-merólegesség definíciója szerint. $\mathrm{Ez}$ az ellentmondás igazolja a Tételt ebben az esetben.

2. Eset. Az $\mathcal{I}$ és $\mathcal{C}$ görbéknek pontosan négy közös pontja van.

(A7. LÉPÉS) Úgy számozhatjuk meg a közös pontokat, hogy a $\mathcal{C}$ egy körüljárásában a sorrendjük $E_{1} \prec E_{4} \prec E_{2} \prec E_{3}$ legyen. 
Ha $O E_{2}$ nem meróleges $O E_{3}$-ra, akkor az e pontbeli érintőkre $t_{1} \| t_{2}$, és $t_{3}$ nem jobb-meróleges a $t_{2}$ érintőre.

Továbbá a következố nyílt íveknek nincsen közös pontja, vagyis $\mathcal{C}\left(E_{1} E_{4}\right) \cap$ $\mathcal{I}\left(E_{1} E_{4}\right)=\emptyset$, és $\mathcal{C}\left(E_{4} E_{2}\right) \cap \mathcal{I}\left(E_{4} E_{2}\right)=\emptyset$.

Így visszaléphetünk az $\mathrm{A} 4$. lépés végéhez, folytathatjuk az $\mathrm{A} 5$. lépéssel, és a bizonyítás teljessé tételéhez befejezhetjük a A6. lépéssel.

(A8. LÉPÉs) Ha $O E_{2}$ merôleges $O E_{3}$-ra, akkor közös átellenes pontokból álló két párral van dolgunk, melyekre teljesül, hogy $E_{1} \prec E_{4} \prec E_{2} \prec E_{3}$ a $\mathcal{C}$ egy körüljárásában, és hogy a megfelelő pontbeli $t_{3}$ érintő meróleges a $t_{2}$ érintőre.

Ha alkalmazzuk a 3.3. Lemmát az $\mathcal{C}\left(E_{3} E_{1}\right)$ és $\mathcal{I}\left(E_{3} E_{1}\right)$ nyílt ívekre, akkor találhatunk olyan $P_{3}^{\mathcal{C}}, P_{3}^{\mathcal{I}}$ pontokat az $O$-val egy egyenesen, amelyekben a $\mathcal{C}$, illetve $\mathcal{I}$ görbéhez húzott $t_{3}^{\mathcal{C}}$, illetve $t_{3}^{\mathcal{I}}$ érintô párhuzamos. Az is teljesül, hogy ezek az érintők nem párhuzamosak a $t_{2}$ érintôvel. Jelölje $\alpha_{3}$ az $\varangle\left(E_{3} O P_{3}^{\mathcal{C}}\right)$ szöget.

(A9. LÉPÉs) Alkalmazhatjuk a 3.2. Lemmát az $\mathcal{C}\left(E_{4} E_{1}\right)$ és $\mathcal{I}\left(E_{4} E_{1}\right)$ ívekre, hogy találjunk olyan $P_{1}^{\mathcal{C}}$, illetve $P_{1}^{\mathcal{I}}$ pontokat a megfeleló íveken az $E_{4}$ ponthoz tetszólegesen közel úgy, hogy

(i) $O P_{1}^{\mathcal{C}} \| O P_{1}^{\mathcal{I}}$,

(ii) a $\mathcal{C}$, illetve $\mathcal{I}$ görbe $t_{1}^{\mathcal{C}}$, illetve $t_{1}^{\mathcal{I}}$ érintője e pontokban nem párhuzamos,

(iii) $t_{1}^{\mathcal{C}} \cap t_{1}^{\mathcal{I}}$ közel van az $E_{4}$ ponthoz, mégpedig az $O P_{1}^{\mathcal{C}}$ egyenesnek ugyanazon az oldalán, mint ahol az $E_{4}$ pont van.

A $P_{1}^{\mathcal{C}}$ pontot választhatjuk az $E_{4}$ ponthoz olyan közel, hogy a $\varangle\left(P_{1}^{\mathcal{C}} O E_{4}\right)$ szög $\alpha_{1}$ nagysága kisebb, mint $\min \left(\alpha_{3}, \pi / 2-\alpha_{3}\right)$.

(A10. LÉPÉS) A $t_{1}^{\mathcal{C}}$ metszi a $t_{2}$ érintôt egy $M_{3}^{\mathcal{C}}$ pontban, mivel $t_{4}$ is metszi, és a $t_{1}^{\mathcal{C}}$ és $t_{4}$ érintô iránya is közel van egymáshoz. A $t_{1}^{\mathcal{I}}$ hasonló okból metszi a $t_{2}$ érintót egy $M_{3}^{\mathcal{I}}$ pontban, a $\varangle P_{1}^{\mathcal{C}} M_{3}^{\mathcal{C}} E_{2}$ és $\varangle P_{1}^{\mathcal{I}} M_{3}^{\mathcal{I}} E_{2}$ szögek pedig egyaránt hegyesszögek.

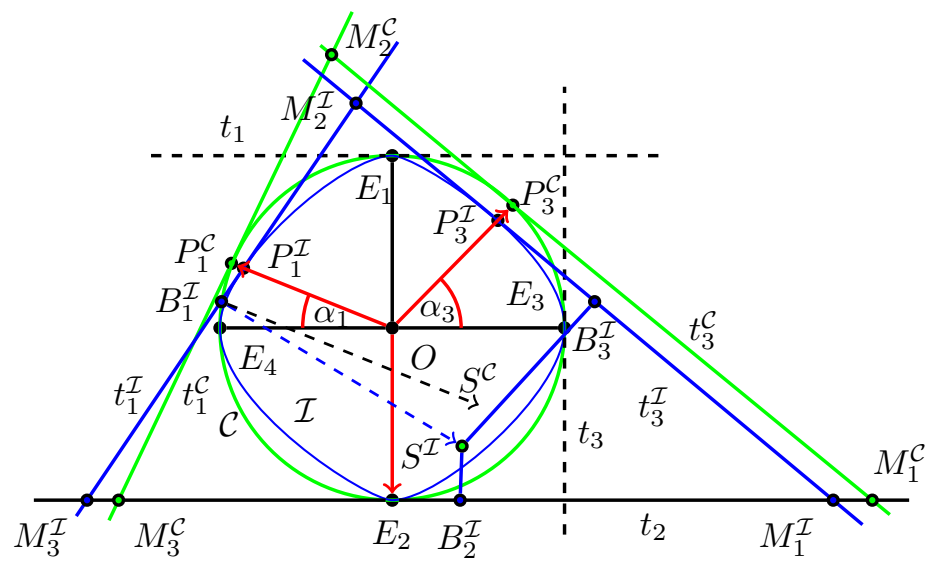

5.2. Ábra. A 2. eset: ha a $t_{3}$ és $t_{2}$ érintôk merôlegesek 
A $t_{3}^{\mathcal{C}}$ metszi a $t_{2}$ érintôt egy $M_{1}^{\mathcal{C}}$ pontban, a $t_{3}^{\mathcal{I}}$ metszi a $t_{2}$ érintôt egy $M_{1}^{\mathcal{I}}$ pontban, mivel $0<\alpha_{3}<\pi / 2$, továbbá a $\varangle P_{3}^{\mathcal{C}} M_{1}^{\mathcal{C}} E_{2}, \varangle P_{3}^{\mathcal{I}} M_{1}^{\mathcal{I}} E_{2}$ szögek hegyesek, és a $\varangle P_{3}^{\mathcal{C}} O P_{1}^{\mathcal{C}}$ szög tompa. Eszerint a $t_{1}^{\mathcal{C}}$ metszi a $t_{3}^{\mathcal{C}}$ érintôt egy $M_{2}^{\mathcal{C}}$ pontban, és a $\varangle P_{3}^{\mathcal{C}} M_{2}^{\mathcal{C}} P_{1}^{\mathcal{C}}$ szög hegyes. Mivel a $t_{1}^{\mathcal{C}}$ és $t_{1}^{\mathcal{I}}$ iránya csak egy kicsit különbözik, $t_{1}^{\mathcal{I}}$ és $t_{3}^{\mathcal{I}}$ metszi egymást egy $M_{2}^{\mathcal{I}}$ pontban (lásd az 5.2. Ábrát).

Eszerint az $M_{1}^{\mathcal{C}} M_{2}^{\mathcal{C}} M_{3}^{\mathcal{C}} \triangle$ és $M_{1}^{\mathcal{I}} M_{2}^{\mathcal{I}} M_{3}^{\mathcal{I}} \triangle$ is létezik, és minden szöge hegyes.

(A11. LÉPÉs) Jelölje a trigon $M_{i}^{\mathcal{I}}$ csúccsal szemközti oldalának felezôpontját $B_{i}^{\mathcal{I}}(i=1,2,3)$. A $B_{2}^{\mathcal{I}}$ és $B_{3}^{\mathcal{I}}$ pontokon átmenó jobb-meróleges oldalfelezók egybeesnek az euklideszi oldalfelezô merólegesekkel, és metszéspontjuk $S^{\mathcal{I}}$. Ez a pont az $M_{1}^{\mathcal{I}} M_{2}^{\mathcal{I}} M_{3}^{\mathcal{I}} \triangle$ trigon euklideszi körülírt körének középpontja, és egyben jobbmerőleges biszektorális centrum is, amely különbözik mindegyik $B_{i}^{\mathcal{I}}$ felezôponttól, minthogy a háromszögnek nincsen derékszöge. Így $B_{1}^{\mathcal{I}} S^{\mathcal{I}}$ a harmadik euklideszi oldalfelező merôleges, amely meróleges a $t_{1}^{\mathcal{I}}$ érintőre. Ugyanakkor a $B_{1}^{\mathcal{I}} S^{\mathcal{I}}$ egyenesnek a harmadik jobb-meróleges oldalfelezónek kell lennie, amely párhuzamos a $P_{1}^{\mathcal{I}} O$ egyenessel, és következésképpen merőleges a $t_{1}^{\mathcal{C}}$ érintôre. De a $t_{1}^{\mathcal{I}}$ és $t_{1}^{\mathcal{C}}$ érintők nem párhuzamosak, ami ellentmondás, a bizonyítás pedig teljes.

5.2. Tétel. ([Km, Theorem 3.2]) Egy Minkowski-geometria akkor és csak akkor euklideszi, ha minden háromszögre a jobb-meróleges magasságvonalak konkurensek.

Bizonyítás. A szükségesség világos, így csak elegendőséget kell igazolnunk.

(B1. LÉPÉS) Az 5.1. Tétel A1. és A2. lépései alapján két eset van.

1. Eset. $|\mathcal{C} \cap \mathcal{I}| \geq 5$. (Az 5.3. Ábrán a $\mathcal{C} \cap \mathcal{I}$ metszetnek csak négy pontja látszik.)

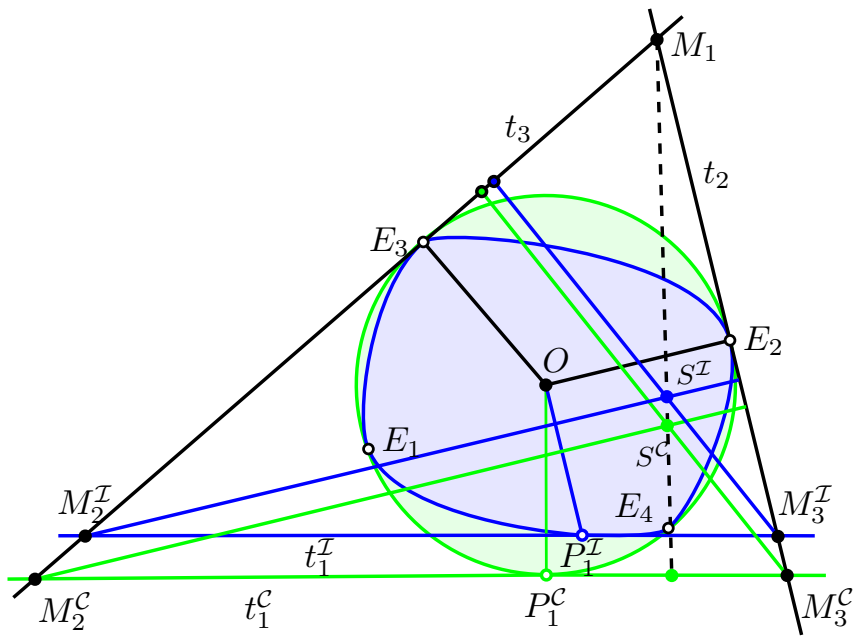

5.3. Ábra. Magasságvonalak az elsố esetben 
(B2. LÉPÉs) Pontosan úgy, mint az 5.1. Tétel bizonyítása során, annak A3.A5. lépéseivel olyan konfigurációhoz juthatunk, ahol a $P_{1}^{\mathcal{C}} \in \mathcal{C}$ és $P_{1}^{\mathcal{I}} \in \mathcal{I}$ pontbeli érintôk párhuzamosak, ugyanakkor az $O P_{1}^{\mathcal{I}}$ és $O P_{1}^{\mathcal{C}}$ egyenesek nem párhuzamosak, amelyen az érintők metszéspontjait ugyanúgy jelöltük, mint előzőleg.

(B3. LÉPÉS) Az $M_{1} M_{2}^{\mathcal{C}} M_{3}^{\mathcal{C}} \triangle$ trigon jobb-meróleges magasságvonalainak van egy közös $S^{\mathcal{C}}$ pontja, minthogy a konfiguráció tulajdonságai szerint azok egyben euklideszi magasságvonalak is, továbbá $M_{i}^{\mathcal{C}} S^{\mathcal{C}} \| E_{i} O$ az $i=2,3$ indexekre, és $M_{1}^{\mathcal{C}} S^{\mathcal{C}} \| O P_{1}^{\mathcal{C}}$.

Jelöljük az $M_{1} M_{2}^{\mathcal{I}} M_{3}^{\mathcal{I}} \triangle$ trigon $M_{3}^{\mathcal{I}}$, illetve $M_{2}^{\mathcal{I}}$ csúcsain átmenő jobbmagasságainak metszéspontját $S^{\mathcal{I}}$-vel. Mivel az $M_{1} M_{3}^{\mathcal{C}} M_{2}^{\mathcal{C}} \triangle$ és $M_{1} M_{3}^{\mathcal{I}} M_{2}^{\mathcal{I}} \triangle$ trigonok nyilvánvalóan középpontosan hasonlóak az $M_{1}$ centrummal, az $M_{1}, S^{\mathcal{I}}, S^{\mathcal{C}}$ pontok egy egyenesre esnek, és nyilvánvalóan különbözôek. Így az $M_{1} S^{\mathcal{I}}$ párhuzamos a $P_{1}^{\mathcal{C}} O$ egyenessel. Másrészt a jobb-merólegesség definíciójára tekintettel a harmadik jobb-magasság párhuzamos a $P_{1}^{\mathcal{I}} O$ egyenessel. Ez egy ellentmondás, amely igazolja a tételt ebben az elsô esetben.

2. Eset $|\mathcal{C} \cap \mathcal{I}|=4$.

(B4. LÉPÉS) Az A7. lépéssel folytathatjuk, és lezárhatjuk a bizonyítást, amikor $E_{2}$ és $E_{3}$ nem merólegesek.

(B5. LÉPÉs) Már csak azt az esetet kell tekinteni, amikor $t_{3}$ meróleges (és egyben jobb-merôleges is) a $t_{2}$ érintôre.

A $\mathcal{C}$ görbén válasszuk a $P_{1}^{\mathcal{C}}$, illetve $P_{3}^{\mathcal{C}}$ pontokat az $E_{1}$, illetve $E_{3}$ ponthoz közel úgy, hogy $\left|\varangle\left(E_{1} O P_{1}^{\mathcal{C}}\right)\right|=\left|\varangle\left(E_{3} O P_{3}^{\mathcal{C}}\right)\right|=\alpha$ teljesüljön, és a szögek azonos módon irányítottak. A $\mathcal{C}$ görbéhez ezekben a pontokban húzott érintóket jelölje $t_{i}^{\mathcal{C}}$ $(i=1,3)$, az $\bar{O} P_{i}^{\mathcal{C}}$ félegyeneseknek a $\mathcal{I}$ görbén lévő pontját pedig $P_{i}^{\mathcal{I}}(i=1,3)$. $\mathrm{Az}$ $\mathcal{I}$ görbéhez ezen pontokon keresztül húzott érintók jelölése $t_{i}^{\mathcal{I}}(i=1,3)$ (lásd az 5.4. Ábrát).

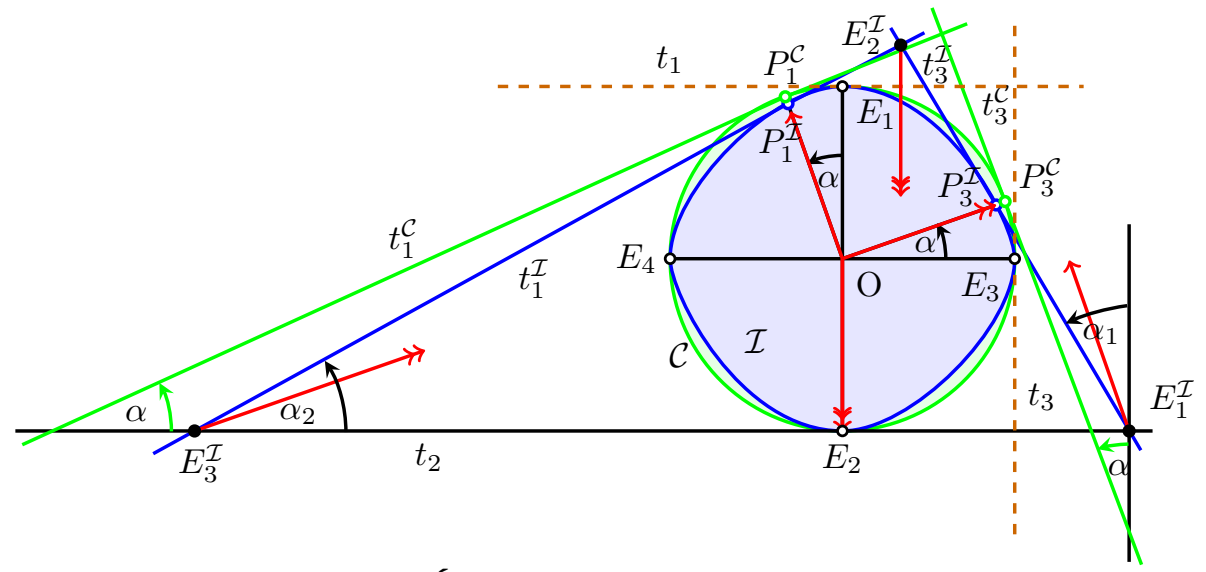

5.4. Ábra. 2. eset: amikor $E_{2} \perp E_{3}$ 
Világos, hogy a $t_{1}^{\mathcal{C}}, t_{3}^{\mathcal{C}}$ és $t_{2}$ érintő́k egy trigont határoznak meg, mint ahogyan a $t_{1}^{\mathcal{I}}, t_{3}^{\mathcal{I}}$ és $t_{2}$ érintók az $M_{1}^{\mathcal{I}} M_{2}^{\mathcal{I}} M_{3}^{\mathcal{I}} \triangle$ trigon oldalegyenesei.

A $t_{1}^{\mathcal{C}}$ és $t_{2}$ egyenesek által bezárt szög nyilvánvalóan $\alpha$, ugyanúgy, mint a $t_{3}^{\mathcal{C}}$ egyenes és az $O E_{1}$ egyenesek szöge. A 3.2. Lemma következményeként megállapítható, hogy a $t_{1}^{\mathcal{I}}$ és $t_{2}$ által bezárt $\alpha_{2}$ szög nagyobb, mint $\alpha$; és hasonlóképpen a $t_{3}^{\mathcal{I}}$ és $O E_{1}$ közötti $\alpha_{1}$ nagyobb, mint $\alpha$.

A jobb-merôlegességnek megfelelően az $M_{1}^{\mathcal{I}} M_{2}^{\mathcal{I}} M_{3}^{\mathcal{I}} \triangle$ trigon jobb-magasságai rendre párhuzamosak az $O P_{1}^{\mathcal{I}}, O P_{3}^{\mathcal{I}}, O E_{2}$ egyenesekkel, így az $M_{1}^{\mathcal{I}}$ csúcson átmenő magasság az $M_{2}^{\mathcal{I}}$ csúcson átmenô magasságot a háromszögön kívül metszi, míg az $M_{3}^{\mathcal{I}}$ csúcson átmenő magasság az $M_{2}^{\mathcal{I}}$ csúcson átmenô magasságot a háromszög belsejében metszi. Ebból következik, hogy a három magasság nem mehet át egy ponton. Ez bizonyítja a Tételt erre az utolsó estre.

\subsection{Karakterizáció bal-biszektorális és bal-ortocentrummal}

Először a bal-merôleges oldalfelezó egyenesek, majd a bal-meróleges magasságvonalak konkurenciáját vizsgáljuk.

5.3. Tétel. ([Km, Theorem 4.1]) Egy Minkowski-geometria akkor és csak akkor euklideszi, ha minden trigon bal-meróleges oldalfelezố egyenesei konkurensek.

Bizonyítás. Nyilván elegendô a szükségességet igazolnunk.

(C1. LÉPÉS) Megismételhetjük az 5.1. Tétel A1. lépését, és kapunk egy középpontosan szimmetrikus, kétszeresen differenciálható $\mathcal{I}$ görbét, valamint annak körülírt $\mathcal{C}$ körét, mely vele koncentrikus (ez a görbe John-Löwner-ellipszise).

Most olyan trigont konstruálunk, amelynek három oldalfelező bal-merőlegese nem mehet át egy ponton. Ennek léte igazolja az állítást.

(C2. LÉPÉS) A 2.10. Lemma szerint létezik legalább három pont a $\mathcal{I} \cap \mathcal{C}$ halmazban. A 2.10. Lemma (2) része szerint pedig a közös pontok közül (legalább) egynek tetszőlegesen kis környezetében a görbék különböznek. Mivel a közös pontok átellenes párokban fordulnak elő, van négy különbözô közös $E_{i}$ pont úgy, hogy

(1) $E_{2}$ és $E_{1}$ átellenes pontok;

(2) $E_{3}$ és $E_{4}$ átellenes pontok;

(3) $E_{1}$ olyan, hogy hozzá tetszőlegesen közel vannak olyan különböző $P_{1}^{\mathcal{C}} \in \mathcal{C}$ és $P_{1}^{\mathcal{I}} \in \mathcal{I}$ pontok, amelyek az $O$-ból kiinduló ugyanazon félegyenesen vannak, és e pontokban az $\mathcal{C}$ görbe $t_{1}^{\mathcal{C}}$, illetve a $\mathcal{I}$ görbe $t_{1}^{\mathcal{I}}$ érintôje metszik egymást a $P_{1}^{\mathcal{C}} P_{1}^{\mathcal{I}}$ egyenesnek azon az oldalán, ahol $E_{1}$ van (lásd a 3.2. Lemmát);

(4) a $\mathcal{C}$ görbe egy körüljárásában a pontok sorrendje $E_{1} \prec P_{1}^{\mathcal{C}} \prec E_{4} \prec E_{2} \prec E_{3}$. 
Jelölje a görbék közös $E_{i}$ pontbeli közös érintőit $t_{i}(i=2,3)$. A kör $t_{1}^{\mathcal{C}}, t_{2}$, illetve $t_{3}$ érintôje euklideszi értelemben meróleges az $O P_{1}^{\mathcal{C}}, O E_{2}$, illetve $O E_{3}$ egyenesre, ezért közülük semelyik kettô sem párhuzamos. Mivel a $t_{1}^{\mathcal{C}}$ és $t_{1}^{\mathcal{I}}$ iránya közel van egymáshoz, a $P_{1}^{\mathcal{C}}$ pontot megfelelóen közelinek választva az $E_{1}$ ponthoz, a $t_{1}^{\mathcal{I}}$ érintő metszi a $t_{2}$ és $t_{3}$ érintôket is (lásd az 5.5. Ábra bal oldali részét). A bal-merólegesség definíciójának megfelelóen a $t_{1}^{\mathcal{I}}$ egyenes bal-merôleges az $O P_{1}^{\mathcal{I}}$ egyenesre.

$\mathrm{Az} \overrightarrow{O P_{1}^{\mathrm{C}}}, \overrightarrow{O E_{2}}$ és $\overrightarrow{O E_{3}}$ vektorok nyilvánvalóan lineárisan függetlenek, így választható úgy egy $A_{1} A_{2} A_{3} \triangle$ háromszög, hogy $A_{3} A_{2}\left\|O P_{1}^{\mathcal{C}}, A_{2} A_{1}\right\| O E_{3}$, $A_{1} A_{3} \| O E_{2}$, és az $A_{1}, A_{2}, A_{3}$ csúcsok körüljárása ugyanaz, mint az $E_{3}, P^{\mathcal{C}}, E_{2}$ pontoké (lásd az 5.5. Ábra jobb oldali részét).

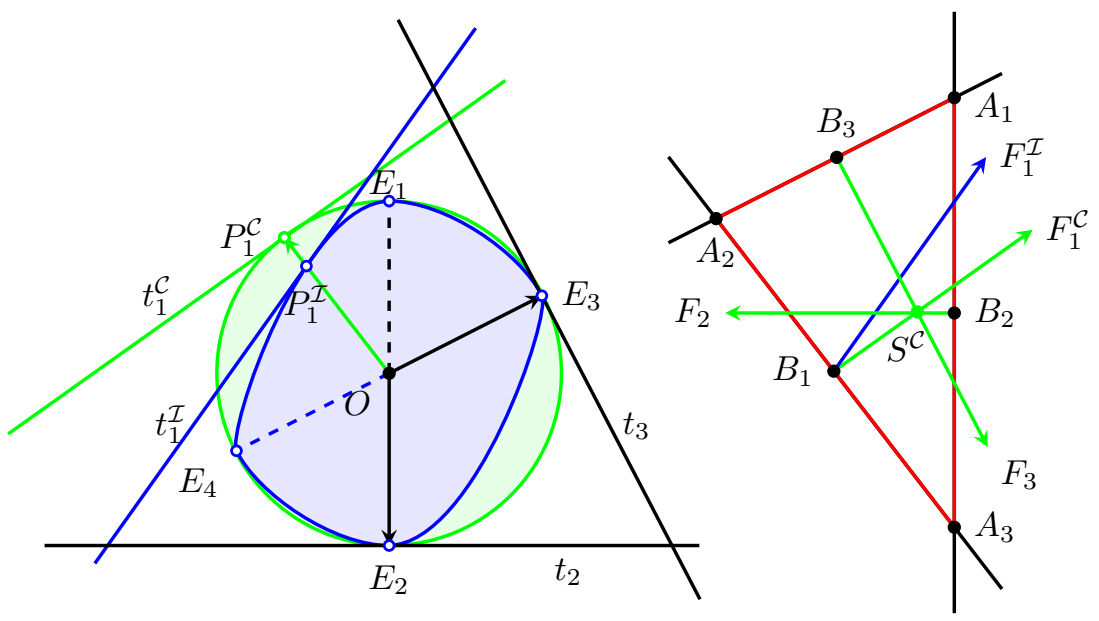

5.5. Ábra. Bal-merőleges oldalfelezók, ha $S^{\mathcal{C}} \neq B_{1}$.

1. eset. Az $\overrightarrow{O E_{2}}$ és $\overrightarrow{O E_{3}}$ vektorok nem merólegesek.

(C3. LÉPÉs) Jelölje az $A_{1} A_{2} A_{3} \triangle$ háromszög $\overline{A_{i} A_{j}}$ oldalainak felezőpontjait $B_{k},\{i, j, k\}=\{1,2,3\}$ (lásd az 5.5. Ábra jobb oldali részét).

Vegyünk olyan $B_{1} F_{1}^{\mathcal{C}}, B_{2} F_{2}$, illetve $B_{3} F_{3}$ egyeneseket, hogy $B_{1} F_{1}^{\mathcal{C}}\left\|t_{1}^{\mathcal{C}}, B_{2} F_{2}\right\|$ $t_{2}$, illetve $B_{3} F_{3} \| t_{3}$. Mivel ezek az egyenesek (euklideszi értelemben) merőlegesek a trigonban a nekik megfelelô oldalakra, van egy $S^{\mathcal{C}}$ közös pontjuk, amely az euklideszi körülírt kör középpontja. Mivel az $O E_{2}$ és $O E_{3}$ egyenesek nem merólegesek, az $A_{2} A_{1}$ és $A_{3} A_{1}$ egyenesek szintén nem merólegesek, így $S^{\mathcal{C}} \neq B_{1}$.

Tekintsük most a $B_{1} F_{1}^{\mathcal{I}} \| t_{1}^{\mathcal{I}}$ egyenest. Ennek át kell mennie a feltevés szerint az $A_{1} A_{2} A_{3} \triangle$ trigon $S^{\mathcal{I}}=B_{2} F_{2} \cap B_{3} F_{3}$ bal-biszektorális centrumán. Mivel $S^{\mathcal{C}}=$ $B_{2} F_{2} \cap B_{3} F_{3}$, és $S^{\mathcal{C}} \neq B_{1}$, azt kapjuk, hogy $B_{1} F_{1}^{\mathcal{I}}=B_{1} F_{1}^{\mathcal{C}}$. Azonban ez ellentmond annak, hogy $t_{1}^{\mathcal{I}} \nVdash t_{1}^{\mathcal{C}}$, ami bizonyítja a Tételt erre az esetre. 
2. eset. Az $E_{2}$ és $E_{3}$ vektorok merólegesek.

(C4. LÉPÉS) Ha az $E_{1}, E_{3}$ és $E_{2}, E_{4}$ pontpárokon túl további átellenes pontpár is van a $\mathcal{C} \cap \mathcal{I}$ halmazban, és $E_{6} \in\left(\mathcal{C}\left(E_{1}, E_{2}\right)\right.$ az egyik ilyen pár pontja, akkor a 6 és 3 indexek felcserélésével egy olyan konfigurációhoz juthatunk, amelyben $t_{3}$ és $t_{2}$ nem merőlegesek, és ekkor a bizonyítás az A3. lépés szerint zárul.

(C5. LÉPÉS) Ha $\mathcal{C} \cap \mathcal{I}=\left\{E_{1}, E_{2}, E_{3}, E_{4}\right\}$, akkor az 5.1. Tétel bizonyításában a második eset B4. lépését kell követnünk. Tekintsük az 5.6. Ábra konfigurációját, amely egy megfelelően módosított változata az 5.4. Ábra konfigurációjának.
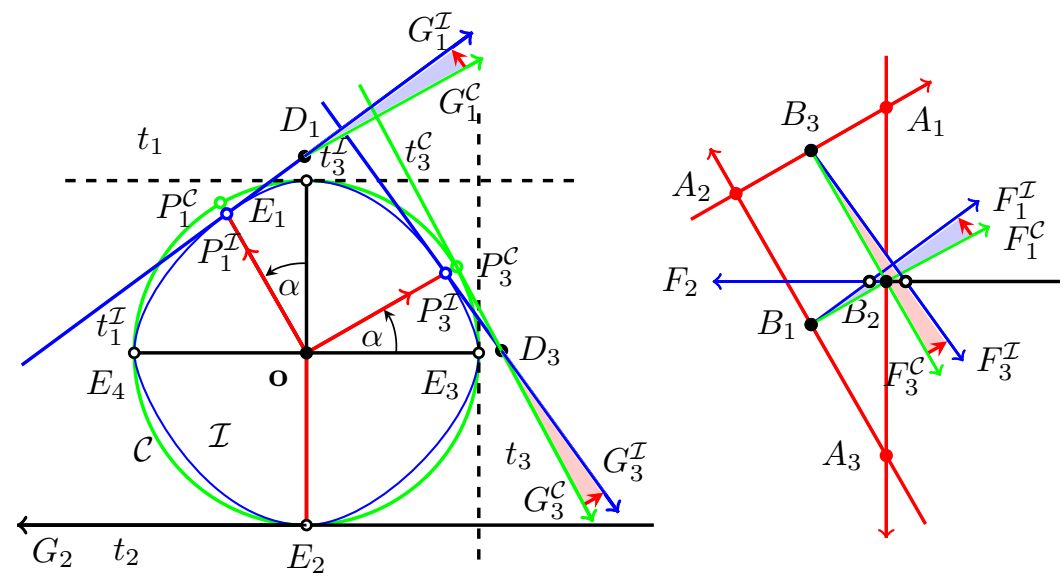

5.6. Ábra. Bal-merőleges oldalfelezők, ha $\mathbf{s}^{\mathcal{C}}=B_{1}$

Tekintsük a $D_{i}=t_{i}^{\mathcal{C}} \cap t_{i}^{\mathcal{I}}(i=1,3)$ pontokat, és vezessük be a $\bar{D}_{i} G_{i}^{\mathcal{C}}$ és $\bar{D}_{i} G_{i}^{\mathcal{I}}$ $(i=1,3)$ jelöléseket a $D_{i}$ pontokból kiinduló azon félegyenesekre a megfeleló érintő egyeneseken, amelyek nem tartalmazzák az érintési pontot. Világos, hogy az irányított $\varangle\left(G_{i}^{\mathcal{C}} D_{1} G_{i}^{\mathcal{I}}\right)$ szögeknek az irányítása megfelel a $\mathcal{C}$ és $\mathcal{I}$ görbék körüljárásának.

(C6. LÉPÉS) Tekintsük a $\bar{B}_{1} F_{1}^{\mathcal{C}}\left\|\bar{D}_{1} G_{1}^{\mathcal{C}}, \bar{B}_{2} F_{2}\right\| \bar{E}_{2} G_{2}$ és $\bar{B}_{3} F_{3}^{\mathcal{C}} \| \bar{D}_{3} G_{3}^{\mathcal{C}}$ félegyeneseket. Ezeknek a félegyeneseknek az egyenesei a derékszögú $A_{1} A_{2} A_{3} \triangle$ háromszög megfelelố oldalainak oldalfelezô merólegesei, ezért euklideszi tulajdonságuk szerint átmennek a háromszög köré írt kör $B_{2}$ középpontján.

A $\bar{B}_{1} F_{1}^{\mathcal{I}} \| \bar{D}_{1} G_{1}^{\mathcal{I}}$ és $\bar{B}_{3} F_{3}^{\mathcal{I}} \| \bar{D}_{3} G_{3}^{\mathcal{I}}$ félegyenesek egyenesei bal-meróleges oldalfelezôi az $A_{1} A_{2} A_{3} \triangle$ trigon megfeleló oldalainak, ezért a feltevés szerint egy ponton mennek át, a trigon bal-biszektorális centrumán.

Figyelembe véve az irányított $\varangle\left(F_{1}^{\mathcal{C}} B_{1} F_{1}^{\mathcal{I}}\right)$ és $\varangle\left(F_{3}^{\mathcal{C}} B_{3} F_{3}^{\mathcal{I}}\right)$ szögek irányítását, azt találjuk, hogy a $\bar{B}_{1} F_{1}^{\mathcal{I}}$ és $\bar{B}_{3} F_{3}^{\mathcal{I}}$ félegyenesek az $B_{2} F_{2}$ egyenest a $B_{2}$ pontjának ellentétes oldalain metszik. Így a trigon három bal-merőleges oldalfelezô egyenese nem mehet át egy ponton. Ez az ellentmondás bizonyítja a tételünket ebben az esetben, és ezzel a bizonyítás teljes. 
A bal-meróleges magasságvonalak metszéspontjának a vizsgálata van hátra.

5.4. Tétel. ([Km, Theorem 4.2]) Egy Minkowski-geometria akkor és csak akkor euklideszi, ha minden trigon bal-meróleges magasságvonalai konkurensek.

Bizonyítás. Elegendôség. Euklideszi geometriában a bal-merôlegesek egyben merôlegesek euklideszi értelemben is, ezért a bal-magasságvonalak egyenesei a magasságvonalakéival egyeznek meg, s ezért konkurensek.

Szükségesség. Feltesszük, hogy minden trigonban egy ponton mennek át a bal-meróleges magasságvonalak.

(D1. LÉPÉS) Megismételhetjük az előző bizonyítás C1—C3. lépéseit. Ekkor — amint ott is - megkonstruálhatunk egy $A_{1} A_{2} A_{3} \triangle$ trigont úgy, hogy $A_{1} A_{2} \| O E_{3}$, $A_{2} A_{3}\left\|O P_{1}^{\mathcal{C}}, A_{3} A_{1}\right\| O E_{2}$ teljesüljön, továbbá az $A_{1} A_{2} A_{3} \triangle$ körüljárása ugyanaz, mint az $E_{3}, P_{1}^{\mathcal{C}}, E_{2}$ pontoké.

Két esetet kell megvizsgálnunk.

1. eset. Az $O E_{2}$ és $O E_{3}$ egyenesek nem merólegesek.
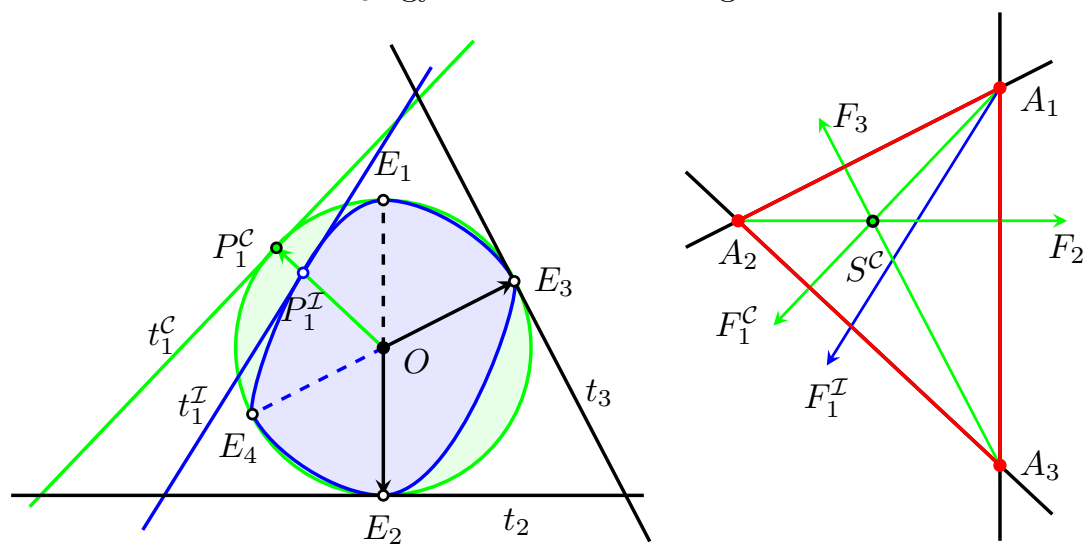

5.7. Ábra. Bal-merőlegesség és magasságok, amikor $S^{\mathcal{C}} \neq A_{2}$

(D2. LÉPÉs) Hasonló megfontolásokat alkalmazunk, mint a C3. lépés során.

Válasszuk az $A_{1} F_{1}^{\mathcal{C}}, A_{2} F_{2}$ és $A_{3} F_{3}$ egyeneseket úgy, hogy $A_{1} F_{1}^{\mathcal{C}}\left\|t_{1}^{\mathcal{C}}, A_{2} F_{2}\right\| t_{2}$, és $A_{3} F_{3} \| t_{3}$. Ezek euklideszi értelemben merólegesek a trigon megfelelő szemközti oldalára, így átmennek annak euklideszi $S^{\mathcal{C}}$ magasságpontján.

Tekintsük most az $A_{1} F_{1}^{\mathcal{I}} \| t_{1}^{\mathcal{I}}$ egyenest. Az $A_{1} F_{1}^{\mathcal{I}}, A_{2} F_{2}$ és $A_{3} F_{3}$ egyenesek az $A_{1} A_{2} A_{3} \triangle$ trigon bal-meróleges magasságvonalainak egyenesei, ezért a feltevés szerint egy ponton mennek át: a trigon $S^{\mathcal{I}}$ bal-ortocentrumán.

Mivel $t_{1}^{\mathcal{C}} \nVdash t_{1}^{\mathcal{I}}$, teljesül az, hogy $A_{1} F_{1}^{\mathcal{C}} \neq A_{1} F_{1}^{\mathcal{I}}$. Ám ez ellentmond annak, hogy $S^{\mathcal{C}}=A_{2} F_{2} \cap A_{3} F_{3}=S^{\mathcal{I}}$, mivel $A_{1} \neq S^{\mathcal{C}} \in A_{1} F_{1}^{\mathcal{C}} \cap A_{1} F_{1}^{\mathcal{I}}=\left\{A_{1}\right\}$. Ez az ellentmondás igazolja az állítást az 1 . esetben. 
2. eset. Az $O E_{2}$ és $O E_{3}$ egyenesek merólegesek (lásd az 5.8. Ábrát).
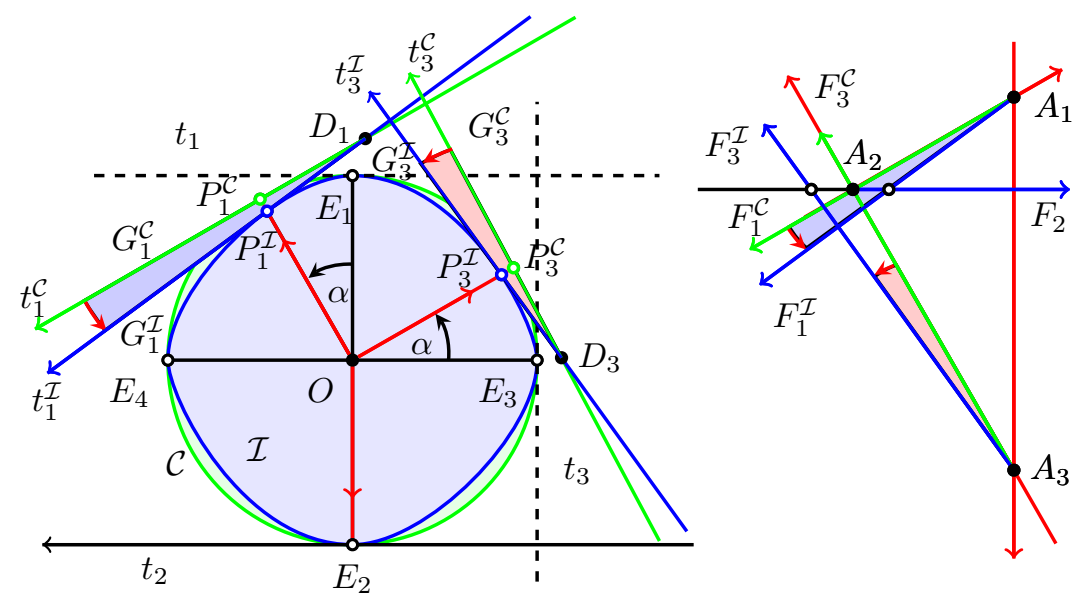

5.8. Ábra. Bal-merólegesség és magasságok, amikor $S^{\mathcal{C}}=A_{2}$.

(D3. LÉPÉS) A bizonyítást a korábbi C4-C5. lépésekkel folytathatjuk, és a C6. lépésnek a következő́k szerint módosított változatával fejezhetjük be.

Tekintsük az $\bar{A}_{1} F_{1}^{\mathcal{C}}\left\|\bar{D}_{1} G_{1}^{\mathcal{C}}, \bar{A}_{2} F_{2}\right\| t_{2}$ és $\bar{A}_{3} F_{3}^{\mathcal{C}} \| \bar{D}_{3} G_{3}^{\mathcal{C}}$ félegyeneseket. Az $A_{i} F_{i}^{\mathcal{C}}(i=1,3)$ és $A_{2} F_{2}$ egyenesek az $A_{1} A_{2} A_{3} \triangle$ derékszögû háromszög (euklideszi) magasságvonalai, tehát átmennek a trigon $A_{2}$ ortocentrumán.

Tekintsük most az $\bar{A}_{1} F_{1}^{\mathcal{I}} \| \bar{D}_{1} G_{1}^{\mathcal{I}}$ és $\bar{A}_{3} F_{3}^{\mathcal{I}} \| \bar{D}_{3} G_{3}^{\mathcal{I}}$ félegyeneseket. Az $A_{i} F_{i}^{\mathcal{I}}$ $(i=1,3)$ és $A_{2} F_{2}$ egyenesek az $A_{1} A_{2} A_{3} \triangle$ derékszögú háromszög bal-meróleges magasságvonalainak egyenesei, így a feltevés szerint át kell menniük a trigon balortocentrumán.

Ugyanakkor megvizsgálva az $\varangle\left(F_{1}^{\mathcal{C}} A_{1} F_{1}^{\mathcal{I}}\right)$ és $\varangle\left(F_{3}^{\mathcal{C}} A_{3} F_{3}^{\mathcal{I}}\right)$ irányított szögeket, azt találjuk, hogy az $\bar{A}_{1} F_{1}^{\mathcal{I}}$ és $\bar{A}_{3} F_{3}^{\mathcal{I}}$ félegyenesek az $A_{2} F_{2}$ egyeneset az $A_{2}$ pontjának különböző oldalain metszik, tehát $A_{1} F_{1}^{\mathcal{I}}, A_{2} F_{2}$ és $A_{3} F_{3}^{\mathcal{I}}$ nem mehet át egy ponton. Ez az ellentmondás igazolja a tételünket ebben az utolsó esetben.

A bizonyítás teljes. 


\section{Jelölések}

$\begin{array}{ll}A, B, C & \text { pontok } \\ l, m, n & \text { egyenesek } \\ A B & \text { a különbözó } A \text { és } B \text { pontokon átmenó egyenes } \\ A B C \triangle & \text { háromszög } A, B, C \text { csúcsokkal } \\ \mathbf{a}, \mathbf{b}, \mathbf{c} & \text { vektorok, valós } n \text {-esek } \\ \overrightarrow{A B} & \text { vektor az affin térben ( } A \text { kezdó-, } B \text { végpontú reprezentánssal) } \\ |\mathbf{a}| & \text { vektor normája, hossza, abszolút értéke } \\ \bar{A} B & \text { A kezdópontú, } B \text {-t tartalmazó félegyenes } \\ \overline{A B} & \text { nyílt szakasz } A \text { és } B \text { végpontokkal } \\ (A, B ; C) & \text { affin osztóviszony } \\ (A, B ; C)_{d} & \text { metrikus osztóviszony a } d \text { metrikával } \\ \langle A, B ; C\rangle_{d} & \text { hiperbolikus osztóviszony a } d \text { metrikával } \\ (A, B ; C, D) & \text { kettósviszony } \\ (\mathbf{a}, \mathbf{b} ; \mathbf{c}, \mathbf{d}) & \text { kettôsviszony (vektorokkal) } \\ d, d_{\mathcal{I}}, d_{\mathcal{H}} & \text { távolság (függvény) } \\ \mathbb{P}^{n}, \mathbb{R}^{n}, \mathbb{H}^{n} & n \text {-dimenziós projektív, affin, hiperbolikus tér } \\ \mathcal{D}, \mathcal{H} & \text { nyílt tartomány vagy test } \\ \partial \mathcal{D}, \partial \mathcal{H} & \text { a D és } \mathcal{H} \text { tartomány vagy test határa } \\ m \perp n & \text { merólegesség, } m \text { meróleges } n \text {-re } \\ \Phi, \Psi, \Xi & \text { terek transzformációi } \\ (\mathcal{M}, d) & \text { metrikus tér ( } \mathcal{M} \text { alaphalmaz, } d \text { metrika) } \\ \mathcal{B}^{n} & n \text {-dimenziós egységgömb } \\ \mathcal{S}^{n-1} & \end{array}$


Kozma J.

\section{Hivatkozások}

[1] D. Amir, Characterizations of Inner Product Spaces, Birkhäuser Verlag, Basel Boston - Stuttgart, 1986; doi: 10.1007/978-3-0348-5487-0. $\langle 1,9,58,61\rangle$

[2] L. Berwald, Über die n-dimensionalen Geometrien konstanter Krümmung, in denen die Geraden die kürzesten sind, Math. Z., 30 (1929), 449-469; url: http: //eudml.org/doc/168133. $\langle 20\rangle$

[3] G. Birkhoff, Orthogonality in linear metric spaces, Duke Math. J., 1 (1935), 169-172; doi: 10.1215/S0012-7094-35-00115-6. $\langle 17\rangle$

[4] W. Blaschke, Integralgeometrie 11: Zur Variationsrechnung, Abh. Math. Sem. Univ. Hamburg, 11:1(1935), 359-366; doi: 10.1007/BF02940732. 〈1〉

[5] M. R. Bridson and A. Haefliger,, Metric Spaces of Non-positive Curvature, Springer-Verlag, Berlin, (1999); doi: 10.1007/978-3-662-12494-9. $\langle 20\rangle$

[6] H. Busemann and P. J. Kelly, Projective Geometries and Projective Metrics, Academic Press, New York, 1953; url: http://store.doverpublications.com/ 0486445828.html. $\langle 18,19,20,21\rangle$

[7] H. Busemann, Recent Synthetic Differential Geometry, Springer-Verlag, New York-Heidelberg-Berlin, 1970; doi: 10.1007/978-3-642-88057-5. 〈1〉

[8] A. Cayley, A sixth Memoir upon Quantics, Philosophical Transactions of the Royal Society of London, 149 (1859), 61-90; url: https://archive.org/details/ philtrans01763152. $\langle 16\rangle$

[9] B. Colbois and C. Vernicos and P. Verovic, L'aire des triangles idéaux en géometrie de Hilbert, Enseign. Math., (2) 50 (2004), 203-237; doi: 10.5169/ seals-2649. $\langle 21\rangle$

[10] M. M. Day, Some characterizations of inner product spaces, Trans. Amer. Math.

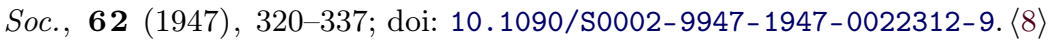

[11] M. M. DAY, Some criteria of Kasahara and Blumenthal for inner product spaces, Proceedings of Amer. Math. Soc., 10 (1959), 92-100; doi: 10.1090/ S0002-9939-1959-0106407-0. $\langle 9\rangle$

[12] N. Dunford and J. T. Shwartz, Linear Operators Part I, Wiley-Interscience, New York, 1958; url: https://isbnsearch.org/isbn/0471608483. $\langle 7\rangle$

[13] T. Foertsch and A. Karlsson, Hilbert Geometries and Minkowski norms, Journal of Geometry, 83 (2005), 22-31; doi: 10.1007/s00022-005-0005-1. $\langle 16\rangle$

[14] P. Funk, Über Flächen mit lauter geschlossenen geodätischen Linien, Mathematische Annalen, 74 (1913), 278-300; doi: 10.1007/BF01456044. $\langle 1\rangle$

[15] P. Funk, Über Geometrien, bei denen die Geraden die Kürzesten sind, Mathematische Annalen, 101 (1929), 226-237; doi: 10.1007/BF01454835. $\langle 20\rangle$

[16] P. M. Gruber, Convex and Discrete Geometry, Springer-Verlag, Berlin, 2007; doi: 10.1007/978-3-540-71133-9. $\langle 5\rangle$

[17] P. M. Gruber, John and Loewner Ellipsoids, Discrete Comp. Geom., 46 (4)(2011), 776-788; doi: 10.1007/s00454-011-9354-8. $\langle 5\rangle$ 
[18] R. Guo, A Characterization of Hyperbolic Geometry among Hilbert Geometry, Journal of Geometry, 89 (2008), 48-52; doi: 10.1007/s00022-008-1989-0.

[19] G. Hamel, Über die Geometrien, in denen die Geraden die Kürzesten sind, $M a-$ thematische Annalen, 57 (1903), 231-264; url: http://gdz.sub.uni-goettingen . $\mathrm{de} / \mathrm{dms} /$ load/img/?PID=GDZPPN002259230. $\langle 1\rangle$

[20] P. DE LA HARPE, On Hilbert's metric for simplices. In Geometric group theory, Cambridge Univ. Press, 1 (1991), 97-119; doi: 10.1017/CB09780511661860. 009. $\langle 16\rangle$

[21] M. Henk, Löwner-John Ellipsoids, Documenta Mathematica, Extra Volume ISMP, (2012), 95-106; url: http://emis.ams.org/journals/DMJDMV/vol-ismp/ 24_henk-martin.pdf. $\langle 5\rangle$

[22] D. Hilbert, Über die gerade Linie als kürzeste Verbindung zweier Punkte, $M a-$ thematische Annalen, 46 (1895), 91-96; url: http://eudml.org/doc/157750. $\langle 16\rangle$

[23] N. Ivanov, V. Arnol'd, the Jacobi identity, and orthocenters, Amer. Math. Monthly, 118 (2011), 41-65; doi: 10.4169/amer.math.monthly.118.01.041. 15$\rangle$

[24] F. John, Extremum problems with inequalities as subsidiary conditions, Studies and Essays Presented to R. Courant on his 60th Birthday, Interscience Publishers Inc. New York, (1948), 187-204; doi: 10.1007/978-3-0348-0439-4_9. 〈5〉

[25] D. C. KAY, The Ptolemaic Inequality in Hilbert Geometries, Pacific. J. Math., 21 (1967), 293-301; url: https://projecteuclid.org/euclid.pjm/1102992501. $\langle 20\rangle$

[26] P. J. Kelly and L. J. Paige, Symmetric Perpendicularity in Hilbert Geometries, Pacific J. Math., 2 (1952), 319-322; url: https://msp.org/pjm/1952/2-3/ pjm-v2-n3-p05-s.pdf. $\langle 20\rangle$

[27] Gy. Kiss and T. Szőnyi, Véges geometriák, Polygon, Szeged, (2001); url: http: //www.math.u-szeged.hu/polygon/szokis.htm. $\langle 25\rangle$

[28] F. Klein, Über die sogenannte Nicht-Euklidische Geometrie, Math. Ann., IV (1871), 573-625; doi: 10.1007/978-3-7091-9511-6_5. 〈16〉

[Km] J. Kozma, Characterization of Euclidean geometry by existence of circumcenter or orthocenter, Acta Sci. Math. (Szeged), 81:3-4 (2015), 685-698; doi: 10.14232/ actasm-015-518-0. $\langle 2,25,42,46,48,51\rangle$

[KKc] J. Kozma and Á. Kurusa, Ceva's and Menelaus' Theorems Characterize Hyperbolic Geometry Among Hilbert Geometries, Journal of Geometry, 106 (2014), 465-470; doi: 10.1007/s00022-014-0258-7. 〈2, 6, 22, 33, 34〉

[KKh] J. Kozma and Á. Kurusa, Hyperbolic is the only Hilbert geometry having circumcenter or orthocenter generally, Beiträge zur Algebra und Geometrie, 5 7:1 (2016), 243-258; doi: 10.1007/s13366-014-0233-3. 〈2, 6, 23, 25, 29, 36, 39〉

[KKp] Kurusa Á. és Kozma J, Egymásba írt háromszögek perspektivitása, Polygon, 24:1 (2016), 1-11; url: http://www.math.u-szeged.hu/polygon/polyxxiv1. pdf. $\langle 4,5,28\rangle$

[KKq] Á. Kurusa and J. Kozma, Projective metrics with quadratic hyperbolas, kézirat, (2017), pp. 21. $\langle 2,60\rangle$ 
Kozma J.

[29] Kurusa Á., Bevezetés a differenciálgeometriába, Polygon Jegyzettár 11, Polygon Kiadó, Szeged, 1999. $\langle 23\rangle$

[30] Kurusa Á., Nemeuklidészi geometriák, Polygon Jegyzettár 47, Polygon Kiadó, Szeged, 2009. $\langle 1,7,9,10,12,15\rangle$

[31] Kurusa Á., Bevezetés a geometriába, Polygon Jegyzettár 57, Polygon Kiadó, Szeged, 2015. $\langle 3,4,7\rangle$

[32] Á. Kurusa, Curvature in Hilbert-geometries, submitted (2017). 〈20, 21〉

[33] G. E. Martin, The Foundations of Geometry and the Non-Euclidean Plane, Springer Verlag, New York, 1975; doi: 10.1007/978-1-4612-5725-7. $\langle 11,12,13\rangle$

[34] R. D. Nussbaum, Hilbert's projective metric and iterated nonlinear maps, Mem. Amer. Math. Soc., 75 (1988), no. 391, iv+137 pp; doi: 10.1090/memo/0391. $\langle 16\rangle$

[35] K. Ohira, On some characterizations of abstract Euclidean spaces by properties of orthogonality, Kumamuto Jour. Sci., 1 (1952), 23-26; url: http://www.sci. kumamoto-u.ac.jp/ kjm/BKS/kjmpdf/KJSM/v1-5-ohira.pdf.

[36] A. Papadopulos and V. Troyanov, Handbook of Hilbert geometry, European Mathematical Society, Zürich (2014), ; doi: 10.4171/147. $\langle 1,58,61\rangle$

[37] A. V. Pogorelov, Hilbert's fourth problem, Winston \& Sons, Washington DC (1979), ; url: https://catalogue.nla.gov.au/Record/2596811. $\langle 1\rangle$

[38] R. Schneider, Convex bodies: the Brunn-Minkowski theory, Cambridge University Press, (1993), ; doi: 10.1017/CB09781139003858. $\langle 3\rangle$

[39] B. Segre, Ovals in a finite projective plane, Canadian J. Math., 7 (1955), 414-416; doi: $10.4153 /$ CJM-1955-045-x. $\langle 25\rangle$

[40] A. C. Thompson, Minkowski Geometry, Encylopedia of Math. and its Appl., Vol. 63, Cambridge Univ. Press, 1996; doi: 10.1017/CB09781107325845. $\langle 1,8\rangle$

[41] Z. I. Szaвó, Hilbert's fourth problem I., Adv. Math., 59 (1986), 185-301; doi: 10. 1016/0001-8708(86)90056-3. $\langle 1\rangle$

[42] C. Vernicos, On the Hilbert Geometry of Convex Polytopes. Handbook of Hilbert geometry, European Math. Society, Zürich, (2014), ; doi: 10.4171/147-1/4. 〈16〉

[43] G. Weiss, The concepts of triangle orthocenters in Minkowski planes, Journal of Geometry, 74 (2002), 145-156; doi: 0.1007/PL00012533. 


\section{Köszönetnyilvánítás}

A szerzô köszönetét fejezi ki az SZTE Bolyai Intézetének, illetôleg Doktori Iskolájának azért, hogy az elmúlt idôszakban támogatták a kutatásait. Különösen hálás kollégáinak, akik a munka végzéséhez mindig alkotó légkört teremtettek. Fontos volt a szerzốnek, hogy a kutatás folyamatában az eredményekról beszámolhasson a BME Geometria szemináriumán, a Kerékjártó Szemináriumon és a Basilicatai Egyetem Matematikai és Informatikai Tanszékének szemináriumain.

A köszönet kiemelten illeti dr. Kurusa Árpádot, aki a dolgozatban felölelt kutatási témát felvetette, a kutatások során kiváló partner és segitốkész doktori témavezetố volt.

Kozma József

Szeged, 2018. január. 5. 
Kozma J.

\section{Összefoglaló}

Az értekezésben két projektív-metrikus geometria, a Hilbert-, illetve a Minkowskiféle geometria területén folytatott azon vizsgálatainkat mutatjuk be, melyek során geometriai konfigurációkkal a hiperbolikus, illetve az euklideszi geometriát tudjuk karakterizálni.

A Minkowski-geometriákat a matematikusok jelentôs része normált vektortérként ismeri, és igen bőséges irodalom veszi számba jellemzôit és tulajdonságait [1]. A Hilbert-geometria kutatása napjainkban egyre újabb és változatosabb eredményekkel zárkózik fel [36].

Ahogyan az euklideszié a Minkowski-, a hiperbolikus geometria közvetlen általánosítása a Hilbert-geometria, melyek megismerésében elsórendú feladat az euklideszi, illetve hiperbolikus geometriában megszokott konfigurációk tulajdonságainak vizsgálata.

A kutatás általános kiindulópontja ezért az a kérdés volt, hogy egyes — más geometriákban alaposan jellemzett - konfigurációknak a Minkowski- és a Hilbertgeometriában milyen tulajdonságai vannak, illetve teljesülésük milyen további következményekkel jár? Ennek értelmében áttekintjük a vizsgált geometriák alaptulajdonságait is, így a Minkowski-geometriák mellett a hiperbolikus geometriát és a Hilbert-geometriákat is ismertetjük, majd a következô kérdéseket vizsgáljuk:

(1) Vajon az egyes konfigurációknak mely tulajdonságai maradnak meg az általános esetben, és melyek azok, amelyek tovább már nem jellemzik a konfigurációt?

(2) Milyen következménnyel jár a geometria egészére, ha egy konfiguráció valamely tulajdonságának megmaradását követeljük meg?

(3) Van-e olyan konfiguráció és annak valamilyen tulajdonsága, amely kizárja az általánosítás lehetôségét (vagyis a geometria euklideszi, illetve hiperbolikus)?

Mindegyik kérdés esetén érdekes annak felvetése is, hogy ha egy tulajdonság teljesülését nem általánosságban, hanem csak egy-két esetben írjuk elö, akkor az ugyanazt az eredményt adja-e?

Az értekezés olyan vizsgálatainkról ad képet, amelyek kivétel nélkül a klasszikus euklideszi, illetve hiperbolikus geometriák Minkowski-, illetve Hilbert-geometriák közti karakterizációjához vezetnek. ${ }^{*}$

A háromszögekkel kapcsolatos olyan ismert konfigurációkat vizsgálatunk, amelyekre vonatkozólag analóg tételek teljesülnek az euklideszi és a hiperbolikus geometriában is. Ilyenek a Ceva- és Menelaosz-tételek, amelyek automatikusan teljesülnek a Minkowski-geometriákban, és a hiperbolikus osztóviszonnyal a hiperbolikus síkon

\footnotetext{
* Az értekezésben szereplő fogalmakra, állításokra az egyszerü azonosíthatóság kedveért úgy hivatkozunk, hogy az ottani sorszámuk elé a „D:" utalást szúrjuk be.
} 
is igazolhatók (D: 2.14. Hiperbolikus Menelaosz-Tétel és D: 2.15. HiperBOLIKUS CEVA-TÉTEL), de ilyen a háromszögek magasságvonalainak, illetve oldalfelezô merôleges egyeneseinek egy nyalábhoz tartozása is (D: 2.17. HiPERBOLIKUS MAGASSÁGPONT-TÉTEL és D: 2.16. Hiperbolikus BISZEKTORÁlis CENTRUMTÉTEL). Mivel a Birkhoff-merólegességi reláció (D: 2.12. Definíció) nem szimmetrikus, külön problémaként foglalkozunk a Minkowski-, illetve a Hilbert-geometriában a háromszögek oldalfelezó merólegeseinek, illetve magasságvonalainak egy pontra illeszkedésével a Birkhoff-merólegesség (a továbbiakban bal-merólegesség), illetve annak a megkülönböztetésül jobb-merólegességnek, illetve $\mathcal{H}$-merólegességnek elnevezett inverze esetében.

Kutatásunk során fontos szerephez jutnak a szigorúan konvex tartományok körül-, illetve beírt (minimális, illetve maximális térfogatú) John-, illetve Löwnerellipszoidjai. Ezeknek a tartománnyal való érintési pontjaira vonatkozó alapvető állításokat is áttekintjük (D: 2.10. LEMMA és D: 2.11. LEMMA).

Több technikai jellegú állítás mellett egy ellipsziskarakterizációs eredményt és egy oválisokba írt háromszögekre vonatkozó Ceva-típusú tételt is igazolunk. Ezek önmagukban is érdekesek (D: 3.5. TÉTEL és D: 3.7. TÉTEL). Az ellipsziskarakterizációs eredményünk egy harmonikus elválasztásra építő jellemzés, amelynek duálisa - a Ceva- és a Menelaosz-tétel révén - ekvivalens Segre egy tételével.

A Hilbert-geometriákra vonatkozóan igazoljuk, hogy a hiperbolikus geometriát karakterizálja, ha minden trigon rendelkezik

* a Ceva-tulajdonsággal (D: 4.1. TÉTEL);

* a Menelaosz-tulajdonsággal (D: 42. TÉTEL);

* biszektorális centrummal ${ }^{12}$ (D: 43. TÉTEL);

* ortocentrummal ${ }^{13}$ (D: 4.4. TÉTEL).

Az utóbbi két állítás kapcsán utalnunk kell arra, hogy azok a D: 220. Definíció szerinti (Birkhoff-féle) merólegesség $\mathcal{H}$-merólegességnek nevezett inverzét használják, mert a Birkhoff-féle merólegesség esetében nem jutottunk eredményre, és az irodalomban sem találtunk arra vonatkozó tételt.

Minkowski-terekben igazoljuk, hogy az euklideszi geometriát karakterizálja a Minkowski-geometrián belül, ha minden trigon

* jobb-meróleges oldalfelezôi konkurensek (D: 5.1. TÉTEL);

* jobb-meróleges magasságainak egyenesei konkurensek (D: 5.2. TÉTEL);

* bal-meróleges oldalfelezói konkurensek (D: 5.3. TÉTEL);

* bal-meróleges magasságainak egyenesei konkurensek (D: 5.4. TÉTEL).

\footnotetext{
${ }^{12}$ Vagyis az oldalfelezó merólegesek egy nyalábhoz tartoznak.

${ }^{13}$ Vagyis a magasságvonalak egyenesei egy nyalábhoz tartoznak.
} 
Karakterizációs eredményeinket általában indirekt módon bizonyítjuk a Hilbert-geometriát megadó vagy a Minkowski-geometriát definiáló szigorúan konvex tartomány és a köré írt minimális térfogatú John-Löwner-ellipszoid összehasonlításával. Ennek során mindig elegendônek bizonyult (D: 2.7. LEMMA) a síkbeli esetben eljárni,vagyis egy szigorúan konvex határoló görbét és egy ellipszist összevetni e két görbe közös pontjainak száma és elrendezôdése alapján. Valójában minden esetben olyan nem elfajuló háromszöget adunk meg, mely nem teljesítheti az adott feltételeket. Emiatt bizonyos értelemben minden eredményünk tekinthetố akár ellipsziskarakterizációs tételnek is.

Végül megjegyezzük még, hogy habár az túlmutat ezen értekezés keretein, a hiperbolák esetén is választ kerestünk hasonló kérdésre: vajon egy projektív metrika klasszikus, ha benne egy metrikus hiperbola kvadratikus? A Minkowski- és a Hilbertgeometria esetében is sikerült igazolni [KKq], hogy egy hiperbola akkor és csak akkor kvadratikus, ha a geometria euklideszi, illetve Bolyai-féle hiperbolikus. 


\section{Summary}

In the dissertation, we present our research in the fields of projective metric geometries, in the course of which, we characterize the hyperbolic and Euclidean geometry among Hilbert, respectively Minkowski geometries by geometric configurations.

Most mathematicians know Minkowski geometries as normed vector spaces, and a wide literature counts their attributes and properties [1]. The research of Hilbert geometry falls into line in our days, with further various results [36].

Likewise Minkowski geometry is a straight generalisation of the Euclidean geometry, an immediate generalisation of hyperbolic geometry is Hilbert geometry. That is why investigations of properties of configurations well known from Euclidean and hyperbolic geometries is of prime importance in exploring these geometries.

Therefore, the general starting point of our dissertation was the question: what kind of properties do have some configurations - deliberately characterized in other geometries - in Minkowski and Hilbert geometries, furthermore, in case of fulfilling certain conditions, what sort of consequences shall we have take into account? Pursuant to this, a survey of the basic features of geometries under investigation is given. Beyond that of Minkowski geometries, a description of the hyperbolic and Hilbert geometries is given,

and afterwards the following questions are investigated:

(1) What properties of the particular configurations continue in the general case, and which properties will stop to characterize the configuration?

(2) What kind of consequences implies for the whole geometry if a certain property of a configuration is required to retain?

(3) Are there any configuration and a particular property of it which block the way of generalisation (i.e. the geometry will be Euclidean, respectively, hyperbolic)? In case of all questions worth to bring up the following problem: if the fulfilment of a property is not a general requirement, but holds only for some specific cases, then will it result in the same result?

The dissertation draws a picture of investigations which lead, without exception, to characterisation of classic Euclidean, respectively hyperbolic geometries among Minkowski, respectively Hilbert geometries*.

We start with investigation of some significant configurations in connection with triangles, analogous theorems about which are well known in hyperbolic geometry, as well. A proof, in the Cayley-Klein model, is shown for the hyperbolic

\footnotetext{
* For the sake of easier identification, notions and statements from the dissertation are referred so that reference „D:" is inserted before their numbers.
} 
version of the Ceva's and Menelaus' theorems (Hyperbolic Menelaus' theorem D: 2.14 and Hyperbolic Ceva's theorem D: 2.15) which automatically come true in Minkowski geometries, as well as for the statement that altitudes, respectively orthogonal bisectors of triangles belong to a bundle (THEOREM ON HYPERBolic orthocentre D: 2.17 and Theorem on HYPERBolic BiseCTORAL CENTRE D: 2.16).

As the Birkhoff-orthogonality (DEFinition D: 2.12) is not symmetric, concurrency of perpendicular bisectors and that of altitudes should be treated separately in Minkowski and Hibert geometries in the case of Birkhoff-perpendicularity (left-perpendicularity for later use), and in the case of its inverse relation, called right-perpendicularity, or $\mathcal{H}$-perpendicularity, for the sake of distinction.

In the course of our research the inscribed (maximal volume) respectively the circumscribed (minimal volume) ellipsoids (called Loewner, repsectively, John ellipsoids) of strictly convex bodies play a prominent role. Some basic statements regarding the tangent points of these ellipsoids to the convex bodies are considered: Lemma D: 2.10 and Lemma D: 2.11.

Besides several statements of technical kind, we prove a result about ellipse characterisation, and a theorem of Ceva type about inscribed triangles of ovals, which are interesting on their own, as well (Theorem D: 3.5 and Theorem D: 3.7). The ellipse characterisation is build upon harmonic division, dual of which is equivalent to - by means of Ceva's and Menelaus' theorem - a theorem of Segre.

With respect to Hilbert geometries is proven that hiperbolic geometry is characterized by the property that every trigon possesses

* the Ceva property (Theorem D: 4.1);

* the Menelaus property (Theorem D: 42);

$\star$ a bisectoral centre ${ }^{14}$. (THEOREM D: 43);

$\star$ an orthocentre ${ }^{15}$ (TheOREM D: 44).

As regards latter two statements, we have to mention that they apply the inverse of the Birkhoff-perpendicularity, called $\mathcal{H}$-perpendicularity, (Definition D: 220) as we could not achieve any result in the case of Birkhoff-perpendicularity, and we could not find any reference to a result of that kind in the literature.

In Minkowski spaces, it is proven equally for the case of the left- and the right-perpendicularity that the Euclidean geometry is characterised by the property that every trigon possesses

$\star$ the right-bisectoral centre (THEOREM D: 5.1);

* the right-orthocentre (THEOREM D: 52);

\footnotetext{
${ }^{14}$ I.e., perpendicular bisectors belong to a bundle.

${ }^{15}$ I.e., altitudes belong to a bundle.
} 
* the left-bisectoral centre (THEOREM D: 53);

* the left-orthocentre (THEOREM D: 5.4).

In our indirect proofs the defining strictly convex bodies of the Hilbert- or Minkowski-geometries and their circumscribed minimal volume John-Löwner ellipsoids are compared. The demonstrations can be restricted to the (two dimensional) planar case (Lемma D: 2.7), that is, to a strictly convex curve and an ellipse. We suppose that they do not coincide, and in each case, according to the number and the arrangement of the common points of the two borders, we look for such a non-degenerate triangle that can not fulfill the given assumption. That is why our results can be considered ellipse characterisation theorems with good reason too.

Finally, albeit it outreaches the subject of our dissertation, we notice that we have considered similar question for hyperbolas: Is a projective metric a classic one if a hyperbola is quadratic in it? We could prove, in the case of the Minkowski and the Hilbert geometries equally, that a hyperbola is quadratic if and only if the geometry is a Euclidean, respectively, a hyperbolic geometry. 